\title{
UNIFORMAT II Elemental Classification for Building Specifications, Cost Estimating, and Cost Analysis
}

Robert P. Charette Harold E. Marshall

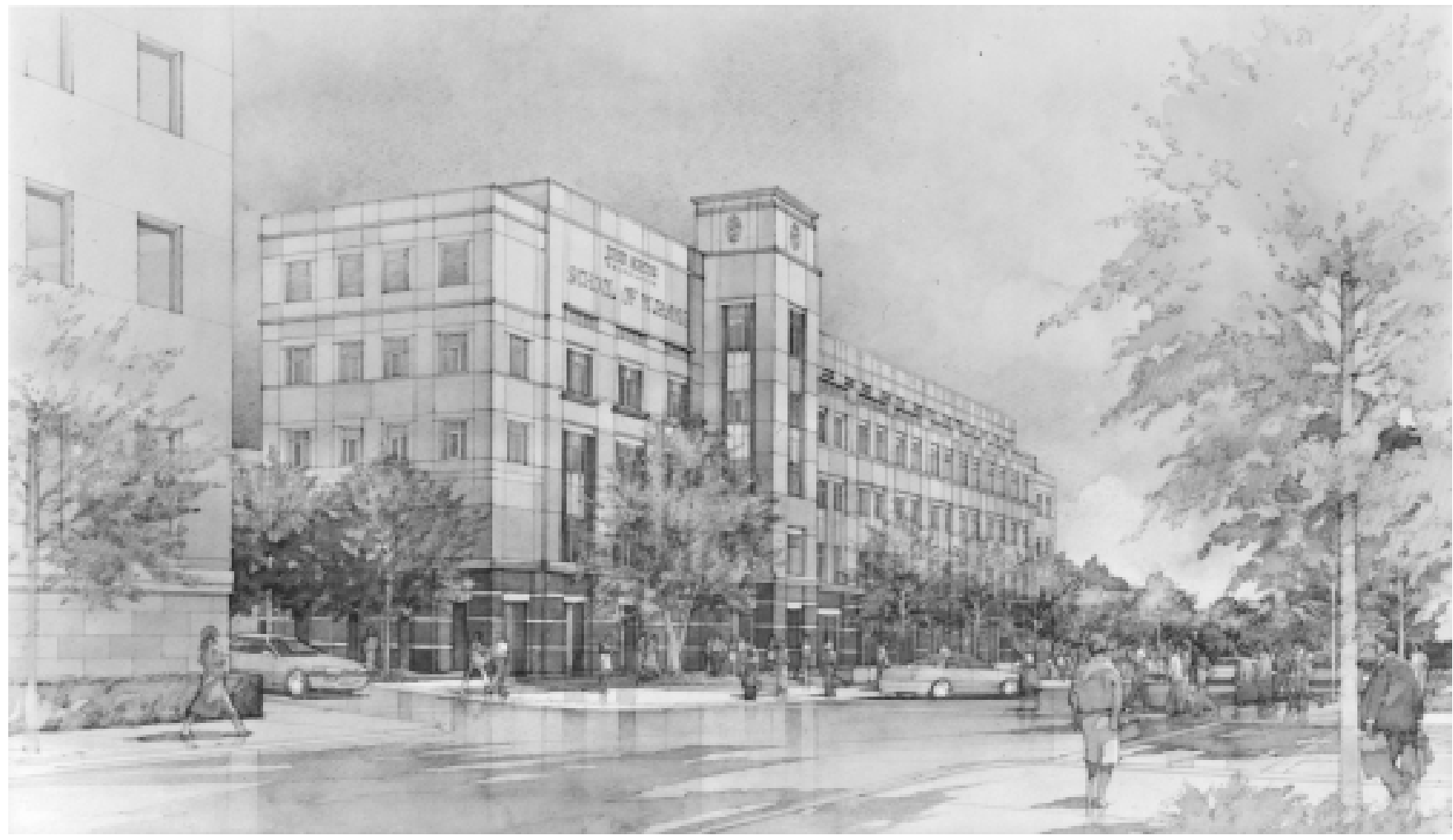


ASTM Uniformat II Classification for Building Elements (E1557-97)

\begin{tabular}{|c|c|c|}
\hline $\begin{array}{c}\text { Level 1 } \\
\text { Major Group Elements }\end{array}$ & $\begin{array}{c}\text { Level } 2 \\
\text { Group Elements }\end{array}$ & $\begin{array}{c}\text { Level } 3 \\
\text { Individual Elements }\end{array}$ \\
\hline \multirow[t]{2}{*}{ A SUBSTRUCTURE } & A10 Foundations & $\begin{array}{ll}\text { A1010 } & \text { Standard Foundations } \\
\text { A1020 } & \text { Special Foundations } \\
\text { A1030 } & \text { Slab on Grade } \\
\end{array}$ \\
\hline & A20 $\quad$ Basement Construction & $\begin{array}{ll}\text { A2010 } & \text { Basement Excavation } \\
\text { A2020 } & \text { Basement Walls }\end{array}$ \\
\hline \multirow[t]{3}{*}{ B SHELL } & B10 $\quad$ Superstructure & $\begin{array}{ll}\text { B1010 } & \text { Floor Construction } \\
\text { B1020 } & \text { Roof Construction }\end{array}$ \\
\hline & B20 Exterior Enclosure & $\begin{array}{ll}\text { B2010 } & \text { Exterior Walls } \\
\text { B2020 } & \text { Exterior Windows } \\
\text { B2030 } & \text { Exterior Doors }\end{array}$ \\
\hline & B30 $\quad$ Roofing & $\begin{array}{ll}\text { B3010 } & \text { Roof Coverings } \\
\text { B3020 } & \text { Roof Openings } \\
\end{array}$ \\
\hline \multirow[t]{3}{*}{$\begin{array}{ll}\text { C } & \text { INTERIORS }\end{array}$} & C10 Interior Construction & $\begin{array}{ll}\text { C1010 } & \text { Partitions } \\
\text { C1020 } & \text { Interior Doors } \\
\text { C1030 } & \text { Fittings } \\
\end{array}$ \\
\hline & C20 $\quad$ Stairs & $\begin{array}{ll}\text { C2010 } & \text { Stair Construction } \\
\text { C2020 } & \text { Stair Finishes }\end{array}$ \\
\hline & C30 Interior Finishes & $\begin{array}{ll}\text { C3010 } & \text { Wall Finishes } \\
\text { C3020 } & \text { Floor Finishes } \\
\text { C3030 } & \text { Ceiling Finishes }\end{array}$ \\
\hline \multirow[t]{5}{*}{ D $\quad$ SERVICES } & D10 $\quad$ Conveying & $\begin{array}{ll}\text { D1010 } & \text { Elevators \& Lifts } \\
\text { D1020 } & \text { Escalators \& Moving Walks } \\
\text { D1090 } & \text { Other Conveying Systems }\end{array}$ \\
\hline & D20 $\quad$ Plumbing & $\begin{array}{ll}\text { D2010 } & \text { Plumbing Fixtures } \\
\text { D2020 } & \text { Domestic Water Distribution } \\
\text { D2030 } & \text { Sanitary Waste } \\
\text { D2040 } & \text { Rain Water Drainage } \\
\text { D2090 } & \text { Other Plumbing Systems }\end{array}$ \\
\hline & D30 HVAC & $\begin{array}{ll}\text { D3010 } & \text { Energy Supply } \\
\text { D3020 } & \text { Heat Generating Systems } \\
\text { D3030 } & \text { Cooling Generating Systems } \\
\text { D3040 } & \text { Distribution Systems } \\
\text { D3050 } & \text { Terminal \& Package Units } \\
\text { D3060 } & \text { Controls \& Instrumentation } \\
\text { D3070 } & \text { Systems Testing \& Balancing } \\
\text { D3090 } & \text { Other HVAC Systems \& } \\
& \text { Equipment } \\
\end{array}$ \\
\hline & D40 Fire Protection & $\begin{array}{ll}\text { D4010 } & \text { Sprinklers } \\
\text { D4020 } & \text { Standpipes } \\
\text { D4030 } & \text { Fire Protection Specialties } \\
\text { D4090 } & \text { Other Fire Protection Systems } \\
\end{array}$ \\
\hline & D50 $\quad$ Electrical & $\begin{array}{ll}\text { D5010 } & \text { Electrical Service \& } \\
& \text { Distribution } \\
\text { D5020 } & \text { Lighting and Branch Wiring } \\
\text { D5030 } & \text { Communications \& Security } \\
\text { D5090 } & \text { Other Electrical Systems } \\
\end{array}$ \\
\hline \multirow[t]{2}{*}{$\begin{array}{cc}\text { E } & \text { EQUIPMENT \& } \\
& \text { FURNISHINGS }\end{array}$} & $\begin{array}{ll}\text { E10 } & \text { Equipment }\end{array}$ & $\begin{array}{ll}\text { E1010 } & \text { Commercial Equipment } \\
\text { E1020 } & \text { Institutional Equipment } \\
\text { E1030 } & \text { Vehicular Equipment } \\
\text { E1090 } & \text { Other Equipment } \\
\end{array}$ \\
\hline & E20 Furnishings & $\begin{array}{ll}\text { E2010 } & \text { Fixed Furnishings } \\
\text { E2020 } & \text { Movable Furnishings } \\
\end{array}$ \\
\hline \multirow[t]{2}{*}{$\begin{array}{l}\mathrm{F} \text { SPECIAL CONSTRUCTION } \\
\& \text { DEMOLITION }\end{array}$} & F10 Special Construction & $\begin{array}{ll}\text { F1010 } & \text { Special Structures } \\
\text { F1020 } & \text { Integrated Construction } \\
\text { F1030 } & \text { Special Construction Systems } \\
\text { F1040 } & \text { Special Facilities } \\
\text { F1050 } & \text { Special Controls and } \\
& \text { Instrumentation } \\
\end{array}$ \\
\hline & $\begin{array}{ll}\text { F20 } & \text { Selective Building } \\
& \text { Demolition }\end{array}$ & $\begin{array}{ll}\text { F2010 } & \text { Building Elements Demolition } \\
\text { F2020 } & \text { Hazardous Components } \\
& \text { Abatement } \\
\end{array}$ \\
\hline
\end{tabular}




\section{UNIFORMAT II Elemental Classification for Building Specifications, Cost Estimating, and Cost Analysis}

Robert P. Charette

Concordia University

Montreal, Canada

and

Harold E. Marshall

Office of Applied Economics

Building and Fire Research Laboratory

National Institute of Standards and Technology

\section{October 1999}

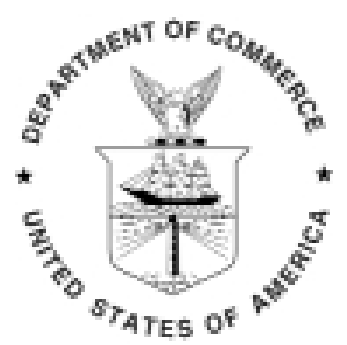

U.S. DEPARTMENT OF COMMERCE

William M. Daley, Secretary

Technology Administration

Cheryl L. Shavers, Under Secretary for Technology

National Institute of Standards and Technology

Raymond G. Kammer, Director 



\begin{abstract}
This report describes UNIFORMAT II, a format for classifying building elements and related sitework. Elements, as defined here, are major components common to most buildings. Elements usually perform a given function, regardless of the design specification, construction method, or materials used. Using UNIFORMAT II ensures consistency in the economic evaluation of building projects over time and from project to project, and it enhances project management and reporting at all stages of the building life cycle_planning, programming, design, construction, operations, and disposal. UNIFORMAT II is a significant advance over the original UNIFORMAT classification in that it has added elements and expanded descriptions of many existing elements. This report proposes a fourth level of definition to augment the three hierarchical levels provided in the original UNIFORMAT II. Starting from Level 1, the largest element grouping, it identifies Major Group Elements such as the Substructure, Shell, and Interiors. Level 2 subdivides Level 1 elements into Group Elements. The Shell, for example, includes the Superstructure, Exterior Closure, and Roofing. Level 3 breaks the Group Elements further into Individual Elements. Exterior Closure, for example, includes Exterior Walls, Exterior Windows, and Exterior Doors. The proposed Level 4 breaks the individual elements into yet smaller sub-elements. Standard Foundation subelements, for example, include wall foundations, column foundations, perimeter drainage, and insulation. A major benefit of performing an economic analysis based on an elemental framework instead of on a product-based classification is the reduction in time and costs for evaluating alternatives at the early design stage. This encourages more economic analyses and more economically efficient choices among buildings and building elements. Other UNIFORMAT II benefits include providing a standardized format for collecting and analyzing historical data to use in estimating and budgeting future projects; providing a checklist for the cost estimation process as well as the creativity phase of the value engineering job plan; providing a basis for training in cost estimation; facilitating communications among members of a project team regarding the scope of work and costs in each discipline; and establishing a database for automated cost estimating. This report focuses on the benefits of applying UNIFORMAT II in design specifications, cost estimating, and cost analysis. A proposed summary sheet for presenting building and sitework elemental costs with cost analysis parameters provides an efficient tool for communicating economic information to decision makers in a quickly understood, concise format that helps them make project choices. Owners, developers, programmers, cost planners, project managers, schedulers, architects and engineers, operating and maintenance staff, manufacturers, specification writers, and educators will find the classification useful.
\end{abstract}




\section{Preface}

This is the seventh in a series of National Institute of Standards and Technology (NIST) reports on recommended standards related to applying economic evaluation methods to building decisions. ${ }^{1}$ The first four dealt with the theory and application of economic methods of analysis, including life-cycle costing, net benefits, benefit-to-cost and savings-to-investment ratios, internal rate of return, and payback. These reports were used as the bases for standard practices published by the American Society for Testing and Materials (ASTM). The fifth NIST report was a recommended guide that focused on techniques that account for uncertainty in project input values and techniques that measure the risk that a project will have a less favorable economic outcome than what is desired or expected. ASTM used it as the basis for a standard guide for selecting among techniques for handling uncertainty and risk in project evaluation. The sixth NIST report was a recommended classification of building elements, UNIFORMAT II, for ensuring consistency in the format used for reporting the economic evaluation of projects over time and from project to project. ASTM used the report as the basis for a standard classification of building and site-related elements.

This report differs from the 1992 NIST UNIFORMAT II report in four ways. First, it provides for all elements alphanumeric designators that conform to those of the ASTM UNIFORMAT II standard. Second, it adds to the classification a fourth level of subelements. Third, it provides more explanations and illustrations of applications of UNIFORMAT II, with a focus on design specification, cost estimates, and cost analysis. Fourth, it introduces a standardized elemental cost summary format that helps users present their estimates in a way that is concise, consistent, easily understood, and adapted to design cost analysis.

The report supports ongoing standards development activities by ASTM's Building Economics Subcommittee (E06.81) and is in response to requests from the building community for a fourth hierarchical level of building elements. The report will be proposed as the technical basis for revisions to the existing ASTM standard classification for elements of buildings and related sitework. It will complement the existing set of ASTM practices, guides, and adjuncts by providing a more detailed and improved

\footnotetext{
${ }^{1}$ The previous six reports are as follows: Rosalie T. Ruegg, Stephen R. Petersen, and Harold E. Marshall, Recommended Practice for Measuring Life-Cycle Costs of Buildings and Building Systems, National Bureau of Standards Interagency Report 80-2040, June 1980; Harold E. Marshall and Rosalie T. Ruegg, Recommended Practice for Measuring Net Benefits and Internal Rates of Return for Investments in Buildings and Building Systems, National Bureau of Standards Interagency Report 83-2657, October 1983; Harold E. Marshall and Rosalie T. Ruegg, Benefit/Cost and Savings-to-Investment Ratios for Buildings and Building Systems, National Bureau of Standards Interagency Report 81-2397, November 1981; Harold E. Marshall, Recommended Practice for Measuring Simple and Discounted Payback for Investments in Buildings and Building Systems, National Bureau of Standards Interagency Report 84-2850, March 1984; Harold E. Marshall, Techniques for Treating Uncertainty and Risk in the Economic Evaluation of Building Investments, National Institute of Standards and Technology Special Publication 757, September 1988, and Brian Bowen, Robert P. Charette, and Harold E. Marshall, UNIFORMAT II: A Recommended Classification for Building Elements and Related Sitework, National Institute of Standards and Technology Special Publication 841, August 1992.
} 
classification for collecting and evaluating costs in the economic evaluation of buildings and building systems. The report's format for presenting an elemental cost summary will be proposed as the basis of a new ASTM standard classification for elemental cost summaries.

Note: The policy of the National Institute of Standards and Technology is to use the International System of Units (SI) for all measurements in its publications. However, in the construction and construction materials industries in North America, certain non-SI units are so widely used that it is more practical and less confusing to include measurement values for customary units only in the document. For example, much of the tabular material in the report comes from cost estimating guides, which use customary units. The appendix entitled "Symbols" lists all of the measurement symbols and their meanings as used in the report.

Disclaimer: Certain trade names and company products are mentioned in the text or identified in an illustration in order to adequately specify the experimental procedure and equipment used. In no case does such an identification imply recommendation or endorsement by the National Institute of Standards and Technology, nor does it imply that the products are necessarily the best available for the purpose. 


\section{Acknowledgments}

Thanks are due to the ASTM members and others who participated in the discussions of an improved UNIFORMAT II for building elements and thereby helped determine the framework of this report. Technical support from professional societies and the public and private sectors contributed to arriving at a consensus for the new fourth level of classification. Special appreciation is extended to Brian Bowen, President of Hanscomb, Inc., for his contribution to the development of the Level 4 UNIFORMAT II; to Robert Chapman of NIST for his technical contributions; to Sandra Kelley and Cathy Linthicum for their typing and preparation of the document for printing; and to Amy Boyles for her assistance in computer formatting of tables. Thanks are also due to John Ferguson, R.S. Means Co., Inc., for his help in identifying appropriate costs for inclusion in the charts and tables, and to Ayers Saint Gross, Architects and Planners, for the cover artwork of the Johns Hopkins University School of Nursing. 


\section{Table of Contents}

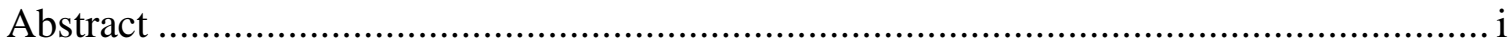

Preface

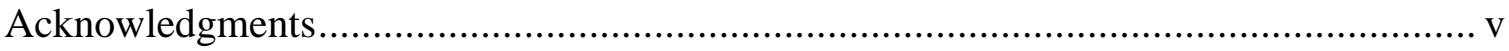

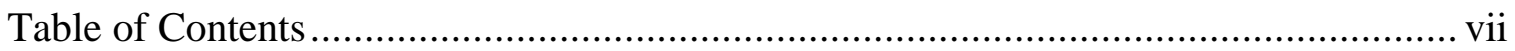

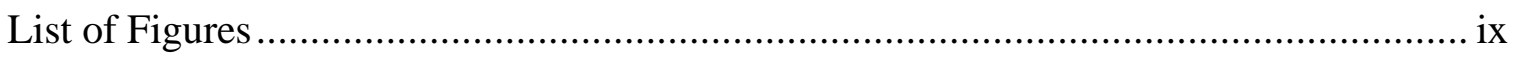

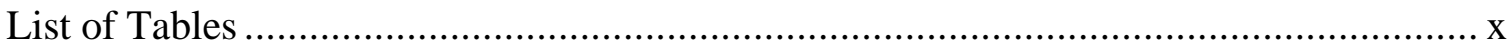

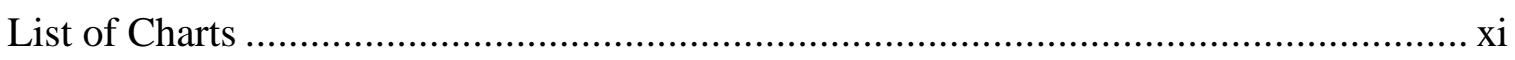

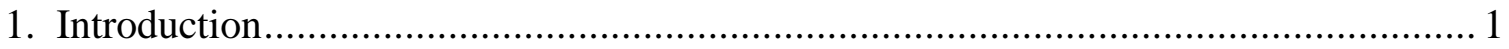

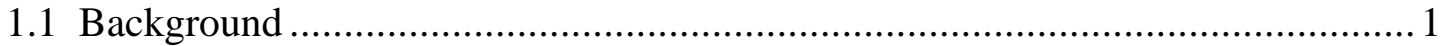

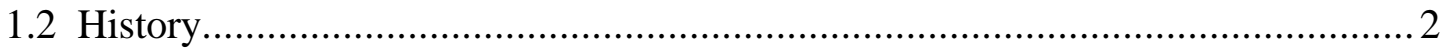

1.3 Purpose and Benefits .............................................................................. 3

1.4 The Building Life Cycle …………...........................................................

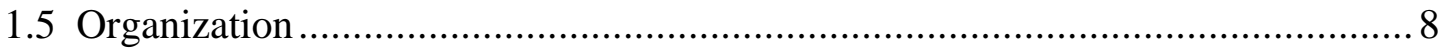

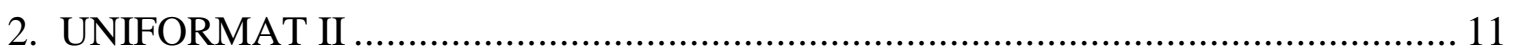

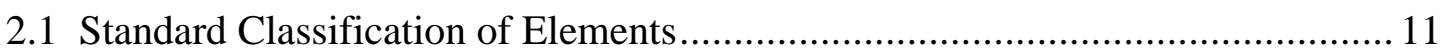

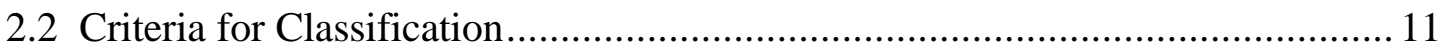

2.3 The Relationship of UNIFORMAT II to Other Elemental Classifications .......... 13

2.4 Additional Levels of Definition ............................................................... 14

3. Applying UNIFORMAT II For Specifications .................................................... 15

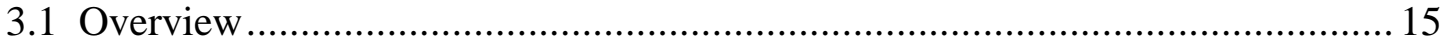

3.2 Performance Specifications......................................................................... 17

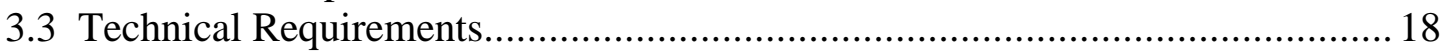

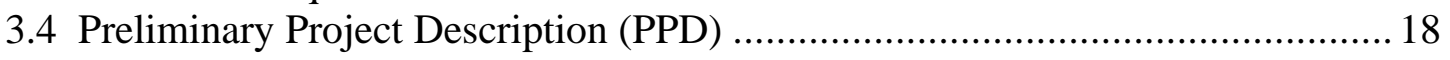

4. UNIFORMAT II For Elemental Estimates and Design Cost Analysis ........................2 23

4.1 Overview of Design and Construction Cost Estimates.................................... 23

4.2 Benefits of Elemental Design Estimates.......................................................2

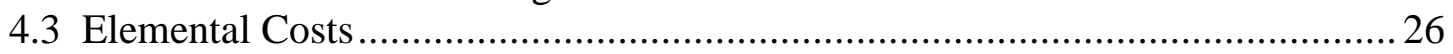

4.3.1 Unit Rates and Quantities ................................................................ 27

4.3.2 Assembly Costs ............................................................................. 28

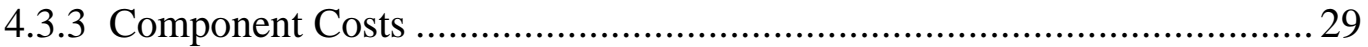

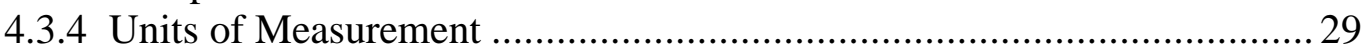

4.4 Cost Analysis Parameters .......................................................................... 31

4.5 Elemental Cost Estimate Summary Format and Case Illustration ...................... 31 


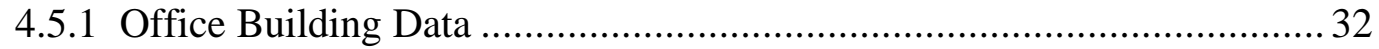

4.5.2 Elemental Estimate Cost Summaries................................................. 34

4.5.3 Allowances, Overhead, and Profit..................................................... 34

4.5.4 Detailed Elemental Cost Estimates .................................................. 35

4.6 Converting UNIFORMAT II Estimates to MasterFormat $95^{\mathrm{TM}} \ldots \ldots \ldots \ldots \ldots \ldots . . . . . . . . . . . .46$

4.7 Sources of Elemental Cost, Engineering, and Design Data............................. 46

4.7.1 Elemental Cost Data ........................................................................... 46

4.7.2 Engineering and Design Data ..................................................... 48

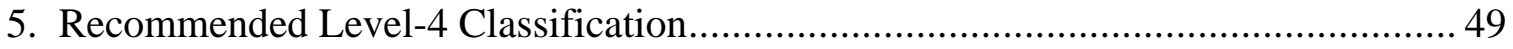

6. Summary and Suggestions for Further Work …........................................... 55

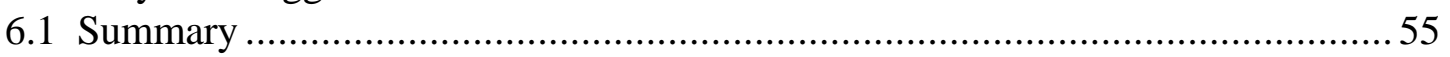

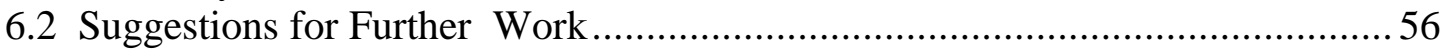

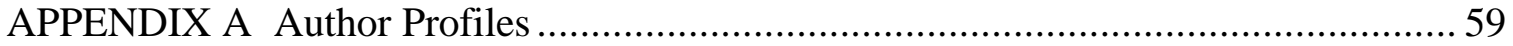

APPENDIX B UNIFORMAT II, Level-3 ELEMENT DESCRIPTIONS—List of Inclusions and Exclusions........................................................................ 61

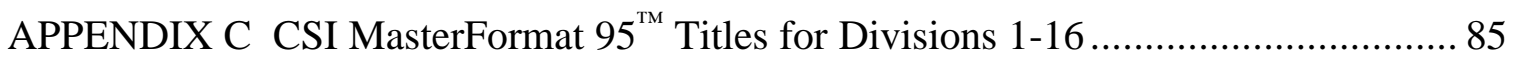

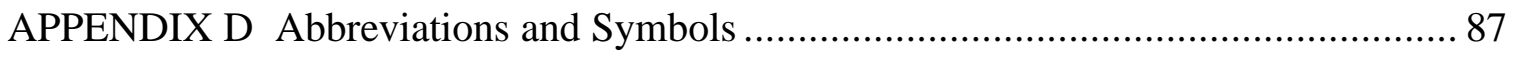

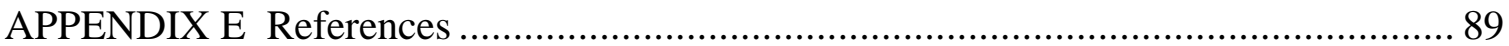




\section{List of Figures}

Figure 1.1 Five Phases of the Building Life Cycle ............................................... 6

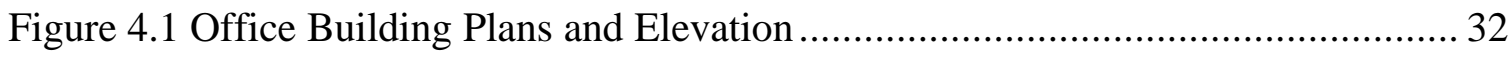

Figure 6.1 Framework of the Built Environment .................................................. 57 


\section{List of Tables}

Table 4.1 B2010 Exterior Walls—Quality Levels and Unit Costs............................ 26

Table 4.2 Assembly Costs for Floor Construction, Element B1010.......................... 28

Table 4.3 UNIFORMAT II Building Elemental Cost Summary for Buildings .............. 36

Table 4.4 UNIFORMAT II Elemental Cost Summary for Sitework............................ 37

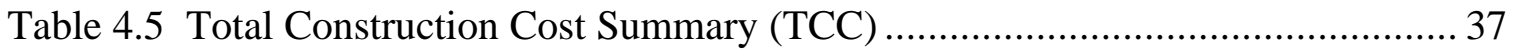

Table 4.6 Detailed Elemental Cost Estimates for Buildings ................................... 38

Table 4.7 Detailed Elemental Cost Estimates for Sitework ....................................... 43

Table 4.8 Elemental Cost Calculations for Element A1010, Standard

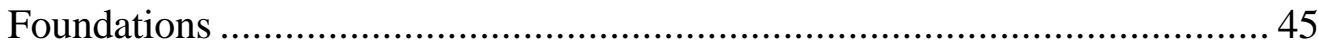




\section{List of Charts}

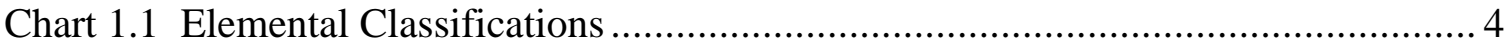

Chart 2.1 ASTM UNIFORMAT II Classification for Building Elements (E1557-97) ... 12

Chart 2.2 ASTM UNIFORMAT II Classification for Building-Related Sitework

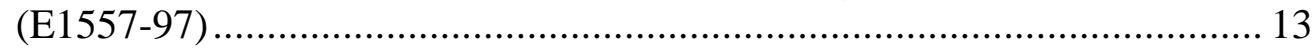

Chart 3.1 Program and Design Specifications ......................................................... 16

Chart 3.2 Performance and Descriptive Specifications For Element B3010, Roof

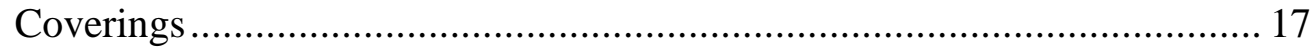

Chart 3.3 Examples of UNIFORMAT II Used in Presenting Technical Program Requirements ....................................................................................... 19

Chart 3.4 Preliminary Project Description (PPD) ................................................... 20

Chart 4.1 UNIFORMAT II Links Elemental Preliminary Project Descriptions and Design Cost Estimates .............................................................................. 24

Chart 4.2 Unit Rates for Brick Face Composite Wall, Element B2010 ......................... 27

Chart 4.3 Component Costs for Element D3020, 100 MBH Heat Generating System ... 30

Chart 4.4 UNIFORMAT II Elemental Project Description (Level 2) - 8 Storey

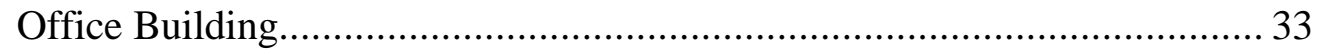

Chart 4.5 Relationship of UNIFORMAT to MasterFormat ${ }^{\mathrm{TM}}$..................................... 47

Chart 5.1 Suggested Level 4 for the UNIFORMAT II Classification of Building Elements

Chart 5.2 Suggested Level 4 for the UNIFORMAT II Classification of BuildingRelated Sitework 53 


\section{Introduction}

\subsection{Background $^{2}$}

The building community needs a classification framework to provide a consistent reference for the description, economic analysis, and management of buildings during all phases of their life cycle. This includes planning, programming, design, construction, operations, and disposal. The elemental building classification UNIFORMAT II meets these objectives. Elements are major components, common to most buildings, that usually perform a given function regardless of the design specification, construction method, or materials used. Examples of elements are foundations, exterior walls, sprinkler systems, and lighting.

The need for an elemental classification is most apparent in the economic evaluation of building alternatives at the design stage. One way of obtaining an estimate of the lifecycle costs of design alternatives is to perform detailed quantity takeoffs of all materials and tasks associated with the construction, operation, and maintenance of the buildings. MasterFormat $95^{\mathrm{TM}},{ }^{3}$ a classification that is based on products and materials, is a logical format choice when preparing detailed cost estimates. But a cost estimate prepared using a format based on a listing of products and materials is time consuming, costly, and inappropriate at the early design stages. Yet, it is in the early stages of design that economic analysis is most important in establishing the economically efficient choices among building alternatives. Only estimates based on an elemental classification such as UNIFORMAT II provide the necessary cost information for the analyst to evaluate building alternatives in a cost-effective manner.

UNIFORMAT II is the elemental classification proposed in this report because it was developed through an industry/government consensus process and has been widely accepted as an ASTM standard. ${ }^{4}$ A "standard" set of elements that are uniformly applied is essential to achieve the benefits of the elemental system approach. Shared databases of historical elemental costs, for example, are of little help in estimating future costs unless the user defines elements the same as the categories in the database.

\footnotetext{
${ }^{2}$ For additional background information, see Bowen, Charette, and Marshall, UNIFORMAT II, NIST Special Publication 841.

${ }^{3}$ The Construction Specifications Institute, MasterFormat 95 Construction Specifications Institute, 1995).

${ }^{4}$ American Society for Testing and Materials, ASTM E 1557-97: "Standard Classification for Building Elements and Related Sitework-UNIFORMAT II" (West Conshohocken, PA: American Society for Testing and Materials, 1997).
} 


\subsection{History}

Hanscomb Associates in the United States developed for the American Institute of Architects (AIA) in 1973 an elemental format called MASTERCOST. ${ }^{5}$ The General Services Administration (GSA) was also developing an elemental format, which was called UNIFORMAT. AIA and GSA ultimately agreed on a common format which became known officially as UNIFORMAT. It was incorporated into AIA's practice on construction cost management ${ }^{6}$ and GSA's project estimating requirements.

UNIFORMAT never gained "standard" status or Federal recognition as an official elemental classification. Yet, it is the basis of most elemental formats used in the United States.

In 1989, the E06.81 ASTM Subcommittee on Building Economics, representing a wide spectrum of the construction industry, initiated the development of an ASTM Standard Classification for Building Elements based in part on the original UNIFORMAT. The new classification was called UNIFORMAT II to emphasize its ties to the original UNIFORMAT.

In August of 1992, NIST issued Special Publication 841 entitled UNIFORMAT II - A Recommended Classification for Building Elements and Related Sitework. ${ }^{8}$ The purpose of the publication was to obtain consensus from the design and construction industry in preparation for writing an ASTM standard on UNIFORMAT II. ASTM Standard E1557, "Standard Classification for Building Elements and Related Sitework-UNIFORMAT II," approved in 1993, was the result. The standard was revised in 1997 and designated as E1557-97. ${ }^{9}$

UNIFORMAT II provides significant advances over the original UNIFORMAT produced for GSA and AIA. UNIFORMAT II takes into consideration a broader range of building types than those originally considered, and numerous suggestions for improvement made by practitioners using the original UNIFORMAT were incorporated. These included suggestions of the United States defense agencies that were also using variants of UNIFORMAT.

Elemental formats were developed in other countries prior to UNIFORMAT in a search for a better framework to help perform economic analyses of building projects. British quantity surveyors first developed an elemental format after World War II while helping the Department of Education develop a cost planning and cost control approach in

\footnotetext{
${ }^{5}$ American Institute of Architects, MASTERCOST Instruction Manual (Washington, DC: American Institute of Architects, 1974).

${ }^{6}$ American Institute of Architects, "Practice 3.73-Construction Cost Management," The Architects Handbook of Professional Practice $-7^{\text {th }}$ Edition (Washington, DC: American Institute of Architects, 1992), pp. 681-702.

${ }^{7}$ General Services Administration, Handbook PBS P3440.5, Project Estimating Requirements

(Washington, DC: General Services Administration, August 24, 1981).

${ }^{8}$ Bowen, Charette, and Marshall, UNIFORMAT II, NIST Special Publication 841.

${ }^{9}$ ASTM Standard E 1557-97: "Standard Classification for Building Elements and Related Sitework."
} 
rebuilding and expanding the British school system. ${ }^{10}$ This led to the Royal Institution of Chartered Surveyors (RICS) publishing a standard list of elements ${ }^{11}$ in 1969 that the building community uses routinely in the United Kingdom. As quantity surveyors who trained in Britain performed their jobs around the globe, they took the elemental format with them. By 1972, the Canadian Institute of Quantity Surveyors promulgated its own standard classification of elements for buildings ${ }^{12}$ which was subsequently adopted by the Royal Architectural Institute of Canada (RAIC). The United Kingdom, Belgium,

Germany, France, Ireland, Switzerland, Denmark, South Africa, Japan, the Netherlands, Hong Kong, and many of the former British colonies now have an elemental classification system. The need for a universal elemental system has encouraged the International Council for Building Research Studies and Documentation (CIB) and the Construction Economics European Committee (CEEC) to establish an elemental format to collect costs for international exchange. A major objective of the CEEC format is to make it compatible with the existing formats of as many European countries as possible. However, the CEEC format has not been widely adopted.

Chart 1.1 summarizes the four elemental classifications referred to earlier UNIFORMAT, sponsored by GSA and AIA, variants of which are used informally in the United States; the Canadian CIQS classification; the United Kingdom RICS classification, and the European CEEC classification for data exchange.

\subsection{Purpose and Benefits}

There are three purposes of this report: (1) to expand the classification to a fourth level of definition which would form the basis for revising and expanding the UNIFORMAT II ASTM standard, E1557-97; (2) to describe several applications of the UNIFORMAT II classification and the benefits of its use over the phases of a building project's life cycle, with particular emphasis on specifications and estimates during programming and design; and (3) to recommend a standard format for summarizing an elemental cost estimate using UNIFORMAT II.

The prime benefit of applying UNIFORMAT II as described in this report is to increase efficiency in carrying out each phase of the building life cycle defined in section 1.4. Applying UNIFORMAT II at each step of the building process provides significant savings to industry. Data entered in a consistent format will not have to be reentered at subsequent phases of the building life cycle. Users will understand and be able to compare information at every phase because it is linked to a common, uniform, standardized, elemental classification structure. Better information, generated at less

\footnotetext{
${ }^{10}$ For a history of the quantity surveying profession in the United Kingdom, see Nisbet, James, Called to Account-Quantity Surveying 1936-1986 (London, England: Stokes Publications, 1989).

${ }^{11}$ Royal Institution of Chartered Surveyors (RICS), Standard Form of Cost Analysis (London, England: The Building Cost Information Service, 1969 (reprinted December 1987).

${ }^{12}$ Canadian Institute of Quantity Surveyors, Elemental Cost Analysis-Method of Measurement and Pricing (Toronto, Ontario, Canada: Canadian Institute of Quantity Surveyors, first issued 1972, revised 1990).
} 


\section{Chart 1.1 Elemental Classifications}

\begin{tabular}{|c|c|c|c|}
\hline $\begin{array}{c}\text { UNIFORMAT } \\
\text { General Services Administration (GSA) }\end{array}$ & $\begin{array}{c}\text { CANADIAN INSTITUTE OF QUANTITY } \\
\text { SURVEYORS (CIQS) }\end{array}$ & $\begin{array}{c}\text { THE ROYAL INSTITUTION OF CHARTERED } \\
\text { SURVEYORS (RICS-UK) }\end{array}$ & $\begin{array}{c}\text { CONSTRUCTION ECONOMICS EUROPEAN } \\
\text { COMMITTEE (CEEC) }\end{array}$ \\
\hline 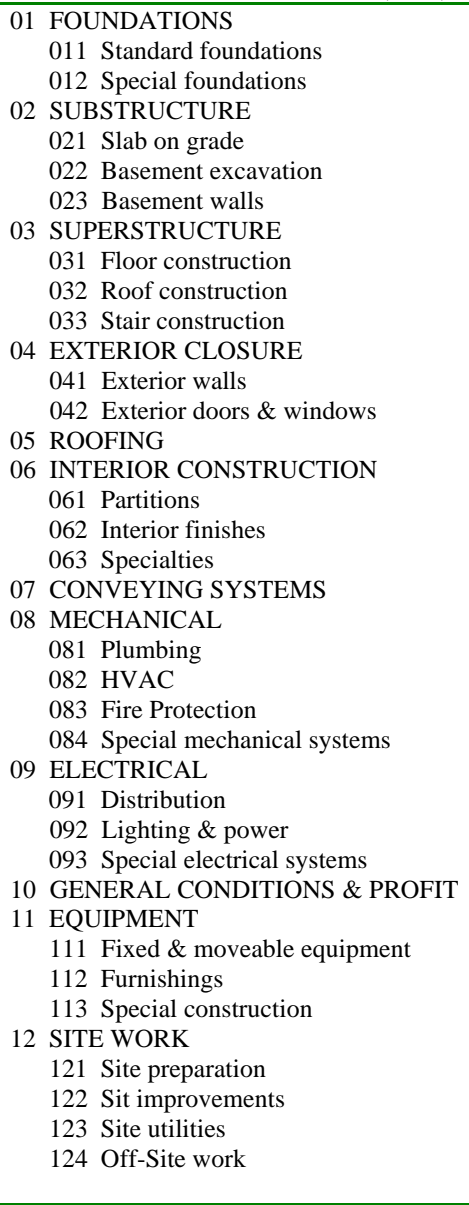 & $\begin{array}{l}\text { A1 SUBSTRUCTURE } \\
\text { A11 Foundations } \\
\text { A12 Basement excavation } \\
\text { A2 STRUCTURE } \\
\text { A21 Lowest floor construction } \\
\text { A22 Upper floor construction } \\
\text { A23 Roof construction } \\
\text { A3 EXTERIOR ENCLOSURE } \\
\text { A31 Walls below grade } \\
\text { A32 Walls above grade } \\
\text { A33 Windows \& entrances } \\
\text { A34 Roof covering } \\
\text { A35 Projections } \\
\text { B1 PARTITIONS \& DOORS } \\
\text { B11 Partitions } \\
\text { B12 Doors } \\
\text { B2 FINISHES } \\
\text { B21 Floor finishes } \\
\text { B22 Ceiling finishes } \\
\text { B23 Wall finishes } \\
\text { B3 FITTINGS \& EQUIPMENT } \\
\text { B31 Fittings \& equipment } \\
\text { B32 Equipment } \\
\text { B33 Conveying systems } \\
\text { C1 MECHANICAL } \\
\text { C11 Plumbing \& drainage } \\
\text { C12 Fire protection } \\
\text { C13 HVAC } \\
\text { C14 Controls } \\
\text { C2 ELECTRICAL } \\
\text { C21 Services \& distribution } \\
\text { C22 Lighting, devices \& heating } \\
\text { C23 Systems \& ancillaries } \\
\text { D1 SITE WORK } \\
\text { D11 Site development } \\
\text { D12 Mechanical site services } \\
\text { D13 Electrical site services } \\
\text { D2 ANCILLARY WORK } \\
\text { D21 Demolition } \\
\text { D22 Alterations } \\
\end{array}$ & $\begin{array}{ll}1.0 & \text { SUBSTRUCTURE } \\
2.0 & \text { SUPERSTRUCTURE } \\
2.1 & \text { Frame } \\
2.2 & \text { Upper floors } \\
2.3 & \text { Roof } \\
2.4 & \text { Stairs } \\
2.5 & \text { External walls } \\
2.6 & \text { Windows and exterior doors } \\
2.7 & \text { Interior walls \& interior partitions } \\
2.8 & \text { Interior doors } \\
3.0 & \text { INTERNAL FINISHES } \\
3.1 & \text { Wall finishes } \\
3.2 & \text { Floor finishes } \\
3.3 & \text { Ceiling finishes } \\
4.0 & \text { FITTINGS AND FURNITURE } \\
4.1 & \text { Fittings and furnishings } \\
5.0 & \text { SERVICES } \\
5.1 & \text { Sanitary appliances } \\
5.2 & \text { Services equipment } \\
5.3 & \text { Disposal installations } \\
5.4 & \text { Water installations } \\
5.5 & \text { Heat source } \\
5.6 & \text { Space heating \& air treatment } \\
5.7 & \text { Ventilation systems } \\
5.8 & \text { Electrical installation } \\
5.9 & \text { Gas installation } \\
5.10 & \text { Life \& conveyor installation } \\
5.11 & \text { Protective installations } \\
5.12 & \text { Communication installations } \\
5.13 & \text { Special installations } \\
5.14 & \text { Builders work in connection with } \\
& \text { services } \\
5.15 & \text { Builders profit \& attendance on } \\
& \text { services } \\
6.0 & \text { EXTERNAL WORKS } \\
6.1 & \text { Site works } \\
6.2 & \text { Drainage } \\
6.3 & \text { External services } \\
6.4 & \text { Minor building work }\end{array}$ & $\begin{array}{l}\text { (1) SUBSTRUCTURE } \\
\text { SUPERSTRUCTURE } \\
\text { (2) Frame } \\
\text { (3) External walls } \\
\text { (4) Internal walls } \\
\text { (5) Floors } \\
\text { (6) Roofs } \\
\text { (7) Stairs } \\
\text { (8) Windows \& external doors } \\
\text { (9) Internal doors } \\
\text { FINISHES } \\
\text { (10) Internal wall finishes } \\
\text { (11) External wall finishes } \\
\text { (12) Floor finishes } \\
\text { (13) Ceiling finishes } \\
\text { (14) EQUIPMENT AND } \\
\text { FURNISHINGS SERVICES } \\
\text { (15) Plumbing } \\
\text { (16) Heating } \\
\text { (17) Ventilating \& air- } \\
\text { conditioning } \\
\text { (18) Internal drainage } \\
\text { (19) Electrics } \\
\text { (20) Communication } \\
\text { (21) Lifts, escalators, etc. } \\
\text { (22) Protective installations } \\
\text { (23) Miscellaneous services } \\
\text { inst. } \\
\text { EXTERNAL SITE WORKS } \\
\text { (24) Site preparation } \\
\text { (25) Site enclosure } \\
\text { (26) Site fittings } \\
\text { (27) Site services } \\
\text { (28) Site Buildings } \\
\text { (29) Hard and soft landscaping } \\
\text { (30) PRELIMINARIES }\end{array}$ \\
\hline
\end{tabular}

Source:Bowen, B. and Charette, R.P., "Elemental Cost Classification Standard for Building Design,"1991 American Association of Cost Engineers (AACE) Transactions, Seattle, Washington, 1991,

p. H2-1 to H2-5. 
cost, will help owners, project managers, designers, builders, facility managers, and users build and manage their buildings for lower life-cycle costs.

\subsection{The Building Life Cycle}

UNIFORMAT II has applications throughout the life cycle of a building. Figure 1.1 shows the five phases of the building life cycle that we use in this report. ${ }^{13}$ They are planning, programming, design, construction, and operations. UNIFORMAT II's elemental classification of building elements is recommended as the common thread for data description, monitoring, and evaluation throughout the five phases. This report shows in chapters 3 and 4 why UNIFORMAT II is useful over these phases, with particular emphasis on its applications for developing specifications and estimates at the programming and design stages.

Phase 1-Planning: The period during which a need/problem is identified and alternatives are developed and analyzed for satisfying the need. An example of planning is to identify and analyze several alternatives, such as leasing, building, and renovating, in response to the client's goals of accomplishing specific functions. Site requirements are defined and analyzed for each option. Preliminary schedules and cost estimates are made. If a decision to build is made, necessary authorizations and appropriations are obtained to proceed with the programming phase.

Phase 2 - Programming: The period during which project requirements in terms of scope, quality, cost, and time are defined in a program. The program defines user needs and sets objectives and guidelines for design professionals. In addition, owners, users, designers, and project managers use the program to evaluate the suitability of proposed design solutions. Commitments are obtained from all stakeholders, including policy makers and investors, based on the program. Design consultants must commit to meeting the program requirements, including those related to the budget and schedule, before being awarded a mandate and given authorization to proceed with the design.

We consider the program as having four principal sections: ${ }^{14}$ (1) a functional program; (2) a technical program; (3) a master schedule; and (4) a program cost estimate. The functional program documents and analyzes spatial relations; the number of occupants and their functional responsibility; space requirements expressed in both net and gross areas; and constraints. Site functional requirements are also documented and analyzed.

\footnotetext{
13 The description of phases throughout this report is generally consistent with the phases described in The American Institute of Architects, The Architect's Handbook of Professional Practice $-7^{\text {th }}$ Edition (Washington, D.C.: American Institute of Architects, 1992).

${ }^{14}$ The composition of Phases 2 and 3 is shown in figure 1.1. We treat the programming phase and the following design phase in greater detail than the other phases because the focus of our UNIFORMAT II applications in chapters 3 and 4 is on these two phases.
} 
Figure 1.1 Five Phases of the Building Life Cycle

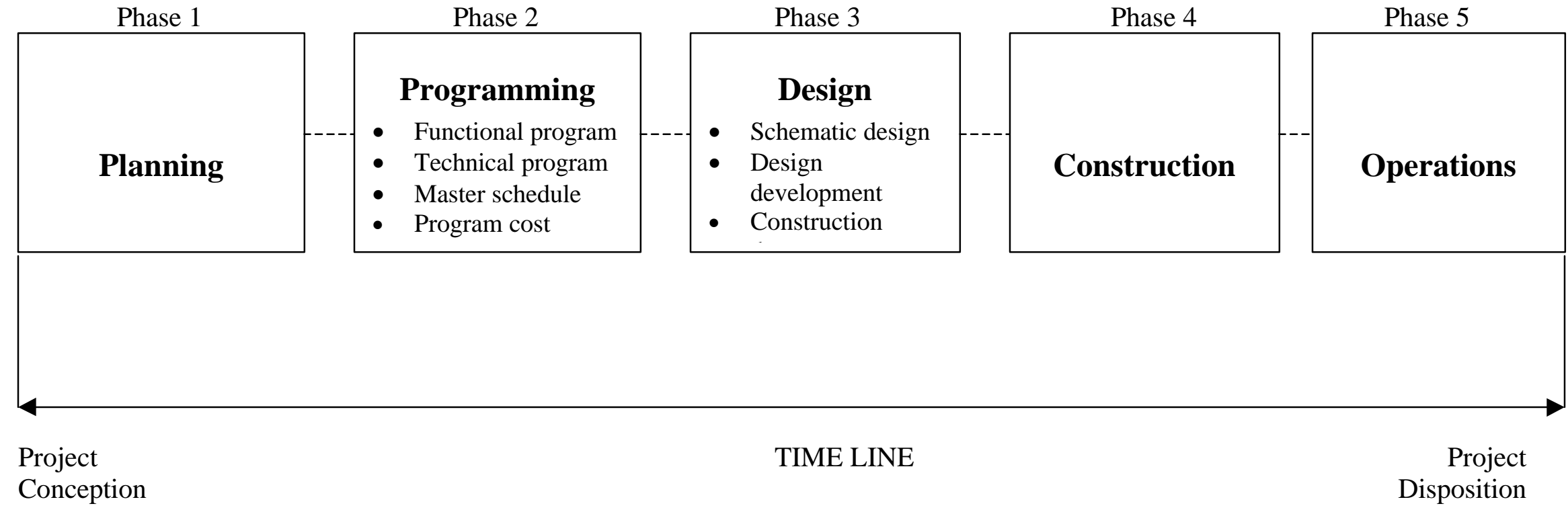


The technical program provides designers the performance specifications and technical requirements for the building elements and individual spaces. Performance specifications describe requirements in a manner that (1) indicates required results and (2) provides the criteria for verifying compliance with the specifications without stating how to achieve the results. Technical requirements are specific client directives and other technical information given to designers with respect to building systems, products, materials, design criteria, standards, practices, codes, and constraints. Organizations that construct facilities on a continuing basis, such as government agencies, the military, universities, large corporations, restaurant franchises, and chain stores generally incorporate technical requirements in their "Design Standards" documentation.

The master schedule for design and construction presents a plan of the major project tasks/milestones and completion dates. Project delivery options are analyzed in preparing the program schedule to determine the most cost-effective alternatives that meet the client's objectives.

The program cost estimate is based on the functional and technical program requirements. It provides a distribution of costs by building elements within the allocated budget. These costs reflect the performance and quality levels (See Table 4.1) anticipated by the client. This estimate is also a cost plan for comparing subsequent estimates and for monitoring and controlling costs as design progresses.

Phase 3 - Design: The period during which stated needs in the program are translated to plans and specifications. Detailed solutions to program requirements, updated cost estimates, and revised schedules are submitted for client approval as design progresses. Funds are appropriated, bids requested, and contracts awarded. The facilities design is typically prepared in a series of three, sequential, design subphases (Phase 3 block in figure 1.1). In each, the architect brings the design to an interim level of development, updates estimates, has the owner review and approve the work, and moves the project forward to the next level. The three sub-phases are schematic design, design development, and construction documents.

Schematic design establishes the general scope, conceptual design, and the scale relationships among the parts of the project. The primary goal is to clearly define a feasible concept within the allocated budget in a form that clients understand and approve before proceeding to design development.

In design development, all aspects of the design for each discipline are developed and coordinated. Drawings and specifications include floor plans, sections, exterior elevations, and for some parts of the building, interior elevations, reflected ceiling plans, wall sections, and key details. Basic mechanical, electrical, plumbing, and fire protection systems are also defined. Design development ends with approval by the owner of the plans, projected cost, and schedule. 
In the construction documents sub-phase, the design team works on the final material and system selections, details, and dimensions. Final plans and construction specifications are provided to bidders, and contracts are awarded.

Phase 4-Construction: The period during which plans and specifications are implemented into a finished structure which conforms to the specification requirements, construction schedule, and budget. Following commissioning, the building is ready for occupancy by the user.

Phase 5-Operations: The longest phase of a building's life cycle, during which it is operated to fulfill the owner's objectives. It is initiated at the date of beneficial occupancy. During this phase, a building may be retrofitted or recycled for a new function any number if times. Its life is terminated when the building is decommissioned and removed from the site.

\subsection{Organization}

Chapter 2 introduces the ASTM E1557-97 UNIFORMAT II classification that comprises three hierarchical levels for both building elements and related sitework elements. The chapter also presents the criteria used to determine which categories of elements were included and in what part of the hierarchy to include them. This classification differs from the 1992 version of UNIFORMAT II in NIST SP 841 in two respects: it has (1) an alphanumeric organizational system for all elements in the hierarchy and (2) revisions brought about by five years of the ASTM consensus process.

Chapter 3 describes how to apply UNIFORMAT II in writing performance specifications, technical requirements, and preliminary project descriptions. The chapter also lists and explains many of the benefits from using UNIFORMAT II in these applications.

Chapter 4 distinguishes elemental estimating from product-based estimating and explains the advantages of using elemental estimates in the design of buildings. Examples show the three ways to calculate element costs--using element unit rates and quantities, assembly costs and quantities, or component costs and quantities. Cost analysis parameters are defined and benefits from applying them are described. The chapter presents a two-page summary of an elemental estimate for an eight-story office building and explains how such a summary format aids communication among project stakeholders. A list of sources of elemental cost, engineering, and design data completes the chapter.

Chapter 5 presents a proposed list of Level-4 sub-elements for UNIFORMAT II. The advantages of having Level-4 sub-elements are described in detail.

Chapter 6 concludes the report with a summary and suggestions for further work. 
Appendix A provides professional profiles of the authors. Appendix B lists the building elements that are included and excluded in UNIFORMAT II level 3 categories.

Appendix $\mathrm{C}$ lists the titles of the 16 Divisions in CSI's MasterFormat 95 ${ }^{\mathrm{TM}}$. Appendix D lists abbreviations and symbols. Appendix E lists references. 


\section{UNIFORMAT II}

\subsection{Standard Classification of Elements}

The 1997 ASTM UNIFORMAT II standard classification of elements is shown in charts 2.1 and 2.2. ${ }^{15}$ Chart 2.1 presents UNIFORMAT II for Building Elements Levels 1 to 3 - Major Group Elements for Level 1, Group Elements for Level 2, and Individual Elements for Level 3. Chart 2.2 presents UNIFORMAT II for Building-Related Sitework Levels 1 to 3 .

Given that there are 57 Level-3 building elements, and 22 Level-3 sitework elements, it is sometimes difficult to find the appropriate element designator for an item in chart 2.1 or 2.2. For that reason, a list of what is normally included and excluded in each Level-3 element is provided in Appendix B. The listings of inclusions and exclusions are not intended to be exhaustive. Rather, they provide a general outline of what to expect in each element and help users find items quickly. For example, an elemental format might show exterior load bearing walls under B2010 Exterior Walls or B1010 Floor Construction. UNIFORMAT II puts them under B2010 Exterior Walls based on technical judgment and current practice. In Appendix B, under the exclusion list of B1010 Floor Construction, a cross-reference to B2010 Exterior Walls directs the person to the appropriate element.

The list of inclusions and exclusions is important in applying the 3-level UNIFORMAT II. Adopting a formal Level-4 sub-element classification, however, as suggested in Chapter 5, eliminates the uncertainty as to where to locate an item. Thus the UNIFORMAT II list of inclusions and exclusions would no longer be required.

\subsection{Criteria for Classification}

The framework for the UNIFORMAT II classification (including Level 4), the selection of items to include, and the decisions in which parts of the classification to include the items are based on the following criteria:

- framework is hierarchical to allow aggregation and summarization at different levels

- framework is suitable for a range of applications, including cost control and schematic phase preliminary project descriptions

- framework accommodates unlisted items based on the judgment of building professionals

- selected items have a significant influence on project cost

- selected items have high frequency of occurrence

- selected items are distinctive

- professional judgment used to place elements where building professionals in current practice would normally look for such items in a classification

\footnotetext{
${ }^{15}$ The classification of elements appears in figures 2 and 3 of the ASTM Standard E1557-97.
} 
Chart 2.1 ASTM UNIFORMAT II Classification for Building Elements (E1557-97)

\begin{tabular}{|c|c|c|}
\hline $\begin{array}{c}\text { Level } 1 \\
\text { Major Group Elements }\end{array}$ & $\begin{array}{c}\text { Level } 2 \\
\text { Group Elements }\end{array}$ & $\begin{array}{c}\text { Level } 3 \\
\text { Individual Elements }\end{array}$ \\
\hline \multirow[t]{2}{*}{ A $\quad$ SUBSTRUCTURE } & A10 Foundations & $\begin{array}{ll}\text { A1010 } & \text { Standard Foundations } \\
\text { A1020 } & \text { Special Foundations } \\
\text { A1030 } & \text { Slab on Grade }\end{array}$ \\
\hline & A20 Basement Construction & $\begin{array}{ll}\text { A2010 } & \text { Basement Excavation } \\
\text { A2020 } & \text { Basement Walls }\end{array}$ \\
\hline \multirow[t]{3}{*}{ B SHELL } & B10 Super Structure & $\begin{array}{ll}\text { B1010 } & \text { Floor Construction } \\
\text { B1020 } & \text { Roof Construction }\end{array}$ \\
\hline & B20 Exterior Enclosure & $\begin{array}{ll}\text { B2010 } & \text { Exterior Walls } \\
\text { B2020 } & \text { Exterior Windows } \\
\text { B2030 } & \text { Exterior Doors } \\
\end{array}$ \\
\hline & B30 Roofing & $\begin{array}{ll}\text { B3010 } & \text { Roof Coverings } \\
\text { B3020 } & \text { Roof Openings }\end{array}$ \\
\hline \multirow[t]{3}{*}{$\begin{array}{ll}\text { C } & \text { INTERIORS }\end{array}$} & $\begin{array}{ll}\text { C10 Interior Construction } \\
\text {. }\end{array}$ & $\begin{array}{ll}\text { C1010 } & \text { Partitions } \\
\text { C1020 } & \text { Interior Doors } \\
\text { C1030 } & \text { Fittings }\end{array}$ \\
\hline & C20 Stairs & $\begin{array}{ll}\text { C2010 } & \text { Stair Construction } \\
\text { C2020 } & \text { Stair Finishes }\end{array}$ \\
\hline & C30 Interior Finishes & $\begin{array}{ll}\text { C3010 } & \text { Wall Finishes } \\
\text { C3020 } & \text { Floor Finishes } \\
\text { C3030 } & \text { Ceiling Finishes }\end{array}$ \\
\hline \multirow[t]{5}{*}{ D $\quad$ SERVICES } & D10 $\quad$ Conveying & $\begin{array}{ll}\text { D1010 } & \text { Elevators \& Lifts } \\
\text { D1020 } & \text { Escalators \& Moving Walks } \\
\text { D1090 } & \text { Other Conveying Systems } \\
\end{array}$ \\
\hline & D20 $\quad$ Plumbing & $\begin{array}{ll}\text { D2010 } & \text { Plumbing Fixtures } \\
\text { D2020 } & \text { Domestic Water Distribution } \\
\text { D2030 } & \text { Sanitary Waste } \\
\text { D2040 } & \text { Rain Water Drainage } \\
\text { D2090 } & \text { Other Plumbing Systems } \\
\end{array}$ \\
\hline & D30 HVAC & $\begin{array}{ll}\text { D3010 } & \text { Energy Supply } \\
\text { D3020 } & \text { Heat Generating Systems } \\
\text { D3030 } & \text { Cooling Generating Systems } \\
\text { D3040 } & \text { Distribution Systems } \\
\text { D3050 } & \text { Terminal \& Package Units } \\
\text { D3060 } & \text { Controls \& Instrumentation } \\
\text { D3070 } & \text { Systems Testing \& Balancing } \\
\text { D3090 } & \text { Other HVAC Systems \& } \\
& \text { Equipment } \\
\end{array}$ \\
\hline & D40 $\quad$ Fire Protection & $\begin{array}{ll}\text { D4010 } & \text { Sprinklers } \\
\text { D4020 } & \text { Standpipes } \\
\text { D4030 } & \text { Fire Protection Specialties } \\
\text { D4090 } & \text { Other Fire Protection Systems }\end{array}$ \\
\hline & $\begin{array}{ll}\text { D50 } & \text { Electrical }\end{array}$ & $\begin{array}{ll}\text { D5010 } & \text { Electrical Service \& Distribution } \\
\text { D5020 } & \text { Lighting and Branch Wiring } \\
\text { D5030 } & \text { Communications \& Security } \\
\text { D5090 } & \text { Other Electrical Systems } \\
\end{array}$ \\
\hline \multirow[t]{2}{*}{$\begin{array}{l}\text { E } \text { EQUIPMENT \& } \\
\text { FURNISHINGS }\end{array}$} & E10 Equipment & $\begin{array}{ll}\text { E1010 } & \text { Commercial Equipment } \\
\text { E1020 } & \text { Institutional Equipment } \\
\text { E1030 } & \text { Vehicular Equipment } \\
\text { E1090 } & \text { Other Equipment } \\
\end{array}$ \\
\hline & E20 Furnishings & $\begin{array}{ll}\text { E2010 } & \text { Fixed Furnishings } \\
\text { E2020 } & \text { Movable Furnishings }\end{array}$ \\
\hline \multirow[t]{2}{*}{ 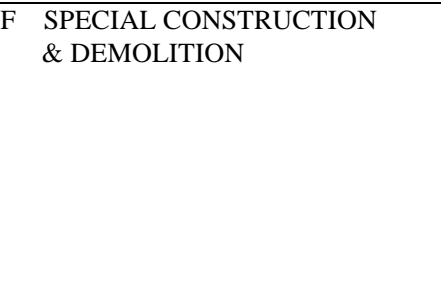 } & $\begin{array}{ll}\text { F10 } & \text { Special Construction }\end{array}$ & $\begin{array}{ll}\text { F1010 } & \text { Special Structures } \\
\text { F1020 } & \text { Integrated Construction } \\
\text { F1030 } & \text { Special Construction Systems } \\
\text { F1040 } & \text { Special Facilities } \\
\text { F1050 } & \begin{array}{l}\text { Special Controls and } \\
\text { Instrumentation }\end{array} \\
\end{array}$ \\
\hline & $\begin{array}{ll}\text { F20 } & \text { Selective Building } \\
& \text { Demolition }\end{array}$ & $\begin{array}{ll}\text { F2010 } & \text { Building Elements Demolition } \\
\text { F2020 } & \begin{array}{l}\text { Hazardous Components } \\
\text { Abatement }\end{array} \\
\end{array}$ \\
\hline
\end{tabular}




\section{Chart 2.2 ASTM UNIFORMAT II Classification for Building-Related Sitework (E1557-97)}

\begin{tabular}{|c|c|c|}
\hline $\begin{array}{c}\text { Level 1 } \\
\text { Major Group Elements }\end{array}$ & $\begin{array}{c}\text { Level } 2 \\
\text { Group Elements }\end{array}$ & $\begin{array}{c}\text { Level } 3 \\
\text { Individual Elements }\end{array}$ \\
\hline \multirow[t]{5}{*}{ G $\quad$ BUILDING SITEWORK } & G10 Site Preparation & $\begin{array}{ll}\text { G1010 } & \text { Site Clearing } \\
\text { G1020 } & \text { Site Demolition and Relocations } \\
\text { G1030 } & \text { Site Earthwork } \\
\text { G1040 } & \text { Hazardous Waste Remediation } \\
\end{array}$ \\
\hline & G20 Site Improvements & $\begin{array}{ll}\text { G2010 } & \text { Roadways } \\
\text { G2020 } & \text { Parking Lots } \\
\text { G2030 } & \text { Pedestrian Paving } \\
\text { G2040 } & \text { Site Development } \\
\text { G2050 } & \text { Landscaping } \\
\end{array}$ \\
\hline & G30 Site Mechanical Utilities & $\begin{array}{ll}\text { G3010 } & \text { Water Supply } \\
\text { G3020 } & \text { Sanitary Sewer } \\
\text { G3030 } & \text { Storm Sewer } \\
\text { G3040 } & \text { Heating Distribution } \\
\text { G3050 } & \text { Cooling Distribution } \\
\text { G3060 } & \text { Fuel Distribution } \\
\text { G3090 } & \text { Other Site Mechanical Utilities }\end{array}$ \\
\hline & G40 Site Electrical Utilities & $\begin{array}{ll}\text { G4010 } & \text { Electrical Distribution } \\
\text { G4020 } & \text { Site Lighting } \\
\text { G4030 } & \text { Site Communications \& Security } \\
\text { G4090 } & \text { Other Site Electrical Utilities } \\
\end{array}$ \\
\hline & G90 Other Site Construction & $\begin{array}{ll}\text { G9010 } & \text { Service and Pedestrian Tunnels } \\
\text { G9090 } & \text { Other Site Systems \& Equipment }\end{array}$ \\
\hline
\end{tabular}

The classification was designed to meet the following additional requirements:

- applies to any building type, although it is designed for commercial buildings

- allows for specific details required for describing specialized buildings

- separates the classification of building elements from the classification of buildingrelated sitework

- relates to other elemental classifications such as the original UNIFORMAT and those of the Canadian Institute of Quantity Surveyors (CIQS) and the Royal Institute of Chartered Surveyors (RICS-UK)

UNIFORMAT II is not intended to classify elements of major civil works. Buildings, however, are usually accompanied by roads, utilities, parking areas, and other nonbuilding features. The UNIFORMAT II classification of building-related sitework is provided for exclusive use in support of construction of buildings so users do not have to resort to multiple elemental classifications for what is primarily a buildings project.

\subsection{The Relationship of UNIFORMAT II to Other Elemental Classifications}

Many of the elements in UNIFORMAT II are found in other North American elemental formats such as the GSA/AIA UNIFORMAT classification, the TRACES ${ }^{16}$ Work

\footnotetext{
${ }^{16}$ TRACES stands for Tri-Services Automated Cost Engineering Systems. Information on TRACES may be found in The Delta Research Corporation Report TRACES Generic Work Breakdown Structure (Washington, DC: Tri-Services WBS Subcommittee, 1992) and in The National Institute of Building
} 
Breakdown Structure (WBS), and the CIQS and RAIC classifications. UNIFORMAT II also has similarities to international classifications such as the RICS and the CEEC.

\subsection{Additional Levels of Definition}

The original UNIFORMAT classification had 7 levels of definition that extended to products and materials. The current UNIFORMAT II ASTM standard has 3 levels of definition, with Level 3 being the most detailed. Chapter 5 provides a Level-4 subelement classification as an additional formal level of elemental breakdown to be considered for inclusion in the UNIFORMAT II ASTM standard.

Sciences (NIBS) Construction Criteria Base (CCB) CD-ROM in the "Costs" section (Washington, DC: National Institute of Building Sciences). 


\section{Applying UNIFORMAT II For Specifications}

\subsection{Overview}

While the original UNIFORMAT classification was developed specifically for design phase estimates, UNIFORMAT II is applicable in all phases of a building's life cycle. The classification is currently applied for:

- Planning Estimates

- Program Performance Specifications

- Program Technical Requirements

- Program Estimates

- Preliminary Project Descriptions

- Preliminary Construction Schedules and Cash Flow Projections ${ }^{17}$

- Design Phase Estimates

- CAD Layering

- Cost Risk Analysis ${ }^{18}$

- Life-Cycle Cost Analysis Reporting

- Function-Cost Models and Brainstorming Checklists in Value Engineering ${ }^{19}$

- Checklists for Technical Design Reviews

- Design-Build Facilities Procurement

- Construction Progress Reporting for Interim Payments

- Construction Claims Analysis

- Building Condition Evaluation

- Scope of Work Definition for Building Renovations and Retrofits

- Long-Term Capital Replacement Budgeting

- Classifying and Filing Product Literature

- Organizing Design, Engineering, and Cost Information for Manuals and Databases

- Organizing Maintenance and Life-Cycle Cost Data

In this Chapter and Chapter 4, we focus on selected applications of UNIFORMAT II in the programming and design phases of the building life cycle. Chapter 3 treats specifications, and Chapter 4 treats estimates. We select these applications for illustration for two reasons: each building construction project requires specifications and estimates, and significant benefits are expected from the use of UNIFORMAT II.

\footnotetext{
${ }^{17}$ Ahuja, N. Hira, and Campbell, Walter J., Estimating from Concept to Completion (Englewood Cliffs, NJ: Prentice-Hall, Inc., 1988), and The Royal Architectural Institute of Canada, "Cost Planning and Cost Control Techniques," Volume 3, Canadian Handbook of Practice for Architects, $1^{\text {st }}$ Edition (Ottawa, Ontario, Canada: The Royal Architectural Institute of Canada, 1978), pp. 43-49.

${ }^{18}$ American Society for Testing and Materials, ASTM E1496: "Standard Practice for Measuring Cost Risk of Buildings and Building Systems" (West Conshohocken, PA: American Society for Testing and Materials, 1998).

${ }^{19}$ Dell'Isola, Michael, "Value Engineering Applications Using UNIFORMAT II," Proceedings of the Society of American Value Engineers (SAVE) (Atlanta, GA: 1998), pp.72-82.
} 
The term "specification" in this report describes any written document developed during programming and design that describes the performance or technical aspects of a building project, as shown in Chart 3.1.

Program specifications are comprised of "Performance Specification" and "Technical Requirements."

Design specifications are comprised of "Preliminary Project Descriptions" (PPD) at the Schematic Design stage; "Outline Specifications" at the Design Development stage; and "Construction Specifications" at the Construction Documents stage.

This chapter recommends how to structure performance specifications, technical requirements, and preliminary project descriptions according to UNIFORMAT II. Outline Specifications and Construction Specifications are not addressed since these are normally structured according to MasterFormat $95^{\mathrm{TM}}$ Divisions 1-16, as shown in Chart 3.1 .

The impetus for applying the UNIFORMAT II classification to specifications came in 1989 when CSI recommended that projects at the schematic stage be described in a simple narrative form by building elements in lieu of products. The CSI recommendations are incorporated in the FF/180 Practice — "Preliminary Project Descriptions and Outline Specifications." ${ }^{20}$ Prior to that time, the UNIFORMAT classification had been utilized primarily for estimating and cost control.

\section{Chart 3.1 Program and Design Specifications}

\begin{tabular}{|c|c|}
\hline $\begin{array}{c}\text { PROGRAM } \\
\text { SPECIFICATIONS } \\
\end{array}$ & $\begin{array}{c}\text { DESIGN } \\
\text { SPECIFICATIONS } \\
\end{array}$ \\
\hline $\begin{array}{c}\text { TECHNICAL PROGRAM } \\
\text { Performance Specifications } \\
\text { (UNIFORMAT II) }\end{array}$ & $\begin{array}{c}\text { SCHEMATIC DESIGN } \\
-\quad \text { Preliminary Project Description (PPD) } \\
\text { (UNIFORMAT II) }\end{array}$ \\
\hline $\begin{array}{c}\text { - Technical Requirements } \\
\text { (UNIFORMAT II) }\end{array}$ & $\begin{array}{l}\text { DESIGN DEVELOPMENT } \\
\text { - Outline Specifications } \\
\text { (MasterFormat 95'T) }\end{array}$ \\
\hline & $\begin{array}{c}\text { CONSTRUCTION DOCUMENTS } \\
\text { - Construction Specifications } \\
\text { (MasterFormat 95 } \\
\text { (MM) }\end{array}$ \\
\hline
\end{tabular}

${ }^{20}$ Construction Specifications Institute, Practice FF/180, "Preliminary Project Descriptions and Outline Specifications," Manual of Practice (Alexandria, VA: The Construction Specifications Institute, 1996). 


\subsection{Performance Specifications}

Performance specifications set forth results to be achieved but not the means for achieving them. Performance specifications thus differ from prescriptive or descriptive specifications that describe specific products or systems. With performance specifications there is more freedom of choice for the materials, fabrication technique, and method of installation. Performance specifications encourage the use of creativity and innovation in fulfilling requirements in a manner that is most economical to the owner. By using UNIFORMAT II to structure the performance specification, an object reference base is created for evaluating and monitoring the performance of building elements throughout the project's life cycle.

Examples of performance and descriptive specifications for Element B3010, Roof Coverings, is presented in Chart 3.2. With a performance specification, a product that meets the stated performance is considered acceptable, no matter what technical solution is advanced. With a prescriptive specification, the choice is restricted to solutions with PVC membranes and polysocyanurate roof insulation, thus precluding any search for alternatives that might be less costly, perform better, or both.

\section{Chart 3.2 Performance and Descriptive Specifications For Element B3010, Roof Coverings}

$\begin{array}{cc}\text { PERFORMANCE } & \text { DESCRIPTIVE/PRESCRIPTIVE } \\ \text { SPECIFICATIONS } & \text { SPECIFICATIONS }\end{array}$

- $\quad$ "Roof: UL Class A Roof Assembly with a flame spread of 25 or less, consisting of insulation having a thermal resistance rating of $\mathrm{R}-14$, and a membrane attached in a manner to obtain FM I-90 wind uplift rating"
- $\quad$ "Roof: 0.19 inch thick PVC mechanically attached membrane over 2 inch thick polylsocyanurate roof insulation"

Source: Adapted from CSI FF/180, p. 2.

Design-build projects are usually bid on the basis of performance specifications. PerSpective $^{\mathrm{TM}}$ is a design-build performance specification template based on UNIFORMAT that was developed as a joint project of the Design-Build Institute of America (DBIA) and the Construction Specification Institute (CSI). ${ }^{21}$ In the United Kingdom, the Chartered Institute of Buildings and the Royal Institution of Chartered

${ }^{21}$ Construction Specification Institute and Design-Build Institute of America, PerSpective ${ }^{\mathrm{TM}}$, The Performance System for Project Teams (Alexandria, VA: Construction Specification Institute; Washington, DC: Design-Build Institute of America, April 1999). Web site - www.perspective.net.com. 
Surveyors also recommend elemental performance specifications for design-build projects. $^{22}$

\subsection{Technical Requirements}

Technical requirements provide consultants with written design guidelines, directives, and other pertinent information prior to design being initiated. This information pertains to building systems, products, materials, design criteria, standards, codes, and constraints. Technical requirements reflect decisions of the client as to the technologies to be used. An example is the requirement for low-pressure boilers to eliminate the need for operators that are required with high-pressure boilers. Such information transmitted in writing rather than verbally minimizes misunderstanding and design delays, and results in increased design efficiency.

Structuring the program's technical requirements according to UNIFORMAT II simplifies access to the information by all project team members. Information can be provided at any of the three (or four) levels of the classification that seems appropriate. The hierarchical structure of UNIFORMAT II greatly facilitates the transmittal of technical data. Chart 3.3 shows examples of UNIFORMAT II used in presenting program technical requirements for a variety of elements.

\subsection{Preliminary Project Description (PPD)}

During the Schematic Design stage (Phase 3 in Figure 1.1), consultants prepare concept drawings and a description (specification) of building systems proposed by each discipline. These documents must be approved by the client and other stakeholders before proceeding with the Design Development stage.

CSI's FF/180 Practice ${ }^{23}$ recommends the preparation of a PPD based on UNIFORMAT elements at the schematic design stage to communicate in a clear, concise manner the scope and relationship of major building systems and to expedite approval. Since the selection of most products has not been made or finalized at this stage, a product classification such as MasterFormat 95 ${ }^{\mathrm{TM}}$ Divisions 1-16 is not as effective as an elemental classification such as UNIFORMAT II in communicating design information to the client, consultants, and other stakeholders. An example of a Preliminary Project Description from the CSI FF/180 Practice is presented in Chart 3.4.

CSI's FF/180 Practice also recommends an "Outline Specification" for the Design Development stage based on the MasterFormat ${ }^{\mathrm{TM}}$ Division 1-16 product classification (Appendix C). This specification is the basis for the construction specifications of the Construction Documents stage.

\footnotetext{
${ }^{22}$ Martin, J. and Rumble, P., An Elemental Approach to Design and Build Contracts (Berkshire, England: The Chartered Institute of Buildings, Construction Papers No. 79, 1997), and Royal Institution of Chartered Surveyors (RICS)—Building Cost Information Service Ltd. (BCIS), Elements for Design and Build (London, England: Royal Institution of Chartered Surveyors, 1996).

${ }^{23}$ Construction Specification Institute, Practice FF/180, p.1.
} 


\section{Chart 3.3 Examples of UNIFORMAT II Used in Presenting Technical Program Requirements}

ELEMENT

TECHNICAL REQUIREMENTS

\begin{tabular}{|c|c|}
\hline A1010_-Standard Foundations & $\begin{array}{l}\text { Provisions for supporting future additional } \\
\text { floors }\end{array}$ \\
\hline B1010_Floor Construction & $\begin{array}{l}\text { For major retrofit projects, existing seismic } \\
\text { studies and estimates for upgrading } \\
\text { existing structures }\end{array}$ \\
\hline B2010_Exterior Walls & $\begin{array}{l}\text { Matching wall cladding to that of adjacent } \\
\text { buildings; mock-up requirements. }\end{array}$ \\
\hline D2010_Plumbing Fixtures & Wall-hung fixtures (client standard) \\
\hline D1010_Elevators and Lifts & $\begin{array}{l}\text { Optional annual maintenance contracts } \\
\text { with bids to supply and install }\end{array}$ \\
\hline D3020_-Heat Generating Systems & $\begin{array}{l}\text { Maximum allowable steam boiler pressure } \\
\text { to eliminate the need for operators required } \\
\text { by code. }\end{array}$ \\
\hline $\begin{array}{l}\text { D5010_Electrical Service and } \\
\text { Distribution }\end{array}$ & $\begin{array}{l}\text { Ownership of high tension electrical } \\
\text { transformer sub-station (utility or client) }\end{array}$ \\
\hline D5020_-Lighting and Branch Wiring & $\begin{array}{l}\text { Motion detectors and daylight sensors to } \\
\text { control lighting for energy conservation }\end{array}$ \\
\hline $\begin{array}{l}\text { F2020-Hazardous Components } \\
\text { Abatement }\end{array}$ & $\begin{array}{l}\text { Availability of original plans and } \\
\text { specifications; existing studies and } \\
\text { estimates on asbestos abatement }\end{array}$ \\
\hline
\end{tabular}




\section{Chart 3.4 Preliminary Project Description (PPD) $)^{24}$}

B SHELL

B10 SUPERSTRUCTURE

B1010 FLOOR CONSTRUCTION

A. Floor System: Two-hour fire-rated, composite steel beam, steel deck, and concrete slab system in 20-foot by 25 -foot bay dimensions capable of supporting 75 PSF live load.

\section{B1020 ROOF CONSTRUCTION}

A. Roof System: Two-hour fire-rated, composite steel beam, steel deck, and concrete slab system in 20-foot by 25-foot bay dimensions capable of supporting 30 PSF live load.

\section{B20 EXTERIOR CLOSURE}

\section{B2010 EXTERIOR WALLS}

A. Masonry Cavity Wall Construction:

1. Modular face brick installed in running bond with tooled concave joints.

2. Extruded polystyrene board installed between horizontal masonry reinforcing.

3. Bituminous dampproofing applied over concrete masonry units.

4. Load-bearing concrete masonry units with galvanized horizontal joint reinforcement.

5. Concrete masonry unit lintel units over openings; concrete masonry unit bond beams at top of wall.

B. Loose galvanized steel lintels over brick openings with 8-inch minimum bearing on each side of opening

C. Elastomeric masonry flashing at sills, lintels, and other cavity interruptions.

D. Open weep holes in brick masonry at flashing locations on 24-inch centers.

\section{B2020 EXTERIOR WINDOWS}

A. Windows: Commercial-grade, aluminum double-hung windows with clear anodized finish and clear insulating glass.

\section{B2030 EXTERIOR DOORS}

A. Doors and frames: Insulated, exterior flush steel doors set in steel frames.

B. Hardware: Ball bearing butts, closers, locksets, thresholds, and weatherstripping.

\footnotetext{
${ }^{24}$ Construction Specification Institute, Practice FF/180, p. 5.
} 
Some of the benefits from using UNIFORMAT II to structure PPDs at the Schematic Design stage are the following.

Requiring all disciplines to think the project through at the Schematic Design stage rather than at the later Design Development stage reduces cycle time and design costs. The UNIFORMAT II structure on which the PPD narrative is based makes the project more understandable to all disciplines and stakeholders - the client, project manager, designers, facility managers, and end users. The PPD organized according to the UNIFORMAT II framework encourages comments more quickly than usual, thereby facilitating and encouraging design changes early in the design process when they are least costly.

Using Levels 3 and 4 of UNIFORMAT II as checklists for all disciplines when defining the project reduces the probability of omissions in the PPD.

Defining baseline systems in the PPD facilitates preparing elemental cost estimates and allows the analyst to compare them early to established budgets, both for initial investment costs and operations and maintenance costs over the project life. This results in fewer allowances for unknowns, reduced contingencies, and more detailed and accurate estimates, thereby reducing the likelihood of future cost overruns and costly redesigns.

Using the UNIFORMAT II framework for constructing the PPD and initial elemental cost estimate encourages the project team to carry out life-cycle costing, energy analysis, and value engineering before design development begins. This helps designers make cost-effective choices early in the building life cycle, when the greatest savings are to be achieved.

Having an elemental PPD makes it easier to establish an audit trail as called for in ISO 9000 Quality Management Programs. ${ }^{25}$

Using UNIFORMAT II consistently in preparing PPDs, regardless of the project type, location, or design team, improves communication among all stakeholders. It encourages the coordination of building systems to start earlier among all disciplines. Possible benefits are project managers having more time to manage, a reduced cycle time for project commissioning, and owners seeing more projects completed within the budget.

\footnotetext{
25 International Organization for Standardization, ISO 9001, "Standard Model for Quality Assurance in Design, Development, Production, Installation, and Servicing," Element 4.9-Process Control (Geneva, Switzerland: International Organization for Standardization), p. 6.
} 


\section{UNIFORMAT II For Elemental Estimates and Design Cost Analysis}

Chapter 4 compares elemental and product estimates, describes the benefits from elemental design estimates, and illustrates with examples different ways to calculate elemental costs. An elemental estimate format incorporating cost analysis parameters is recommended to facilitate comparisons with targeted costs and those of similar projects in historical databases. An example of an elemental estimate is illustrated with an eightstory office building. Sources of elemental cost, engineering, and design data are provided.

\subsection{Overview of Design and Construction Cost Estimates}

Cost estimates for building construction projects in North America are generally based on either a product classification or an elemental classification.

Construction product estimates prepared by contractors (trade estimates) usually reference the CSI MasterFormat 95 ${ }^{\mathrm{TM}}$ Divisions 1-16 product classification (Appendix C) that was initially developed for specifications. MasterFormat $95^{\mathrm{TM}}$ is also used extensively for design estimates because designers use it for specifications and are familiar with it. However, with more emphasis being placed on controlling building construction costs during design, it is becoming evident that Divisions 1-16 estimates are not suitable for design cost analysis and monitoring of costs as design progresses, particularly during early design phases.

UNIFORMAT II elemental estimates, on the other hand, facilitate design cost analysis and monitoring of costs from the programming phase through the completion of construction documents. ${ }^{26}$ In addition, at the schematic design stage, elemental estimates are linked directly to the PPD as shown in Chart 4.1, since both are structured according to UNIFORMAT II. Organizing cost information at the schematic design stage with the same elemental designators used for the PPD is a relatively recent and innovative approach that yields several benefits for building project stakeholders.

First, at the schematic design stage, all project participants, technical and non-technical, can relate costs directly to the scope as described in the PPD. Second, the early release of project description and cost data encourages stakeholders to make design tradeoffs early on the basis of both performance and costs, thereby reducing cycle time and lowering project costs. Finally, elements with a high degree of uncertainty regarding costs or time to completion will be identified early so that action can be taken to minimize the associated risks.

\footnotetext{
${ }^{26}$ Note that UNIFORMAT II is not recommended for preparing product-based MasterFormat $95^{\mathrm{TM}}$ estimates.
} 


\section{Chart 4.1 UNIFORMAT II Links Elemental Preliminary Project Descriptions and Design Cost Estimates}

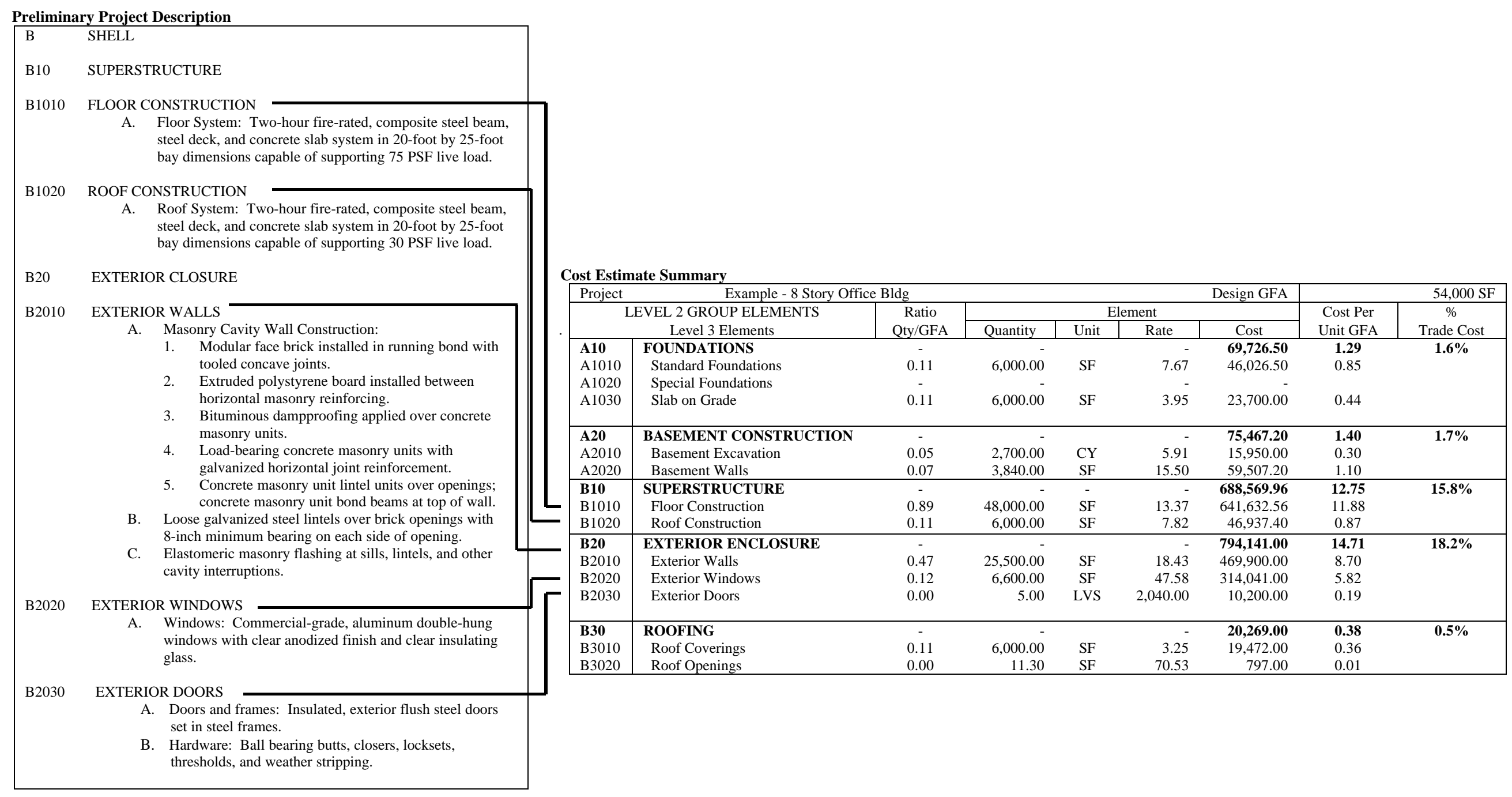




\subsection{Benefits of Elemental Design Estimates}

Some of the benefits from using UNIFORMAT II to structure program and design estimates are the following:

- Elemental designators are identical to those of the technical program and the preliminary project descriptions. The relationship between project scope and cost can therefore be understood more readily.

- "Composite" elemental costs are used for early design estimates, thereby eliminating the time-consuming and costly exercise of identifying, quantifying, and costing material and labor for each product. (See the example of computing a component versus elemental estimate in section 4.3, Elemental Costs.)

- Elemental rates communicate the quality level of elements as shown in Table 4.1. For example, for element B2010, Exterior Walls, a rate of $\$ 32.00 / \mathrm{SF}$ indicates standard corporate office building quality. A rate of $\$ 65.00 / \mathrm{SF}$, on the other hand, indicates that the quality level is that of a monumental type building. Elemental estimates can therefore be initially prepared based on the anticipated quality level of a building project without knowing the specific products that make up the elements. This approach is explained in "Project Budgeting for Buildings." 27

- Elemental program estimates provide a more realistic distribution of costs for assigning design-to-cost targets for each discipline than do arbitrary percentage allocations that do not necessarily reflect program requirements or anticipated quality levels.

- Elemental costs can be monitored, element by element, from the programming phase through the final design phase, making it easier to document the "audit trail" required in quality management programs.

- Most design changes, even major ones, can be quickly evaluated at any phase, because the total cost of each element is usually proportional to its quantity, thus simplifying calculations. There is no need to quantify and price individual components or products that make up the element-a tedious, costly, and lengthy exercise.

- Cost overruns are detected earlier because costs are monitored frequently, at each stage of design. This allows necessary corrective design changes to be made early, with little effect on the design schedule and minimum impacts on the cost of design.

- Consistent, standardized reporting of costs from project to project facilitates the rapid preparation and analysis of estimates.

- Elemental unit rates that are generated in cost estimates are suitable for recycling in data banks and can be drawn upon to prepare estimated costs of future projects.

\footnotetext{
${ }^{27}$ Parker, Donald E., and Dell'Isola, Alphonse J., Project Budgeting for Buildings (New York, New York: Van Nostrand Reinhold, 1991), pp.67-72.
} 
- Cost risk analyses that quantify the probability and magnitude of cost overruns are easier to prepare because cost analysts will always be working with a consistent cost reporting format from the programming stage to the completion of construction documents. Every cost estimate could be presented with a risk analysis that shows the probability distribution associated with that estimate. An example of a cost risk analysis based on a UNIFORMAT II estimate is included in ASTM Standard E1496. ${ }^{28}$

- Project Managers will save time because design estimates presented by UNIFORMAT II elements will preclude their having to unscramble the content of estimates whose formats vary extensively from project to project. ${ }^{29}$

Table 4.1 B2010 Exterior Walls-Quality Levels and Unit Costs

\begin{tabular}{llll}
\hline & Quality Level & Element Description & Element Cost/SF \\
\hline 1. & Monumental & Granite & $\$ 65.00$ \\
2. & Federal & Brick & $\$ 42.00$ \\
3. & Corporate & Curtain Wall & $\$ 32.00$ \\
4. & Commercial & Precast & $\$ 22.00$ \\
\hline
\end{tabular}

\subsection{Elemental Costs}

UNIFORMAT II elemental costs include material costs, labor costs, and sub-contractor overhead and profit. An element's cost is calculated by (a) multiplying the unit cost (also called unit rate) times the quantity of the element, (b) summing the costs of the assemblies that constitute the element, or (c) summing the material and labor costs of the system components that make up the element. At any stage of cost estimating, elemental estimates can be based on elemental rates and quantities or the summing of assembly and component costs, or both. Using one approach for some elements does not restrict the use of other approaches for other elements in that same estimate.

\footnotetext{
${ }^{28}$ ASTM E1496: "Standard Practice for Measuring Cost Risk of Buildings and Building Systems."

${ }^{29}$ Charette, Robert P., New Design Management Tools for Project Managers, The Association for Project Managers (APM) Journal, Volume 5, Issue 3, May 1998. Available on the APM website, www.construction.st/UNIFORMAT.htm.
} 


\subsubsection{Unit Rates and Quantities}

Chart 4.2 provides an elemental unit rate, measured in cost per square foot, for a brick face, composite, exterior wall. Rather than each time estimating separately the material, labor, and overhead costs, and adding that sum to the subcontractor's profit, go directly to the table and use the composite rate of $\$ 19.25$ to quickly estimate the cost of the total wall area required. Simply multiply the unit rate $(\$ 19.25 / \mathrm{SF})$ times the estimated number of units. If the estimated wall area were 1,000 SF, for example, then the estimated cost of the element would be $\$ 19,250$.

\section{Chart 4.2 Unit Rates for Brick Face Composite Wall, ${ }^{30}$ Element B2010}

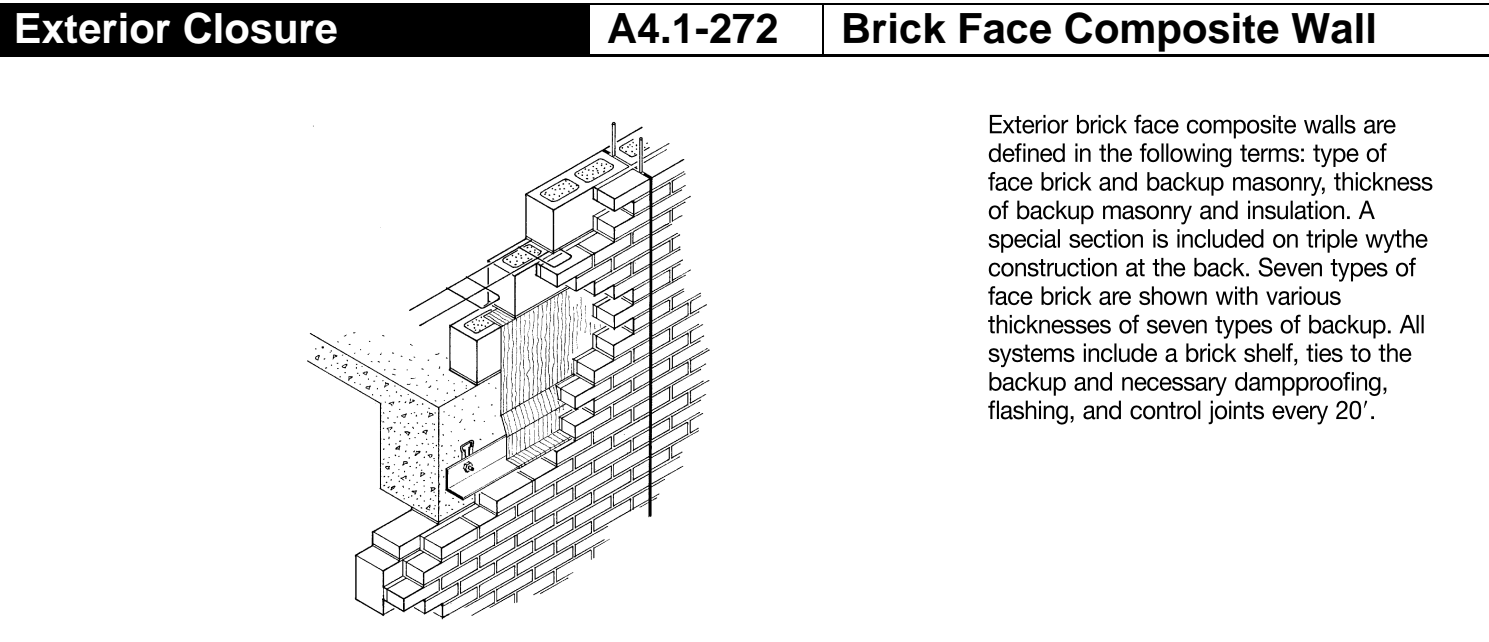

\begin{tabular}{|c|c|c|c|c|c|}
\hline \multirow[b]{2}{*}{ SYSTEM COMPONENTS } & \multirow[b]{2}{*}{ QUANTITY } & \multirow[b]{2}{*}{ UNIT } & \multicolumn{3}{|c|}{ \$ COST PER SF } \\
\hline & & & MAT. & INST. & TOTAL \\
\hline $\begin{array}{l}\text { SYSTEM 4.1-272-1120 } \\
\text { COMPOSITE WALL, STANDARD BRICK, 6" } \\
\text { C.M.U.BACKUP,PERLITE FILL } \\
\text { Face brick veneer, standard, running bond } \\
\text { Wash brick } \\
\text { Concrete block backup, 6" thick } \\
\text { Wall ties } \\
\text { Perlite insulation, poured } \\
\text { Flashing, aluminum } \\
\text { Shelf angle } \\
\text { Control joint } \\
\text { Backer rod and sealant } \\
\text { Collar joint }\end{array}$ & $\begin{array}{r}1.000 \\
1.000 \\
1.000 \\
.300 \\
1.000 \\
.100 \\
1.000 \\
.050 \\
.100 \\
1.000\end{array}$ & $\begin{array}{l}\text { SF } \\
\text { SF } \\
\text { SF } \\
\text { EA } \\
\text { SF } \\
\text { SF } \\
\text { LB } \\
\text { LF } \\
\text { LF } \\
\text { SF }\end{array}$ & $\begin{array}{r}2.77 \\
.24 \\
1.24 \\
.04 \\
.28 \\
.09 \\
.66 \\
.08 \\
.02 \\
.31\end{array}$ & $\begin{array}{r}7.10 \\
.61 \\
3.92 \\
.10 \\
.20 \\
.27 \\
.62 \\
.04 \\
.26 \\
.40\end{array}$ & $\begin{array}{r}9.87 \\
.85 \\
5.16 \\
.14 \\
.48 \\
.36 \\
1.28 \\
.12 \\
.28 \\
.71\end{array}$ \\
\hline TOTAL & & & 5.73 & 13.52 & 19.25 \\
\hline
\end{tabular}

${ }^{30}$ Adapted from R.S. Means Co., Inc., Means Assemblies Cost Data, 24 ${ }^{\text {th }}$ Annual Edition (Kingston, MA: R.S. Means Co., Inc., 1999), p. 274. 


\subsubsection{Assembly Costs}

The assemblies approach to estimating element costs requires the estimator to add up the assembly costs that constitute an element. Table 4.2 lists the three assembly costs of Element B1010, Floor Construction, for a selected building. The total cost of the assemblies is $\$ 563,640$.

Based on the given quantity of 55,000 SF of Floor Construction, an elemental unit rate of $\$ 10.25 /$ SF can be derived by dividing the $\$ 563,640$ total cost of assemblies by the 55,000 $\mathrm{SF}$ of floor area. The unit rate can be incorporated in a historical data base for directly estimating the cost of similar floors for other buildings.

Table 4.2 Assembly Costs for Floor Construction, Element B1010

\begin{tabular}{|c|c|c|c|c|c|}
\hline $\begin{array}{l}\text { Assembly } \\
\text { Code }\end{array}$ & Description & Quantity & Unit & $\underset{\$}{\text { Rate }}$ & $\begin{array}{l}\text { Assembly } \\
\text { Costs } \\
\$\end{array}$ \\
\hline $3.5-540-3600$ & $\begin{array}{l}\text { Steel Frame With Composite } \\
\text { Deck And Slab, 25' X 30' Spans, } \\
75 \text { PSF }^{\mathrm{a}} \text { Superimposed } \\
\text { Load }\end{array}$ & 55,000 & SF & 9.01 & 495,550 \\
\hline $3.1-130-5800$ & $\begin{array}{l}\text { 12' Steel Columns } \\
400 \mathrm{KIPs}^{\mathrm{b}}\end{array}$ & 986 & $\mathrm{VLF}^{\mathrm{c}}$ & 56.65 & 55,857 \\
\hline $3.1-190-3650$ & Column Fireproofing & 600 & VLF & 20.39 & 12,234 \\
\hline B1010 & Floor Construction & 55,000 & $\mathrm{SF}$ & $10.25^{\mathrm{d}}$ & 563,640 \\
\hline
\end{tabular}

${ }^{\text {a }} \mathrm{PSF}$ is pounds per square foot.

${ }^{\mathrm{b}} \mathrm{KIP}$ is a unit of weight equal to 1000 pounds.

${ }^{\mathrm{c}} \mathrm{VLF}$ is vertical lineal feet.

${ }^{\mathrm{d}}$ The elemental rate of $\$ 10.25 / \mathrm{SF}$ is determined by dividing the total element cost of $\$ 563,640$ by the element quantity $55,000 \mathrm{SF}$.

Note that assembly cost data manuals will in some cases have assemblies that correspond to UNIFORMAT II elements, whereas in other cases several assemblies will have to be combined to construct a UNIFORMAT II elemental cost. 


\subsubsection{Component Costs}

The component approach is similar to the assemblies approach for estimating elemental costs, except that individual component costs are summed to estimate the cost of an element. Chart 4.3 shows how the cost of a $100 \mathrm{MBH}$ heat generation system is calculated from the cost of its individual components, such as the boiler, piping, pumps, insulation, and chimney. The sum of the costs of components for this element is $\$ 7,576.90$.

To calculate a unit rate for estimating costs of similar-sized heat generating systems, divide the $\$ 7,576.90$ by the unit measure $100 \mathrm{MBH}$. This resulting elemental rate of $\$ 75.77$ per $\mathrm{MBH}$ can be incorporated in a historical database for estimating future project costs.

\subsubsection{Units of Measurement}

Suitable units of measurement are needed for estimating elemental costs by multiplying elemental rates times quantities. Furthermore, these units of measurement are an essential part of the historical database of unit rates that will be used in preparing future budgets and estimates. Examples of units of measurement and corresponding unit rates are as follows:

- A1010, Standard Foundations, are measured in square feet of footprint area (FPA). If the cost of element A1010 is $\$ 30,433$ for an FPA of $6,000 \mathrm{SF}$, the unit rate is $\$ 5.07 /$ SF of FPA.

- B3010, Roof Coverings, are measured in square feet of roof area. If the cost is $\$ 17,506$ for a $6,000 \mathrm{SF}$ roof, the rate is $\$ 2.92 / \mathrm{SF}$ of roof area.

- C1010, Partitions, are measured in terms of square feet area of partition area. If the cost of C1010 is $\$ 160,846$ for a quantity of $28,979 \mathrm{SF}$, the unit rate is $\$ 5.55 / \mathrm{SF}$ of partition area.

- D2040, Rain Water Drainage, is measured in square feet of roof area. If the cost of D2040 is $\$ 6,137$ for a 6000 SF roof, the unit rate is $\$ 1.02 / \mathrm{SF}$ of roof area.

- D3030, Cooling Generation, is measured in tons of refrigeration (TR). If the cost of D3030 is $\$ 137,200$ for a 150 ton chilled water cooling system, the rate is $\$ 915 / T R$.

Cost data sources based on appropriate units of measurement are listed in Section 4.7.1. 


\section{Chart 4.3 Component Costs for Element D3020, 100 MBH Heat Generating}

System $^{31}$

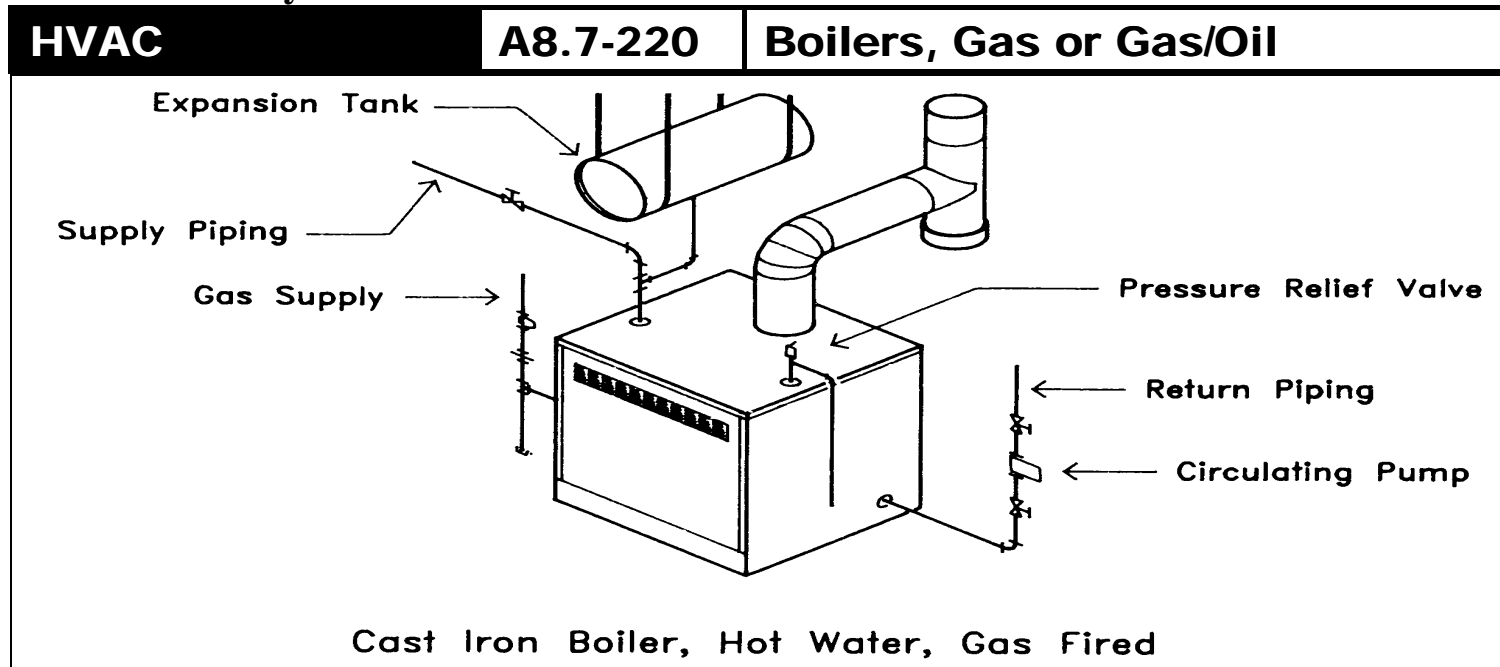

\begin{tabular}{|c|c|c|c|c|c|}
\hline \multirow[b]{2}{*}{ System Components } & \multirow[b]{2}{*}{ Quantity } & \multirow[b]{2}{*}{ Unit } & \multicolumn{3}{|c|}{ \$COST EACH } \\
\hline & & & Mat. & Inst. & Total \\
\hline SYSTEM 8.7-220-1010 & & & & & \\
\hline $\begin{array}{l}\text { Boilers, gas fired, std controls, insulated, } \\
\text { gross output, } 100 \mathrm{MBH}\end{array}$ & 1.000 & EA & $1,350.00$ & $1,125.00$ & $2,475.00$ \\
\hline $\begin{array}{l}\text { Pipe, black steel, Sch } 40 \text {, threaded, W/coupling \& } \\
\text { hangers, } 10^{\prime} 0 \mathrm{C}, 3 / 4^{\prime} \mathrm{dia}\end{array}$ & 20.000 & LF & 31.95 & 146.25 & 178.20 \\
\hline $\begin{array}{l}\text { Pipe, black steel, Sch } 40 \text {, threaded, W/coupling \& } \\
\text { hangers, } 10^{\prime} \text { OC, 1" dia }\end{array}$ & 20.000 & LF & 38.92 & 160.18 & 199.10 \\
\hline Elbow, $90^{\circ}$, black straight, $3 / 4 "$ dia. & 9.000 & EA & 12.15 & 252.00 & 264.15 \\
\hline Elbow, $90^{\circ}$, black straight, 1 "dia. & 6.000 & EA & 14.10 & 183.00 & 197.10 \\
\hline Tee, black, straight, 3/4" dia. & 2.000 & EA & 4.32 & 88.00 & 92.32 \\
\hline Tee, black, straight, 1" dia. & 2.000 & EA & 7.32 & 99.00 & 106.32 \\
\hline Tee, black, reducing, 1" dia. & 2.000 & EA & 8.20 & 99.00 & 107.2 \\
\hline Union, black with brass seat, 1 " dia. & 1.000 & EA & 1.51 & 12.35 & 13.86 \\
\hline Pipe nipples, black, 3/4" dia. & 2.000 & EA & 11.40 & 61.00 & 72.40 \\
\hline Pipe nipples, black, 1 " dia. & 2.000 & EA & 14.70 & 66.00 & 80.70 \\
\hline $\begin{array}{l}\text { Valves, bronze, gate, threaded, class } 150 \text {, } \\
3 / 4 \text { " size }\end{array}$ & 2.000 & EA & 51.00 & 39.50 & 90.50 \\
\hline $\begin{array}{l}\text { Valves, bronze, gate, threaded, class } 150 \text {, } \\
\text { 1" size }\end{array}$ & 2.000 & EA & 66.00 & 42.00 & 108.00 \\
\hline Gas cock, brass, 3/4" size & 1.000 & EA & 11.35 & 17.95 & 29.30 \\
\hline Thermometer, stem type, 9" case, 8 " stem, $3 / 4$ " & 2.000 & EA & 108.00 & 28.30 & 136.30 \\
\hline $\begin{array}{l}\text { Tank, steel, liquid expansion, ASME, painted, } 15 \\
\text { gallon capacity }\end{array}$ & 1.000 & EA & 355.00 & 42.00 & 397.00 \\
\hline $\begin{array}{l}\text { Pump, circulating, bronze, flange connection, } 3 / 4 \text { " to } \\
1-1 / 2 " \text { size, } 1 / 8 \mathrm{HP}\end{array}$ & 1.000 & EA & 570.00 & 119.00 & 689.00 \\
\hline $\begin{array}{l}\text { Vent chimney, all fuel, pressure tight, double wall, } \\
\text { SS, 6"dia. }\end{array}$ & 20.000 & LF & 750.00 & 237.00 & 987.00 \\
\hline Vent chimney, elbow, $90^{\circ}$ fixed, $6 "$ dia. & 2.000 & EA & 426.00 & 47.00 & 473.00 \\
\hline Vent chimney, Tee, 6"dia. & 2.000 & EA & 280.00 & 59.00 & 339.00 \\
\hline Vent chimney, ventilated roof thimble, 6 "dia. & 1.000 & EA & 187.00 & 27.50 & 214.50 \\
\hline Vent chimney, adjustable roof flashing, 6"dia. & 1.000 & EA & 52.00 & 23.50 & 75.50 \\
\hline Vent chimney, stack cap. 6" diameter & 1.000 & EA & 148.00 & 15.45 & 163.45 \\
\hline $\begin{array}{l}\text { Insulation, fiberglass pipe covering, 1" wall, 1" } \\
\text { pipe size }\end{array}$ & 20.000 & $\mathrm{LF}$ & 23.60 & 64.40 & 88.00 \\
\hline TOTAL & & & $4,522.52$ & $3,054.38$ & $7,576.90$ \\
\hline
\end{tabular}

${ }^{31}$ Adapted from R.S. Means Co., Inc., Means Mechanical Cost Data, $22^{\text {nd }}$ Annual Edition (Kingston, MA: R.S. Means Co., Inc., 1999), p. 466. 


\subsection{Cost Analysis Parameters}

Cost analysis parameters developed in building and sitework elemental estimate summaries facilitate analysis, control, and monitoring of costs from the programming phase through design completion. Estimates using MasterFormat 95 ${ }^{\mathrm{TM}}$ Divisions 1-16, based on products and materials, are less effective for these purposes.

Summaries of building elemental cost estimates (as shown in Table 4.3) contain the following cost analysis parameters:

- Building construction cost (BCC) per unit $\mathrm{GFA}^{32}$ that includes all mark-ups.

- Level 3 elemental costs per unit of measurement.

- Level 3 elemental costs per unit of GFA.

- Level 2 group elemental costs per unit of GFA.

- Quantity of element per unit of GFA.

Corresponding parameters for the sitework cost summary are included in Table 4.4.

There are two primary reasons for using cost analysis parameters in evaluating estimates. The first is to analyze and monitor costs, element by element, as design progresses, to ensure that costs are within the allocated budget and within the range of the costs of comparable historical projects with similar quality levels.

The second reason is to identify the likely source of budget overruns as early as possible. This facilitates making revisions to plans and specifications that may be required to meet the budget with minimum impact on the design schedule and design cost.

\subsection{Elemental Cost Estimate Summary Format and Case Illustration}

This section proposes an elemental estimate summary format. It communicates cost information in a concise, consistent manner to the client and project team members. The summary format helps them (1) understand the cost profile of the entire project, (2)analyze costs using analytic parameters, and (3) identify potential cost overruns early to initiate corrective action. We present a case illustration of an elemental estimate for an 8-story office building. Cost data come from several Means Cost Manuals, primarily the 1999 Means Assemblies Cost Data. ${ }^{33}$

\footnotetext{
${ }^{32}$ Note that four of the five cost analysis parameters are based on Gross Floor Area (GFA). Thus, the GFA must be determined in a consistent manner to produce reliable estimates and cost analysis parameters. We have chosen the AIA method of measurement for GFA in this report as described in AIA Document D101-The Architectural Area and Volume of Buildings (Washington, DC: The American Institute of Architects, 1980).

${ }^{33}$ R.S. Means Co., Inc., Means Assemblies Cost Data, 1999.
} 


\subsubsection{Office Building Data}

The example of an elemental estimate is based on an office building with a 6,000 SF footprint area, eight stories above grade level, one basement parking level, and a total GFA of $54,000 \mathrm{SF}$. The total site area is $43,560 \mathrm{SF}$ of which $6,000 \mathrm{SF}$ is the foot print area. The front elevation and plans are shown in Figure 4.1. A preliminary project description (PPD) is shown in Chart 4.4. Note that the elemental PPD is relatively simple and based on Level-2 group elements of UNIFORMAT II.

\section{Figure 4.1 Office Building Plans and Elevation ${ }^{34}$}

\section{Front Elevation}

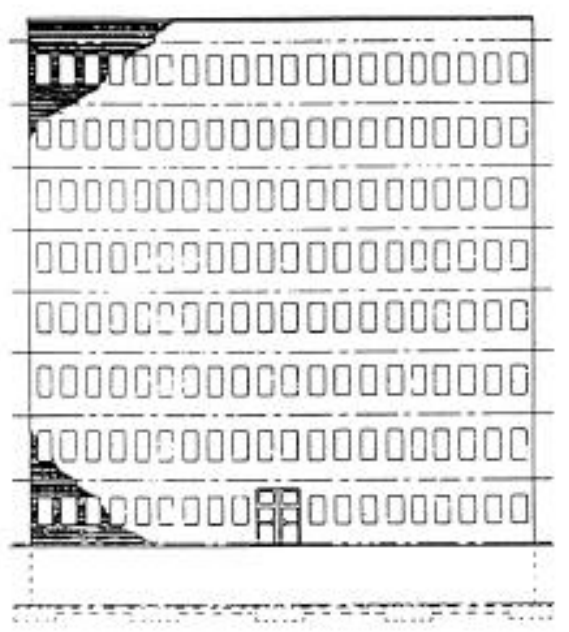

Ground Floor Plan

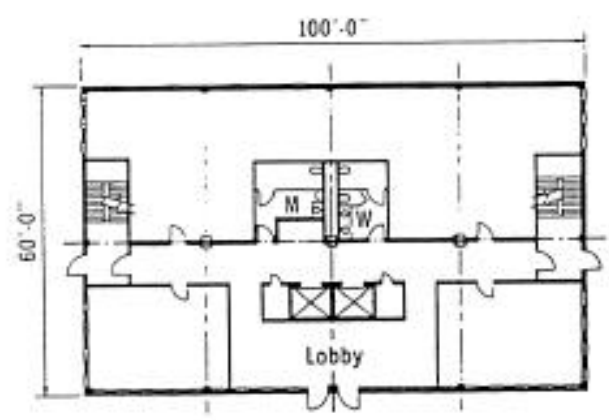

Basement Plan

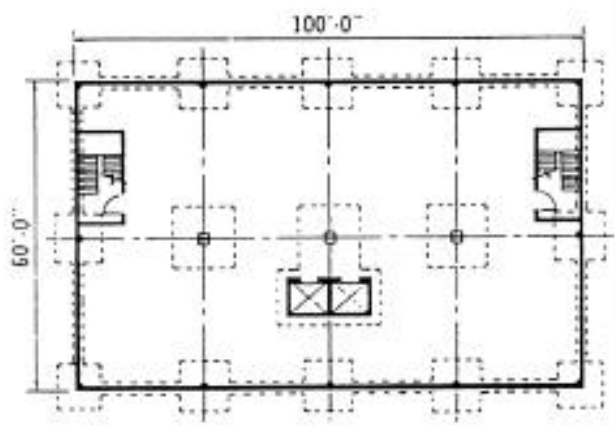

Typical Floor Plan

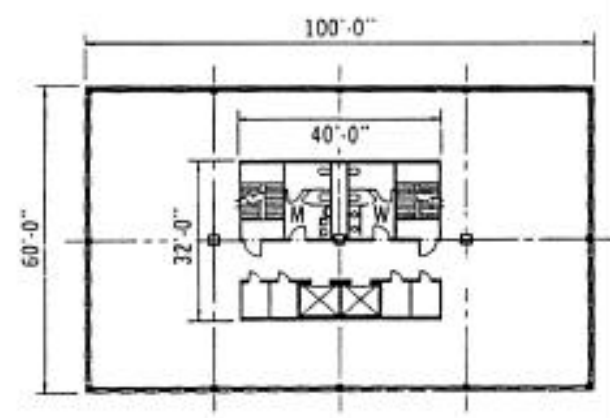

\footnotetext{
${ }^{34}$ R.S. Means Co., Inc., Means Square Foot Costs, $20^{\text {th }}$ Annual Edition (Kingston, MA: R.S. Means Co., Inc., 1999), p. 225.
} 


\section{Chart 4.4 UNIFORMAT II Elemental Project Description (Level 2) - 8 Story Office Building ${ }^{35}$}

GENERAL: Building size - 60' x 100', 8 floors, 12' floor to floor height, 4' high parapet, full basement with 11'8" floor to floor, bay size 25' x 30', ceiling heights are 9' in office area and 8' in core area, 43,560 SF site.

A10 FOUNDATIONS - Concrete spread and strip footings, 4" concrete slab on grade, normal soil conditions.

A20 BASEMENT CONSTRUCTION - 12' high, 12" thick waterproofed basement walls.

B10 SUPERSTRUCTURE - Steel columns, wide flange; 3 hour fire rated; floors, composite steel frame and deck with concrete slab; roof, steel beams, open web joists and deck.

B20 EXTERIOR CLOSURE - Walls; North, East and West, brick and lightweight concrete block with 2" cavity insulation, 25\% window; South, 8" lightweight concrete block insulated, 10\% window. Doors, aluminium and glass at 1st floor level, insulated automatic basement garage door. Windows, aluminium, 3'-0" x 5'-4" insulating glass.

B30 ROOFING — Tar and gravel, 4 ply, 2" rigid insulation, R15; one roof access hatch.

C10 INTERIOR CONSTRUCTION - Core, 6" lightweight concrete block partitions, full height. Corridors - 1st and 2nd floor, 3 5/8" steel studs with fire rated gypsum board, full height steel fabricated toilet partitions. Doors — hollow metal; Specialities — toilet accessories, directory board.

C20 STAIRCASES — Steel with concrete fill.

C30 INTERIOR FINISHES - Wall Finishes: lobby, mahogany panelling on furring, remainder plaster finish to ceiling height (partition and wall surfaces), paint. Floor Finishes: 1st floor lobby, corridors, and toilet rooms, terrazzo, remainder, concrete; tenant developed 2nd thru 8th; toilet rooms, ceramic tiles; office and corridor, carpet. Ceiling Finishes - 24" x 48" fibreglass board on Tee grid.

D10 CONVEYING SYSTEMS — two, 2500 lb capacity, 200 F.P.M., geared elevators, 9 stops.

D20 PLUMBING — Vanity top lavatories, wall hung urinals and water closets; service sinks. Gas fired domestic hot water heater and reservoir; copper distribution piping throughout. Cast iron sanitary waste piping; drains in each washroom floor and parking level. 4" CI roof drains and PVC piping.

D30 HVAC — Cast iron gas-fired $1088 \mathrm{MBH}$ water boiler and 150 ton water-cooled chiller in penthouse. Perimeter hot water finned tube radiation with wall to wall enclosures. 52800 CFM built-up VAV air handling unit for office floors. VAV air supply and low pressure return air distribution. 5500 CFM direct gas-fired parking garage air handling ventilation unit with air supply and exhaust duct systems. Pneumatic control system with central control.

D40 FIRE PROTECTION — Standard sprinkler system in office area; dry sprinklers in basement parking area; 4" standpipe, 9 hose cabinets.

D60 ELECTRICAL - Service, panel board and feeder, 2000 amps. Lighting, 1st thru 8th, 15 fluorescent fixtures / $1000 \mathrm{SF}, 3$ watts/SF. Basement 10 fluorescent fixtures / $1000 \mathrm{SF}, 2$ Watts/ SF. Receptacles 1st thru 8th, 16.5 / 1000 SF, 2 Watts/SF. Basement, 10 receptacles / $1000 \mathrm{SF}, 1.2 \mathrm{Watts} / \mathrm{SF}$. Air conditioning, 4 Watts/SF; miscellaneous connections 1.2 Watts/SF; Elevator power, two, $10 \mathrm{HP} 230$ volt motors; wall switches, 2/1000 SF. Fire detection system, pull stations, signals, smoke and heat detectors. Emergency lighting generator, $30 \mathrm{~kW}$.

E10 EQUIPMENT - Automatic parking garage access gate, dock leveller, waste handling compactor.

E20 FURNISHINGS - Vertical PVC interior blinds for all exterior windows. Washroom vanities.

G SITEWORK - The one acre site (43,560 SF) must be cleared and excavated in part to obtain required elevations; paved parking stalls with barriers and painted lines; shrubs, trees and hydroseeding for landscaping; water supply, sanitary and storm sewers; gas service piping; underground electrical power and cabling in conduit, exterior HPS lighting, duct bank for telephone cabling; lawn sprinkler system.

\footnotetext{
${ }^{35}$ The data in this table came in part from R.S. Means Co., Inc., Means Square Foot Costs, 1999, p. 224.
} 


\subsubsection{Elemental Estimate Cost Summaries}

A major advantage of the elemental estimate summaries presented here is that they provide cost analysis parameters and other information necessary to make a quick initial analysis of costs. This can be done for most elements without having to refer to back-up information contained in the detail sheets.

The estimate cost summaries are presented in three tables ${ }^{36}$ - Table 4.3 for the Building, Table 4.4 for the Sitework, and Table 4.5 for Total Construction Cost. Note that it is important that sitework costs be separated from building costs for meaningful cost analysis.

Table 4.3, UNIFORMAT II Elemental Cost Summary for Buildings, displays the estimated building costs only. It includes design and inflation allowances plus general contractor overhead and profit. The estimated building construction cost (BCC) for the 8 -story building is $\$ 5,461,571$ ( $\$ 101.14 / \mathrm{SF}$ of GFA).

Table 4.4, UNIFORMAT II Elemental Cost Summary for Sitework, displays estimated costs for sitework only. It too includes design and inflation allowances, plus the general contractor overhead and profit. The estimated sitework construction cost (SCC) is $\$ 236,895$ (\$6.31/SF of NSA or net site area).

Table 4.5, Total Construction Cost Summary, lists Level 3 elemental costs without design allowances, design allowances, overhead and profit, and inflation allowances for a total construction cost (TCC) of $\$ 5,698,466$.

\subsubsection{Allowances, Overhead, and Profit}

Construction cost summaries include mark-ups for (1) design allowances (contingencies), (2) the general contractor's overhead and profit (OH\&P), and (3) inflation allowances. Incorporating these mark-ups in a consistent manner within UNIFORMAT II estimates facilitates meaningful comparisons of estimated costs from different projects and different sources.

In Tables 4.3 (buildings) and 4.4 (sitework), all mark-ups are shown with "Z" designators. Note that these designators are not incorporated in the ASTM E1557 standard because E1557 is a classification of building elements only, and not an estimating standard. The " $Z$ " designators in the estimate summaries are the following:

- Design Allowances — Z10 (buildings), Z50(sitework)

\footnotetext{
${ }^{36}$ The estimate cost summary format proposed in this report is incorporated in software available from G/C EMUNI, Inc., www.gcei.ca The three cost summary tables in this report were produced using that software.
} 
These allowances are for additional items or changes that occur as design progresses. The more complex or unique is the project, the higher will be the initial design allowance. Design allowances set at the Programming phase reduce to zero by completion of the Construction Documents stage, when complete project information is available. The costs of major scope changes are not included in this allowance. Major scope changes require additional funding or a change in program requirements.

- Overhead and Profit ${ }^{37}-\mathrm{Z} 20, \mathrm{Z} 60$

Overhead and profit are the general contractor's direct costs and profit that are added to the sum of elemental costs and design allowances. The amount established is a function of the complexity of the project, the construction period, and market conditions.

- Inflation Allowance - Z30, Z70

Inflation allowances cover material and labor cost escalation calculated from the date of the estimate through the completion of construction.

\subsubsection{Detailed Elemental Cost Estimates}

Table 4.6 provides detailed calculations of element costs for the 8-story office building, and Table 4.7 provides detailed calculations for the sitework costs. The total cost, unit of measurement, and quantity of each element are transferred from the detail sheets to the building and sitework summaries in Tables 4.3 and 4.4. Note that these costs are Level-3 elemental costs that include the sub-contractor overhead and profit. As noted previously, the General Contractor's overhead and profit, however, and the design and inflation allowances, are added as "Z" designators in both the building and sitework summary sheets.

The following headings are incorporated in the estimate detail sheets (Table 4.6 for the Building and 4.7 for the Sitework).

- $\quad$ The INPUT CODE of the item. ${ }^{38}$

- The DESCRIPTION of the item.

- $\quad$ The QUANTITY of the item.

\footnotetext{
${ }^{37}$ Elemental Level- 3 costs in the summaries are inclusive of subcontractor overhead and profit. Means' costs manuals include these items.

${ }^{38}$ The input code references the data source from which the unit is taken. R.S. Means Cost Manuals would be one example.
} 
Table 4.3 UNIFORMAT II Elemental Cost Summary for Buildings

\begin{tabular}{|c|c|c|c|c|c|c|c|c|}
\hline \multirow[t]{3}{*}{ Project } & \multicolumn{2}{|c|}{ Example - 8 Story Office Building } & & & & GFA & & $4,000.00 \mathrm{SF}$ \\
\hline & LEVEL 2 GROUP ELEMENTS & Ratio & & & ment & & Cost per & $\%$ \\
\hline & Level 3 Elements & Qty/GFA & Quantity & Unit & Rate & Cost & Unit GFA & \\
\hline A10 & FOUNDATIONS & - & - & & - & $69,726.50$ & 1.29 & $1.6 \%$ \\
\hline A1010 & Standard Foundations & 0.11 & $6,000.00$ & SF & 7.67 & $46,026.50$ & 0.85 & \\
\hline A1020 & Special Foundations & - & - & & - & - & & \\
\hline A1030 & Slab on Grade & 0.11 & 6.000 .00 & $\mathrm{SF}$ & 3.95 & 23.700 .00 & 0.44 & \\
\hline A20 & BASEMENT CONSTRUCTION & - & & & - & 75.467 .20 & 1.40 & $1.7 \%$ \\
\hline A2010 & Basement Excavation & 0.05 & $2,700.00$ & $\mathrm{CY}$ & 5.91 & $15,960.00$ & 0.30 & \\
\hline A2020 & Basement Walls & 0.07 & 3.840 .00 & $\mathrm{SF}$ & 15.50 & $59,507.20$ & 1.10 & \\
\hline B10 & SUPERSTRUCTURE & - & & & - & $688,569.96$ & 12.75 & $15.8 \%$ \\
\hline B1010 & Floor Construction & 0.89 & $48,000.00$ & $\mathrm{SF}$ & 13.37 & $641,632.56$ & 11.88 & \\
\hline B1020 & Roof Construction & 0.11 & 6.000 .00 & $\mathrm{SF}$ & 7.82 & 46.937 .40 & 0.87 & \\
\hline B20 & EXTERIOR ENCLOSURE & & & & & 794.141 .00 & 14.71 & $18.2 \%$ \\
\hline B2010 & Exterior Walls & 0.47 & $25,500.00$ & $\mathrm{SF}$ & 18.43 & 469.900 .00 & 8.70 & \\
\hline B2020 & Exterior Windows & 0.12 & $6,600.00$ & $\mathrm{SF}$ & 47.58 & $314,041.00$ & 5.82 & \\
\hline $\mathrm{B} 2030$ & Exterior Doors & 0.00 & 5.00 & LVS & $2,040.00$ & $10,200.00$ & 0.19 & \\
\hline B30 & ROOFING & - & - & & - & $20,269.00$ & 0.38 & $0.5 \%$ \\
\hline B3010 & Roof Coverings & 0.11 & $6,000.00$ & $\mathrm{SF}$ & 3.25 & $19,472.00$ & 0.36 & \\
\hline B3020 & Roof Openings & 0.00 & 11.30 & $\mathrm{SF}$ & 70.53 & 797.00 & 0.01 & \\
\hline C10 & INTERIOR CONSTRUCTION & - & - & & - & 235.604 .00 & 4.36 & $5.4 \%$ \\
\hline C1010 & Partitions & 0.54 & 28.979 .00 & $\mathrm{SF}$ & 5.37 & 155.653 .80 & 2.88 & \\
\hline C1020 & Interior Doors & 0.00 & 66.00 & EA & 693.50 & $45,771.00$ & 0.85 & \\
\hline C1030 & Fittings & 0.00 & 1.00 & Lot & 34.179 .20 & 34.179 .20 & 0.63 & \\
\hline $\mathrm{C} 20$ & STAIRS & - & - & & - & $120,600.00$ & 2.23 & $2.8 \%$ \\
\hline C2010 & Stair Construction & 0.00 & 18.00 & FLT & 6.700 .00 & $120,600.00$ & 2.23 & \\
\hline $\mathrm{C} 2020$ & Stair Finishes & - & & & - & & & \\
\hline $\mathrm{C30}$ & INTERIOR FINISHES & - & & & - & 325.583 .43 & 6.03 & $7.5 \%$ \\
\hline С3010 & Wall Finishes & 0.81 & 43.484 .00 & SF & 0.90 & 39.125 .68 & 0.72 & \\
\hline C3020 & Floor Finishes & 0.69 & $37,350.00$ & SF & 4.16 & $155,469.75$ & 2.88 & \\
\hline C 3030 & Ceilling Finishes & 0.96 & $52,100.00$ & $\mathrm{SF}$ & 2.51 & $130,988.00$ & 2.43 & \\
\hline D10 & CONVEYING & - & - & & - & $270,000.00$ & 5.00 & $6.2 \%$ \\
\hline D1010 & Elevators \& Lifts & 0.00 & 18.00 & STOP & $15,000.00$ & $270,000.00$ & 5.00 & \\
\hline D1020 & Escalators \& Movina Walks & - & - & & - & - & & \\
\hline D1090 & Other Conveving Svstems & - & - & & - & & & \\
\hline D20 & PLUMBING & - & - & & - & 134.925 .20 & 2.50 & $3.1 \%$ \\
\hline D2010 & Plumbing Fixtures & 0.00 & 78.00 & FIX & $1,007.51$ & $78,586.00$ & 1.46 & \\
\hline D2020 & Domestic Water Distribution & 0.00 & 78.00 & FIX & 334.10 & $26,060.00$ & 0.48 & \\
\hline D2030 & Sanitary Waste & 0.00 & 78.00 & FIX & 312.24 & $24,355.00$ & 0.45 & \\
\hline D2040 & Rain Water Drainage & 0.11 & 6.000 .00 & SF & 0.99 & 5.924 .20 & 0.11 & \\
\hline D2090 & Other Plumbina Svstems & - & $=$ & & - & & & \\
\hline D30 & HVAC & - & - & & - & 752.460 .00 & 13.93 & $17.2 \%$ \\
\hline D3010 & Energv Supply & - & - & & - & & & \\
\hline D3020 & Heat Generating Svstems & 0.02 & $1,088.00$ & MBH & 21.69 & $23,600.00$ & 0.44 & \\
\hline D3030 & Cooling Generating Systems & 0.00 & 150.00 & TR & 985.00 & $147,750.00$ & 2.74 & \\
\hline D3040 & Distribution Systems & 0.89 & $48,000.00$ & SF & 10.01 & $480,600.00$ & 8.90 & \\
\hline D3050 & Terminal \& Package Units & 0.11 & 6.000 .00 & SF & 1.48 & 8.880 .00 & 0.16 & \\
\hline D3060 & Controls and Instrumentation & 1.00 & $54,000.00$ & SF & 1.60 & 86.400 .00 & 1.60 & \\
\hline D3070 & Svstems Testing \& Balancing & 1.00 & 54.000 .00 & $\mathrm{SF}$ & 0.10 & 5.230 .00 & 0.10 & \\
\hline D3090 & Other HVAC Systems \& Equipment & $\ldots$ & & & - & & & \\
\hline D40 & FIRE PROTECTION & - & - & & - & 103.655 .00 & 1.92 & $2.4 \%$ \\
\hline D4010 & Sprinklers & 0.01 & 270.00 & HDS & 308.22 & $83,220.00$ & 1.54 & \\
\hline D4020 & Standpipes & 0.00 & 9.00 & & $2,270.56$ & $20,435.00$ & 0.38 & \\
\hline D4030 & Fire Protection Specialties & - & - & & - & - & & \\
\hline D4090 & Other Fire Protection Svstems & - & - & & - & & & \\
\hline D50 & ELECTRICAL & - & - & & - & 702.805 .00 & 13.01 & $16.1 \%$ \\
\hline D5010 & Electrical Service \& Distribution & 0.01 & 360.00 & $\mathrm{~kW}$ & 242.15 & $87,175.00$ & 1.61 & \\
\hline D5020 & Lighting \& Branch Wiring & 1.00 & $54,000.00$ & SF & 8.64 & $466,380.00$ & 8.64 & \\
\hline D5030 & Communication \& Security & 1.00 & $54,000.00$ & SF & 2.48 & $133,665.00$ & 2.48 & \\
\hline D5090 & Other Electrical Systems & 0.00 & 30.00 & $\mathrm{~kW}$ & 519.50 & $15,585.00$ & 0.29 & \\
\hline E10 & EQUIPMENT & - & - & & - & 17.310 .00 & 0.32 & $0.4 \%$ \\
\hline E1010 & Commercial Equipment & - & - & & - & - & & \\
\hline E1020 & Institutional Equipment & - & - & & - & - & & \\
\hline E1030 & Vehicular Equipment & 0.00 & 1.00 & Lot & $10,655.00$ & $10,655.00$ & 0.20 & \\
\hline E1090 & Other Equipment & 0.00 & 1.00 & Lot & $6,655.00$ & 6.655 .00 & 0.12 & \\
\hline E20 & FURNISHINGS & - & - & & - & $55,716.00$ & 1.03 & $1.3 \%$ \\
\hline E2010 & Fixed Furnishings & 0.00 & 1.00 & Lot & $55,716.00$ & $55,716.00$ & 1.03 & \\
\hline E2020 & Movable Furnishings & - & - & & - & - & & \\
\hline F10 & SPECIAL CONSTRUCTION & - & - & & - & - & & $0.0 \%$ \\
\hline F1010 & Special Structures & - & - & & - & - & & \\
\hline F1020 & Integrated Construction & - & - & & - & - & & \\
\hline F1030 & Special Construction Systems & - & - & & - & - & & \\
\hline F1040 & Special Facilities & - & - & & - & - & & \\
\hline $\mathrm{F} 1050$ & Special Controls and Instrumentation & - & - & & - & - & & \\
\hline F20 & SELECTIVE BUILDING CONSTRUCTION & - & - & & - & - & & $0.0 \%$ \\
\hline F2010 & Building Elements Demolition & - & - & & - & - & & \\
\hline $\mathrm{F} 2020$ & Hazardous Components Abatement & - & - & & - & - & & \\
\hline & Building & ithout Desic & wance & & & $4,366.832 .29$ & 80.87 & $100.00 \%$ \\
\hline $\mathrm{Z10}$ & Desian Allowance & & & & $6.00 \%$ & $262,009.94$ & 4.85 & \\
\hline & Building & ith Desian. & & & & 4.628 .842 .23 & 85.72 & $106.00 \%$ \\
\hline $\mathrm{Z20}$ & Overhead \& Profit & & & & $14.00 \%$ & $648,037.91$ & 12.00 & \\
\hline Z2010 & Overhead & & & & $9.00 \%$ & $416,595.80$ & 7.71 & \\
\hline $\mathrm{Z2020}$ & Profit & & & & $5.00 \%$ & $231,442.11$ & 4.29 & \\
\hline & Building & without In & & & & $5,276,880.14$ & 97.72 & $120.84 \%$ \\
\hline $\mathrm{Z30}$ & Inflation Allowance & & & & $3.50 \%$ & $184,690.80$ & 3.42 & \\
\hline & & CC) & & & & 5.461 .570 .94 & 101.14 & $125.07 \%$ \\
\hline
\end{tabular}


Table 4.4 UNIFORMAT II Elemental Cost Summary for Sitework

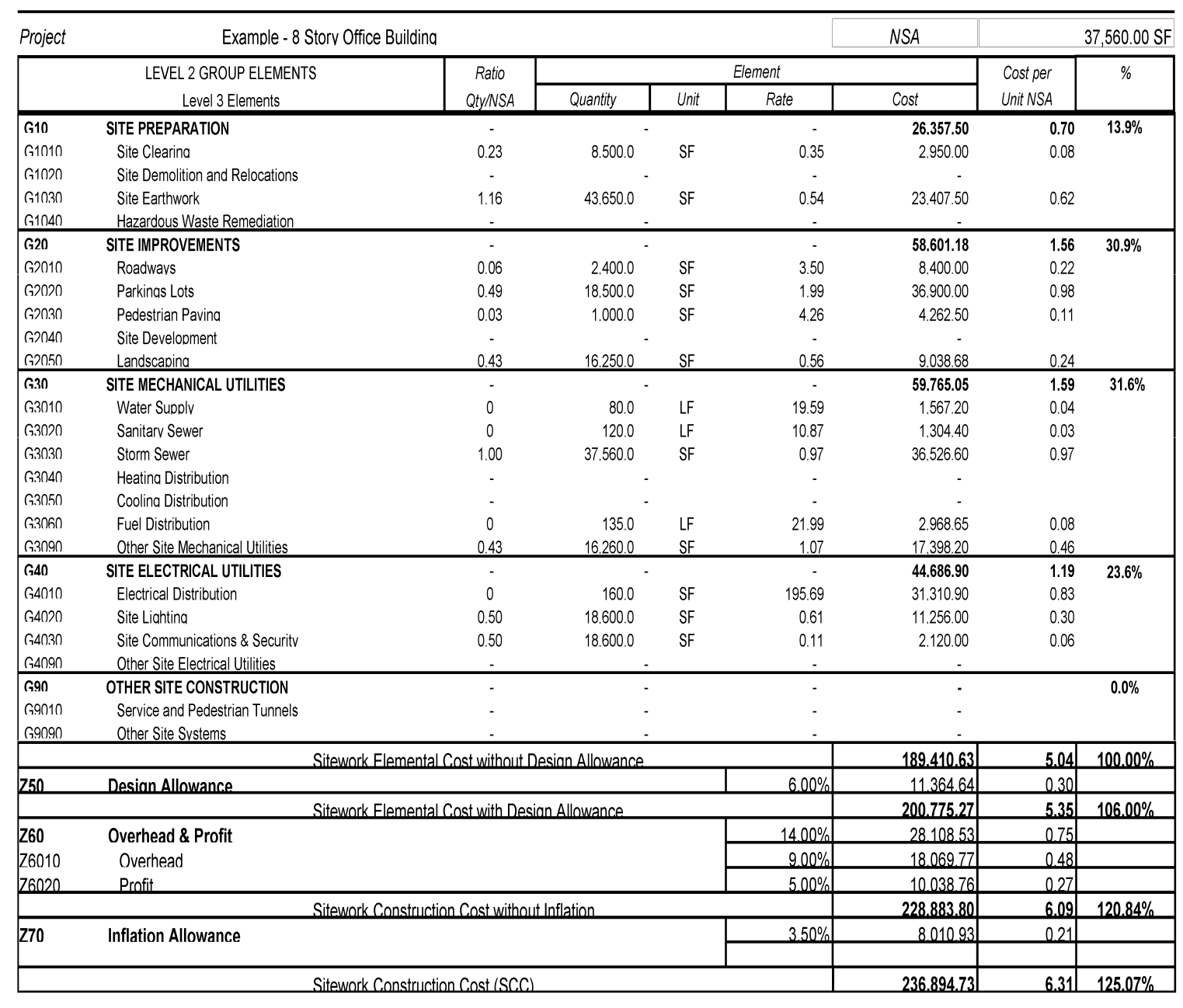

Table 4.5 Total Construction Cost Summary (TCC)

\begin{tabular}{|l|r|r|r|r|r|r|}
\hline & \multicolumn{2}{|c|}{ Building } & \multicolumn{2}{c|}{ Sitework } & \multicolumn{2}{c|}{ Total } \\
\cline { 2 - 7 } & \multicolumn{1}{|c|}{ Cost } & \multicolumn{1}{c|}{$\%$} & \multicolumn{1}{c|}{ Cost } & \multicolumn{1}{c|}{ Cost } & \multicolumn{1}{c|}{$\%$} \\
\hline Elemental Cost without Design Allowance & $\$ 4,366,832.29$ & $76.6 \%$ & $\$ 189,410.63$ & $3.3 \%$ & $\$ 4,556,242.92$ & $80.0 \%$ \\
Design Allowance & $\$ 262,009.94$ & $4.6 \%$ & $\$ 11,364.64$ & $0.2 \%$ & $\$ 273,374.58$ & $4.8 \%$ \\
Overhead \& Profit & $\$ 648,037.91$ & $11.4 \%$ & $\$ 28,108.53$ & $0.5 \%$ & $\$ 676,146.44$ & $11.9 \%$ \\
Inflation Allowance & $\$ 184,690.80$ & $3.2 \%$ & $\$ 8,010.93$ & $0.1 \%$ & $\$ 192,701.73$ & $3.4 \%$ \\
\hline Total Construction Cost (TCC) & $\$ 5,461,570.94$ & $95.8 \%$ & $\$ 236,894.73$ & $4.2 \%$ & $\$ 5,698,465.67$ & $100 \%$ \\
\hline
\end{tabular}


Table 4.6 Detailed Elemental Cost Estimates for Buildings

\begin{tabular}{|c|c|c|c|c|c|c|}
\hline Project & Example - 8 Story Office Building & & & & & \\
\hline Input Code & Description & Quantity & Unit & Rate & Cost & Output Code \\
\hline A & SUBSTRUCTURE & & & - & $145,193.70$ & \\
\hline A10 & FOUNDATIONS & & & . & $69,726.50$ & \\
\hline A1010 & Standard Foundations & $6,000.0$ & SF & 7.67 & $46,026.50$ & \\
\hline A01.1-120-7900 & Corner Spread ftgs, Id 400K, soil cap 6 KSF, 8'-6" sq $\times 27^{\prime \prime} d$ & 4.0 & $E A$ & $1,360.00$ & $5,440.00$ & \\
\hline A01.1-120-8010 & Exterior Spread ftgs, Id 500K, soil cap 6 KSF, 9'-6" sq × 30"d & 8.0 & $E A$ & $1,820.00$ & $14,560.00$ & \\
\hline A01.1-120-8300 & Interior Spread ftgs, Id 800K, soil cap 6 KSF, 12'-0" sq X 37"d & 3.0 & $E A$ & $3,400.00$ & $10,200.00$ & \\
\hline A01.1-140-2700 & Strip footing, load 11.1KLF, 24"wide x 12"deep, reinf & 210.0 & $\mathrm{LF}$ & 26.45 & $5,554.50$ & \\
\hline A01.1-294-3000 & Foundation underdrain, outside and inside, PVC, 4" diameter & 640.0 & LF & 16.05 & $10,272.00$ & \\
\hline A1020 & Special Foundations & & & . & & \\
\hline A1030 & Slab on Grade & $6,000.0$ & SF & 3.95 & $23,700.00$ & \\
\hline A02.1-200-2240 & Slab on grade, 4 " thick, non industrial, reinforced & $6,000.0$ & SF & 3.60 & $21,600.00$ & \\
\hline $07.2-109-0600$ & Perimeter under slab insulation - polystyrene 1", R4 & $2,800.0$ & SF & 0.75 & $2,100.00$ & \\
\hline A20 & BASEMENT CONSTRUCTION & & & . & $75,467.20$ & \\
\hline A2010 & Basement Excavation & $2,700.0$ & cy & 5.91 & $15,960.00$ & \\
\hline A01.9-100-3440 & Basement Excav \& backill, 12 ' deep, sand, gravel, on site storage & $6,000.0$ & SF & 2.66 & $15,960.00$ & \\
\hline A2020 & Basement Walls & $3,840.0$ & SF & 15.50 & $59,507.20$ & \\
\hline A01.1-210-7260 & Basement Fdn walls, CIP, 12' height,pumped, $12^{\prime \prime}$ thick & 320.0 & LF & 168.00 & $53,760.00$ & \\
\hline A01.1-292-2800 & Basement Foundation dampproofing, bituminous, 2 coats, 12 high & 320.0 & $\mathrm{LF}$ & 12.44 & $3,980.80$ & \\
\hline 07.2-109-0700 & Basement Wall insulation - polystyrene 2", R8 & $1,920.0$ & LF & 0.92 & $1,766.40$ & \\
\hline B & SHELL & & & . & $1,502,979.96$ & \\
\hline$B 10$ & SUPERSTRUCTURE & & & . & $688,569.96$ & \\
\hline B1010 & Floor Construction & $48,000,0$ & SF & 13.37 & $641,632.56$ & \\
\hline A03.5-540-3600 & Floor, Composite bm, dk\&slb,25x30',75 PSF superimposed load & $48,000.0$ & SF & 10.94 & $525,120.00$ & \\
\hline A03.1-130-5800 & Steel columns,400 KIPS,10' unsupported height & $1,296.0$ & VLF & 76.50 & $99,144.00$ & \\
\hline A03.1-190-3650 & Steel column fireproofing,gyp bd $1 / 2^{\mathrm{Nf} f}$ & 792.0 & VLF & 21.93 & $17,368.56$ & \\
\hline$B 1020$ & Roof Construction & $6,000.0$ & SF & 7.82 & $46,937.40$ & \\
\hline A03.7-420-3900 & Roof - Open Web Joists, Beams \& deck,25x30',4OPSF superimposed load & $6,000.0$ & SF & 4.87 & $29,220.00$ & \\
\hline A03.1-130-5800 & Steel columns,400 KIPS, $10^{\prime}$ unsupported height & 180.0 & VLF & 76.50 & $13,770.00$ & \\
\hline A03.1-190-3650 & Steel column fireproofing,gyp bd $1 / 2^{\mathrm{ff} f}$ & 180.0 & VLF & 21.93 & $3,947.40$ & \\
\hline B20 & EXTERIOR ENCLOSURE & & & . & $794,141.00$ & \\
\hline B2010 & Exterior Walls & $25,500.0$ & SF & 18.43 & $469,900,00$ & \\
\hline A04.1-273-1200 & 4" Brick Wall \& 6" Block clw Insulation & $16,500.0$ & SF. & 19.80 & $326,700.00$ & \\
\hline A04.1-211-3410 & 8" Conc block wall clw styrofoam insulation & $9,000.0$ & SF & 9.46 & $85,140.00$ & \\
\hline A04.1-140-6776 & Precast Concrete Coping - 14" wide & 320.0 & $\mathrm{LF}$ & 25.25 & $8,080.00$ & \\
\hline A06.1-680-0920 & Gypsum plaster, 2 coats & $24,500.0$ & SF & 2.04 & $49,980,00$ & \\
\hline B2020 & Exterior Windows & $6,600.0$ & SF & 47.58 & $314,041.00$ & \\
\hline A04.7-110-8800 & Alu. Windows \& Insulated glass,3'-0" x 5'-4" & 406.0 & $E A$ & 773.50 & $314,041.00$ & \\
\hline B2030 & Exterior Doors & 5.0 & LVS & $2,040.00$ & $10,200,00$ & \\
\hline A04.6-100-6300 & Single Alu. \& Glass Door c/w hardware,3'-0"x 7'-0"opng & 2.0 & $E A$ & $1,870.00$ & $3,740.00$ & \\
\hline
\end{tabular}


Table 4.6 Detailed Elemental Cost Estimates for Buildings (cont.)

\begin{tabular}{|c|c|c|c|c|c|c|}
\hline Project & Example - 8 Story Office Building & & & & & \\
\hline Input Code & Description & Quantity & Unit & Rate & Cost & Output Code \\
\hline A04.6-100-6950 & Double Alu \& G Glass Door ciw hardware,6'-0" x 10'-0" opng & 1.0 & $E A$ & $3,550.00$ & $3,550.00$ & \\
\hline A046.-100-5100 & Overhead Electric Garage Door, 10:0" x 10'0" opening clw hardware & 1.0 & $E A$ & $2,910.00$ & $2,910.00$ & \\
\hline$\underline{B} 30$ & ROOFING & & & - & $20,269.00$ & \\
\hline B3010 & Roof Coverings & $6,000.0$ & $\mathrm{SF}$ & 3.25 & 19,472.00 & \\
\hline A05.1-103-1400 & Built-up Roof, 4 ply, \#15asph felt, mopped & $6,000.0$ & SF & 1.65 & $9,900.00$ & \\
\hline A05.1-620-0300 & Flashing,aluminum,fabric backing, 2 sides & 640.0 & SF & 2.30 & $1,472.00$ & \\
\hline A05.7-101-4020 & Insulation,composites w/1-1/2" polyisocyanurate, 1 " perlite & $6,000.0$ & $\mathrm{SF}$ & 1.35 & $8,100.00$ & \\
\hline B3020 & Roof Openings & 11.3 & $\mathrm{SF}$ & 70.53 & 797.00 & \\
\hline A05.8-100-0500 & Roof hatches, w/curb \&1" "fog insul, 2'-6"x4'-6" & 1.0 & $E A$ & 797.00 & 797.00 & \\
\hline$\underline{c}$ & INTERIORS & & & . & $681,787,43$ & \\
\hline $\mathrm{C} 10$ & INTERIOR CONSTRUCTION & & & . & $235,604.00$ & \\
\hline C1010 & Partitions & $28,979.0$ & $\mathrm{SF}$ & 5.37 & $155,653.80$ & \\
\hline A06.1-210-5500 & Core partitions - lightweight, hollow,6" thick Concrete Block & $26,449.0$ & SF & 5.60 & $148,114.40$ & \\
\hline A06.1-510-5400 & Corridor Partitions, metal stud \& FR drywall & $2,530.0$ & $\mathrm{SF}$ & 2.98 & $7,539.40$ & \\
\hline C1020 & Interior Doors & 66.0 & $E A$ & 693.50 & $45,771.00$ & \\
\hline A06.4-220-1020 & Interior Door wFFrame \& without Hardware & 66.0 & $E A$ & 597.00 & $39,402.00$ & \\
\hline A06.4-292-0220 & Hinges & 66.0 & $E A$ & 25.50 & $1,683.00$ & \\
\hline A06.4-292-0360 & Locksets & 66.0 & $E A$ & 71.00 & $4,686.00$ & \\
\hline C1030 & Fittings & 1.0 & Lot & $34,179.20$ & $34,179.20$ & \\
\hline A06.1-870-0700 & Tollet partitions, cubicles, floor mounted,plastic laminate - fabricated & 31.0 & $E A$ & 680.00 & $21,080.00$ & \\
\hline A06.1-870-0760 & Toilet partitions, handicap addition & 16.0 & $E A$ & 292.00 & $4,672.00$ & \\
\hline A11.1-100-1100 & Bathroom acc., Towel dispenser, surface mtd & 16.0 & $E A$ & 61.00 & 976.00 & \\
\hline A11.1-100-1200 & Bathroom acc., grab bar, 1-1/14" diam, 12" Ing & 32.0 & $E A$ & 51.70 & $1,654.40$ & \\
\hline A11.1-100-1300 & Bathroom acc., Mirroir with shelf, 18" × 24" & 31.0 & $E A$ & 114.10 & $3,537.10$ & \\
\hline A11.1-100-1400 & Bathroom acc., Toletet tissue disp, surf mtd, sgl roll & 31.0 & $E A$ & 22.70 & 703.70 & \\
\hline A11.1-100-2100 & Bathroom acc. Directory boards, indoor, 18" $124 "$ & 8.0 & $E A$ & 194.50 & $1,556.00$ & \\
\hline C20 & STAIRS & & & . & $120,600.00$ & \\
\hline$C 2010$ & Stair Construction & 18.0 & FLT & $6,700.00$ & $120,600.00$ & \\
\hline A03.9-100-0760 & Stairs, steel w/ concretet fill, 20 risers, with landing & 18.0 & FLT & $6,700.00$ & $120,600.00$ & \\
\hline C2020 & Stair Finishes & & & . & & \\
\hline C30 & INTERIOR FINISHES & & & . & $325,583.43$ & \\
\hline C3010 & Wall Finishes & $43,484.0$ & $\mathrm{SF}$ & 0.90 & $39,125.68$ & \\
\hline A06.5-100-0080 & Paining, int on plaster and drywall, primer \& 2 coats & $42,134.0$ & SF & 0.77 & $32,443.18$ & \\
\hline A06.1-580-0652 & Lobby- Furring for Mohoganny Paneling, wood strips, 1" X3", 12" OC & $1,350.0$ & $\mathrm{SF}$ & 0.97 & $1,309.50$ & \\
\hline A06.5-100-1662 & Lobby - Mahogany, Paneling, prefinished plywood & $1,350.0$ & $\mathrm{SF}$ & 3.98 & $5,373.00$ & \\
\hline C3020 & Floor Finishes & $37,350.0$ & $\mathrm{SF}$ & 4.16 & $155,469.75$ & \\
\hline A06.6-100-0060 & Carpet, 2402 & $33,075.0$ & SF & 3.69 & $122,046.75$ & \\
\hline A06.6-100-1100 & Terrazzo, 1st Floor, Corridor \& Tolet Room & $2,175.0$ & $\mathrm{SF}$ & 8.00 & $17,400.00$ & \\
\hline A06.6-100-1720 & CeramicTile, natural clay & 2,1000 & SF & 7.63 & $16,023.00$ & \\
\hline
\end{tabular}


Table 4.6 Detailed Elemental Cost Estimates for Buildings (cont.)

\begin{tabular}{|c|c|c|c|c|c|c|}
\hline Project & Example -8 Story Office Building & & & & & \\
\hline Input Code & Description & Quantity & Unit & Rate & Cost & Output Code \\
\hline C3030 & Ceilling Finishes & $52,100.0$ & SF & 2.51 & $130,988.00$ & \\
\hline A06.7-810-3260 & T-bar suspension system, 2 ' $\times 4^{\prime}$ grid & $41,600.0$ & SF & 0.80 & $33,280.00$ & \\
\hline A06.7-810-2780 & Suspended Ceiling - Mineral fiber boards, $5 / 8$ "thick, 2 hour rating & $41,600.0$ & SF & 1.43 & $59,488.00$ & \\
\hline A06.7-100-5400 & Drywall,1/2"ff & $10,500.0$ & SF & 2.87 & $30,135.00$ & \\
\hline A06.5-100-0080 & Painting, interior on drywall, primer \& 2 coats & $10,500.0$ & SF & 0.77 & $8,085.00$ & \\
\hline D & SERVICES & & & . & $1,963,845.20$ & \\
\hline D10 & CONVEYING & & & . & $270,000,00$ & \\
\hline D1010 & Elevators \& Lifts & 18.0 & STOP & $15,000.00$ & $270,000.00$ & \\
\hline A07.1-200-1600 & Elevator - Traction gearless, $2500 \mathrm{lb}, 9$ floors, $200 \mathrm{FPM}$ (interpolation) & 2.0 & $E A$ & $135,000.00$ & $270,000.00$ & \\
\hline D1020 & Escalators \& Moving Walks & & & $\cdot$ & & \\
\hline D1090 & Other Conveying Systems & & & . & & \\
\hline D20 & PLUMBING & & & . & $134,925.20$ & \\
\hline D2010 & Plumbing Fixtures & 78.0 & FIX & $1,007.51$ & $78,586,00$ & \\
\hline A08.1-433-1560 & Lavatory w/trim, vanity top, $20 " \times 18 "$ & 31.0 & $E A$ & 656.00 & $20,336.00$ & \\
\hline A08.1-434-4340 & Service sink w/trim, 24" $\times 20 "$ & 8.0 & $E A$ & $1,480.00$ & $11,840.00$ & \\
\hline A08.1-450-2000 & Urinal, wall hung & 8.0 & $E A$ & 880.00 & $7,040.00$ & \\
\hline A08.1-470-2080 & Water Closet, wall hung & 31.0 & $E A$ & $1,270.00$ & $39,370.00$ & \\
\hline D2020 & Domestic Water Distribution & 78.0 & FIX & 334.10 & $26,060,00$ & \\
\hline A08.1-160-1940 & Electric water heater, $120 \mathrm{gal}, 36 \mathrm{KW} 147 \mathrm{GPH}$ & 1.0 & $E A$ & $5,125.00$ & $5,125.00$ & \\
\hline R8.1-030 & Allowance for piping ( $22.5 \%$ of fixture cost D2010) & 1.0 & Lot & $20,935.00$ & $20,935.00$ & \\
\hline D2030 & Sanitary Waste & 78.0 & $F \mid X$ & 312.24 & $24,355.00$ & \\
\hline $15.1-100-0840$ & Floor Drain - 3" dia. & 20.0 & $E A$ & 171.00 & $3,420.00$ & \\
\hline R8.1-030 & Allowance for piping ( $22.5 \%$ of fixture cost D2010) & 1.0 & Lot & $20,935.00$ & $20,935.00$ & \\
\hline D2040 & Rain Water Drainage & $6,000.0$ & SF & 0.99 & $5,924.20$ & \\
\hline A08.1-310-4200 & Roof Drain System, Cl, soil,single hub,4" diam, 10' high & 2.0 & $E A$ & 860.00 & $1,720.00$ & \\
\hline A08.1-310-4240 & Roof drain, additional foot & 196.0 & LF & 21.45 & $4,204.20$ & \\
\hline$\underline{D 2090}$ & Other Plumbing Systems & & & - & & \\
\hline D30 & HVAC & & & - & $752,460.00$ & \\
\hline D3010 & Energy Supply & & & $\cdot$ & & \\
\hline D3020 & Heat Generating Systems & $1,088.0$ & $\mathrm{MBH}$ & 21.69 & $23,600,00$ & \\
\hline A08.7-220-1070 & Boiler, cast iron, gas, hot water, $1088 \mathrm{MBH}$ c/w circulating pump & 1.0 & $E A$ & $23,600.00$ & $23,600.00$ & \\
\hline D3030 & Cooling Generating Systems & 150.0 & TR & 985.00 & $147,750,00$ & \\
\hline A08.8-110-1030 & Chiller, reciprocating, water cooled, std. controls, 150 ton & 1.0 & $E A$ & $103,000.00$ & $103,000.00$ & \\
\hline A08.5-414-1040 & Chilled Water Pump, base mid w/ motor, 5 " size, $10 \mathrm{HP}$, (interpolation) & 1.0 & $E A$ & $10,600.00$ & $10,600.00$ & \\
\hline A08.8-160-1020 & Cooling tower, galvanized steel, packaged unit, draw thru, 150 ton (interpolation) & 1.0 & EA & $25,250.00$ & $25,250.00$ & \\
\hline A08.5-414-1030 & Cooling Tower Pump, base mtd with motor, 4" size, 7-1/2 HP, to 350 GPM & 1.0 & $E A$ & $8,900.00$ & $8,900.00$ & \\
\hline D3040 & Distribution Systems & $48,000.0$ & SF & 10.01 & $480,600,00$ & \\
\hline A08.3-142-3400 & Hot Water heating distribution, fin tube radiation (interpolation) & $48,000.0$ & SF & 4.35 & $208,800.00$ & \\
\hline A08.4-120-4000 & Cooling air distribution supply and return air ducts clw devices (interpolation) & $48,000.0$ & SF & 4.20 & $201,600.00$ & \\
\hline
\end{tabular}


Table 4.6 Detailed Elemental Cost Estimates for Buildings (cont.)

\begin{tabular}{|c|c|c|c|c|c|c|}
\hline Project & Example - 8 Story Office Builling & & & & & \\
\hline Input Code & Description & Quantity & Unit & Rate & Cost & Output Code \\
\hline A08.8-310-1010 & Air Handling Unit, field fab, VAV coollheat, clw return air, 52,800 CFM (interpolation) & 1.0 & $E A$ & $70,200.00$ & $70,200.00$ & \\
\hline D3050 & Terminal \& Package Units & $6,000.0$ & SF & 1.48 & 8,880000 & \\
\hline 15.5-461-0160 & Direct Gas Fired 6000 CFM, 500 MBH, Parking Garage Make up air Unit & 1.0 & $E A$ & $7,400.00$ & $7,400.00$ & \\
\hline R155-020 & Allowance for gas \& vent piping ( $20.0 \%$ of unit cost $)$ & 1.0 & Lot & $1,480.00$ & $1,480.00$ & \\
\hline D3060 & Controls and Instrumentation & $54,000.0$ & SF & 1.60 & $86,400,00$ & \\
\hline R155-021 & Allowance for controls \& instrumentation & $54,000.0$ & SF & 1.60 & $86,400.00$ & \\
\hline D3070 & Systems Testing \& Balancing & $54,000.0$ & SF & 0.10 & $5,230.00$ & \\
\hline $\mathrm{R} 155-022$ & Allowance for balancing of HVAC Systems $-0.5 \%$ system cosits & 1.0 & Lot & $5,230.00$ & $5,230.00$ & \\
\hline D3090 & Other HVAC Systems \& Equipment & & & - & & \\
\hline D40 & FIRE PROTECTION & & & . & $103,655.00$ & \\
\hline D4010 & Sprinklers & 270.0 & HDS & 308.22 & $83,220.00$ & \\
\hline A08.2-110-0600 & First Office Floor - Wet pipe sprinkler system & $6,000.0$ & SF & 2.01 & $12,060.00$ & \\
\hline A08.2-110-0720 & Seven add. Office Floors - Wet pipe sprinkler system & $42,000.0$ & SF & 1.33 & $55,860.00$ & \\
\hline A08.2-120-1060 & Basement Parking - Dry pipe sprinkler system & $6,000.0$ & SF & 2.55 & $15,300.00$ & \\
\hline D4020 & Standpipes & 9.0 & & 2,270.56 & $20,435.00$ & \\
\hline A08.2-310-0560 & Wet standpipe risers, class I 4" diam pipe, 1 fl & 1.0 & $\mathrm{FLR}$ & $3,700.00$ & $3,700.00$ & \\
\hline A08.2-310-0580 & Wet standpipe risers, class I 4 " diam pipe, add lfis & 8.0 & $\mathrm{FLR}$ & $1,130.00$ & $9,040.00$ & \\
\hline A08.2-390-8400 & Fire Cabinet assy & 9.0 & $E A$ & 855.00 & $7,695.00$ & \\
\hline D4030 & Fire Protection Specialties & & & . & & \\
\hline D4090 & Other Fire Protection Systems & & & . & & \\
\hline D50 & ELECTRICAL & & & . & $702,805.00$ & \\
\hline D5010 & Electrical Service \& Distribution & 360.0 & kW & 242.15 & $87,175.00$ & \\
\hline A09.1-210-0560 & 3ph, 4 W, 1201208V, 2000 A Service & 1.0 & $E A$ & $29,175.00$ & $29,175.00$ & \\
\hline A09.1-310-0560 & 2000 amperes Feeder & 50.0 & $\mathrm{LF}$ & 356.00 & $17,800.00$ & \\
\hline A09.1-410-0400 & 2000 amperes Switchgear & 1.0 & $E A$ & $40,200.00$ & $40,200.00$ & \\
\hline 05020 & Lighting \& Branch Wiring & $54,000.0$ & SF & 8.64 & $466,380.00$ & \\
\hline A09.2-213-0240 & Basement- Fluor fixture, $40 \mathrm{FC}, 10$ xktt per $1000 \mathrm{SF}$ & $6,000.0$ & SF & 3.44 & $20,640.00$ & \\
\hline A09.2-522-0560 & Basement - Receptacles, 10 per 1000 SF, $1.2 \mathrm{~W}$ per SF & $6,000.0$ & SF & 2.17 & $13,020.00$ & \\
\hline A09.2-213-0280 & Office Floors - Fluor fixture $60 \mathrm{FC}, 15$ fxtr per $1000 \mathrm{SF}$ & $48,000.0$ & SF & 5.17 & $248,160.00$ & \\
\hline A09.2-522-0640 & Office - Receptacles, 16.5 per 1000 SF, $2.0 \mathrm{~W}$ per SF & $48,000.0$ & SF & 2.87 & $137,760.00$ & \\
\hline A09.2-542-0280 & Wall switches, 2.0 per $1000 \mathrm{SF}$ & $54,000.0$ & SF & 0.27 & $14,580.00$ & \\
\hline A09.2-582-0320 & Miscellaneous connections, 1.2 wattls/SF & $54,000.0$ & SF & 0.19 & 10,260.00 & \\
\hline A09.2-710-0680 & Elevator Motor - $10 \mathrm{HP}$ & 2.0 & $E A$ & $2,100.00$ & 4,20000 & \\
\hline A09.2-610-0280 & Central air conditioning power, 4 watts/SF & $48,000.0$ & SF & 0.37 & $17,760.00$ & \\
\hline 05030 & Communication \& Security & $54,000.0$ & SF & 2.48 & $133,665.00$ & \\
\hline A09.4-100-0400 & Fire Detection System - 50 detectors & 1.0 & $E A$ & $21,825.00$ & $21,825.00$ & \\
\hline A09.4-150-0560 & Telephone systems, telepoles, high density & $48,000.0$ & S.F. & 2.33 & $111,840.00$ & \\
\hline D5090 & Other Electrical Systems & 30.0 & kW & 519.50 & $15,585.00$ & \\
\hline A09.4-310-0320 & Emergency Generator Set, 30KW & 30.0 & kW & 519.50 & $15,585.00$ & \\
\hline
\end{tabular}


Table 4.6 Detailed Elemental Cost Estimates for Buildings (cont.)

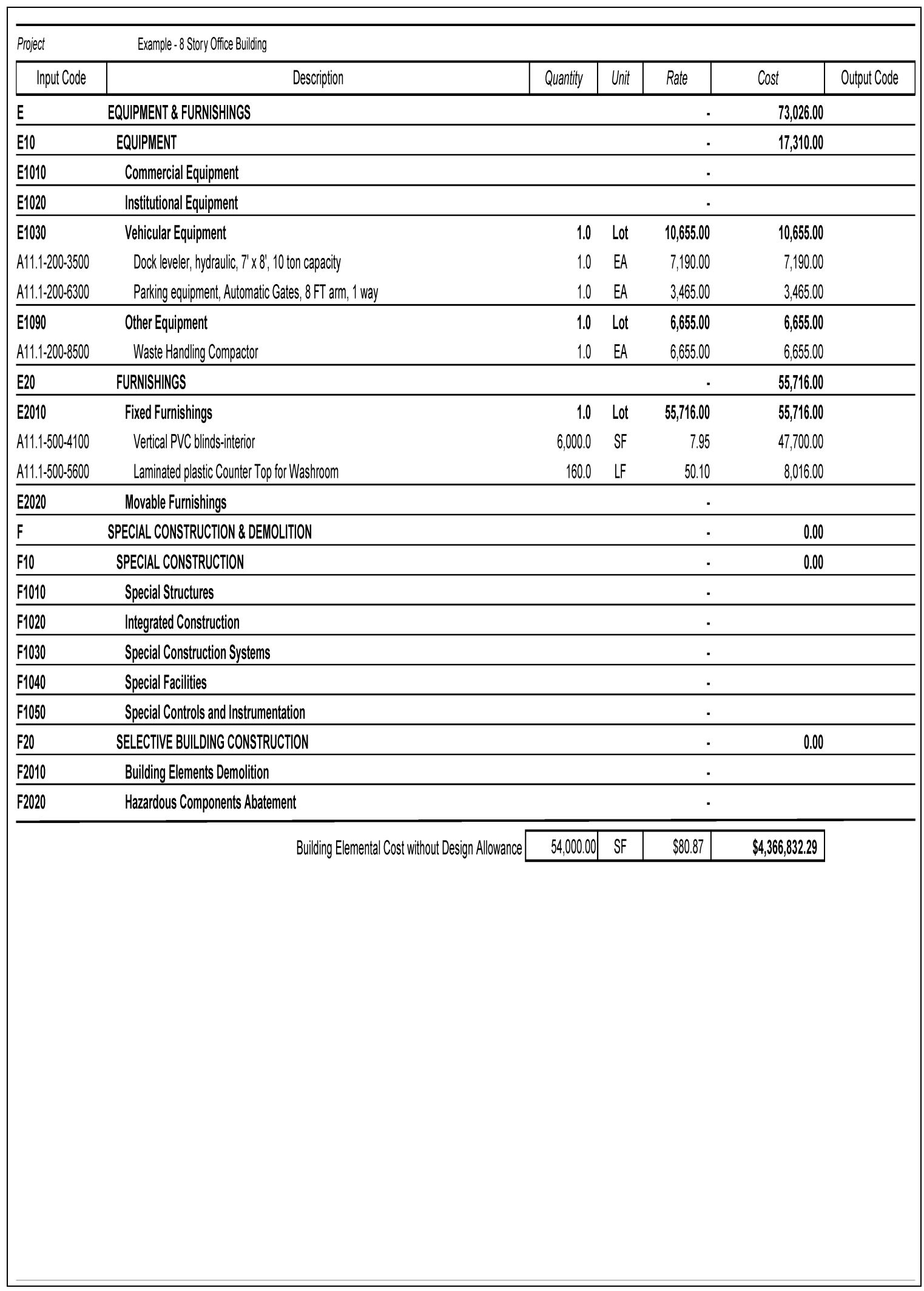


Table 4.7 Detailed Elemental Cost Estimates for Sitework

\begin{tabular}{|c|c|c|c|c|c|c|}
\hline Project & Examole - 8 Story Office Building & & & & & \\
\hline Input Code & Description & Quantity & Unit & Rate & Cost & Output Code \\
\hline$G$ & BUILDNG SITEWORK & & & . & $189,410,63$ & \\
\hline G10 & SITE PREPARATION & & & . & $26,357.50$ & \\
\hline G1010 & Site Clearing & $8,500.0$ & SF & 0.35 & $2,950.00$ & \\
\hline 02.1-104-0150 & Clearing \& grubing & 1.0 & Acre & $1,300.00$ & $1,300.00$ & \\
\hline $02.1-116-0570$ & Tree \& Stump Removal, 75 to 100\% hardwood & 0.3 & Acre & $5,500.00$ & $1,650.00$ & \\
\hline G1020 & Site Demolition and Relocations & & & $0^{\circ}$ & & \\
\hline G1030 & Site Earthwork & $43,650.0$ & SF & 0.54 & $23,407,50$ & \\
\hline $02.2-242-2020$ & Site Earth Excavation, common earth & 5,5000 & $\mathrm{CY}$ & 2.02 & $11,110.00$ & \\
\hline $02.2-266-0400$ & Hauling & 1,0000 & $\mathrm{CY}$ & 4.13 & $4,130.00$ & \\
\hline $02.2-262-1000$ & Fill & 75.0 & CY & 22.50 & $1,687.50$ & \\
\hline $02.2204-2200$ & Backill and compacting, 6 " to 12 " lits & $3,000.0$ & CY & 2.16 & $6,480.00$ & \\
\hline G1040 & Hazardous Waste Remediation & & & . & & \\
\hline G20 & SITE IMPROVEMENTS & & & . & $58,601.18$ & \\
\hline G2010 & Roadways & $2,400.0$ & SF & 3.50 & $8,400.00$ & \\
\hline A12.5-110-1800 & Roadways, bituminous paving, $3^{\prime \prime}$ thick, $20^{\prime}$ wide & 120.0 & $\mathrm{LF}$ & 70.00 & $8,400.00$ & \\
\hline G2020 & Parkings Lots & $18,500.0$ & SF & 1.99 & $36,900,00$ & \\
\hline A12.5.510-1500 & 90< angle Parking, 3" bituminous paving, ciw Wheel Stop \& Painted lines & 82.0 & CAR & 450.00 & $36,900.00$ & \\
\hline G2030 & Pedestrian Paving & 1,0000 & SF & 4.26 & $4,262.50$ & \\
\hline A12.7-140-2140 & Concrete sidewalk, 6 " thick concrete, 4 ' wide & 250.0 & $\mathrm{LF}$ & 17.05 & $4,262.50$ & \\
\hline G2040 & Site Development & & & . & & \\
\hline G2050 & Landscaping & $16,250.0$ & SF & 0.56 & $9,038.68$ & \\
\hline $02.9-304-1000$ & Hydro Seeding, incl seed and fertillzer & $1,807.0$ & SF & 0.24 & 433.68 & \\
\hline 02.9-524-0400 & Shrubs, boxwood, 15"-18" & 100.0 & $E A$ & 16.15 & $1,015.00$ & \\
\hline $02.9-536-1600$ & Trees, Maple, red, 8'-10' & 30.0 & $E A$ & 233.00 & $6,990.00$ & \\
\hline G30 & SITE MECHANICAL UTLLTIES & & & . & $59,765.05$ & \\
\hline$\overline{G 3010}$ & Water Supply & 80.0 & LF & 19.59 & $1,567.20$ & \\
\hline A12.3-110-1330 & Trenching, excavation \& backfill, 4' deeep & 80.0 & LF & 4.14 & 331.20 & \\
\hline A12.3-540-2150 & Water distribution piping,excav \& backf excl, 6"diam & 80.0 & LF & 15.45 & $1,236.00$ & \\
\hline G3020 & Sanitary Sewer & 120.0 & LF & 10.87 & $1,304.40$ & \\
\hline A12.3-110-1330 & Trenching, excavation \& backfll, 4' deep & 120.0 & LF & 4.14 & 496.80 & \\
\hline A12.3.510-2150 & Drainage and sewage piping, PVC, 6 " diam & 120.0 & LF & 6.73 & 807.60 & \\
\hline G3030 & Storm Sewer & $37,560.0$ & SF & 0.97 & $36,526.60$ & \\
\hline A12.3-110-3840 & Trenching, excavation \& backfill, 4' deep & 720.0 & LF & 10.15 & $7,308.00$ & \\
\hline A12.3.510-2160 & Drainage and sewage piping, PVC, 8" diam & 320.0 & LF & 6.83 & $2,185.60$ & \\
\hline A12.3.510-4600 & Drainage \& sewage piping, concrete reinf., $15^{\prime \prime}$ diam & 400.0 & LF & 21.30 & $8,520.00$ & \\
\hline A12.3.710-5840 & Manholelcatch basin, concrete, precast,4' ID riser, $0^{\prime}$ deep & 3.0 & EA & $1,995.00$ & $5,985.00$ & \\
\hline A12.7-610-2600 & Concrete, curb and gutter, monolithic, $6 "$ high, 30 " wide & 720.0 & LF & 17.40 & $12,528.00$ & \\
\hline G3040 & Heating Distribution & & & . & & \\
\hline G3050 & Cooling Distribution & & & . & & \\
\hline
\end{tabular}


Table 4.7 Detailed Elemental Cost Estimates for Sitework (cont.)

\begin{tabular}{|c|c|c|c|c|c|c|}
\hline Project & Example- 8 Story Office Building & & & & & \\
\hline Input Code & Description & Quantity & Unit & Rate & Cost & Output Code \\
\hline G3060 & Fuel Distribution & 135.0 & LF & 21.99 & $2,968.65$ & \\
\hline A12.3-110-1330 & Trenching, excavation \& backfill,4' deep & 135.0 & LF & 4.14 & 558.90 & \\
\hline A12.3-520-3130 & Gas service piping, sched ule40, 4" diam & 135.0 & LF & 17.85 & $2,409.75$ & \\
\hline G3090 & Other Site Mechanical Utilities & $16,260.0$ & SF & 1.07 & $17,398.20$ & \\
\hline 02.8-104-0900 & Sprinkler irigation system, 1-121" supply & $16,260.0$ & SF & 1.07 & $17,398.20$ & \\
\hline G40 & SITE ELECTRICAL UTLLTIES & & & - & $44,686.90$ & \\
\hline G4010 & Electrical Distribution & 160.0 & LF & 195.69 & $31,310.90$ & \\
\hline 02.2-258-3100 & Excavating, 16" wide trench and backfill, 24" deep & 160.0 & $\mathrm{LF}$ & 0.79 & 126.40 & \\
\hline 16.7-110.5800 & Elec \& tel sitewk, ugnd duct, PVC, $6 @ 4$ 4" dia & 160.0 & $\mathrm{LF}$ & 23.00 & $3,680.00$ & \\
\hline 16.1-810-0360 & Grounding wire, bare copper wire, \#6 & 10.6 & CLF & 67.50 & 715.50 & \\
\hline 16.1-810-1240 & Grounding wire, stranded, $500 \mathrm{kcmil}$ & 31.7 & CLF & 770.00 & $24,409.00$ & \\
\hline 16.7-110-7830 & Concrete for Electric \& telephone sitework, underground duct banks & 14.0 & $\mathrm{CY}$ & 170.00 & $2,380.00$ & \\
\hline G4020 & Site Lighting & $18,600.0$ & SF & 0.61 & $11,256.00$ & \\
\hline 16.0-205-9120 & Conduit PVC, 1" diameter & 400.0 & $\mathrm{LF}$ & 4.15 & $1,660.00$ & \\
\hline $16.1-165-5500$ & Wire, 600 volt, copper type XLPE-USE(RHW), stranded, \#8 & 17.0 & CLF & 80.00 & $1,360.00$ & \\
\hline 16.6-170-0450 & Photoelectric control, $2081277 \mathrm{~V}$ & 1.0 & $E A$ & 256.00 & 256.00 & \\
\hline A12.7.500-2320 & Site lighting, HPS 400 watt, alu. pole, 20 'high & 4.0 & EA & $1,995.00$ & $7,980.00$ & \\
\hline G4030 & Site Communications \& Security & 150.0 & LF & 14.13 & $2,120.00$ & \\
\hline 02.2-258-3100 & Excavating, $16 "$ wide trench and backill, 24" deep & 150.0 & $\mathrm{LF}$ & 0.79 & 118.50 & \\
\hline 16.7-110-5000 & Elec \& tel sitewk, ugnd duct, PVC, 2 @ 3" dia (by Telephone Co.) & 150.0 & LF & 5.75 & 862.50 & \\
\hline $16.7-110-7830$ & Concretet for Electric \& telephone sitework, underground duct banks & 6.7 & $\mathrm{CY}$ & 170.00 & $1,139.00$ & \\
\hline G4090 & Other Site Electrical Utilities & & & . & & \\
\hline G90 & OTHER SITE CONSTRUCTION & & & - & 0.00 & \\
\hline G9010 & Service and Pedestrian Tunnels & & & . & & \\
\hline$G 9090$ & Other Site Systems & & & - & & \\
\hline & Sitework Elemental Cost without Design Allowance & $37,560.00$ & SF & $\$ 5.04$ & $\$ 189,410.63$ & \\
\hline
\end{tabular}


- The UNIT of measurement of the item.

- The RATE or cost per unit of the item.

- The COST of the item.

- The OUTPUT CODE for sorting line item costs into other breakdowns, such as by MasterFormat $95^{\mathrm{TM}}$; by construction trades, bid packages, or functional areas; or by other cost organizing principles. This code is blank in Tables 4.6 and 4.7 because at the early stage of design, which these tables portray, the assemblies and elements have not yet been designed in detail.

Table 4.8, taken from the detail sheets of Table 4.6, illustrates the elemental cost calculations for A1010 Standard Foundations. The "INPUT CODE" and cost data come from the 1999 "Assemblies Cost Data." ${ }^{39}$ The last row of the Table shows the total elemental cost for the five assemblies listed to be $\$ 46,026.50$, the total "QUANTITY" to be 6,000 SF footprint area, and the rate for the element to be $\$ 7.67$ per SF. Note that these amounts were transferred from the detail sheet to Table 4.3, the Building Elemental Cost Summary.

Table 4.8 Elemental Cost Calculations for Element A1010, Standard Foundations

\begin{tabular}{|c|c|c|c|c|c|}
\hline $\begin{array}{l}\text { INPUT } \\
\text { CODE }\end{array}$ & DESCRIPTION & QUANTITY & UNIT & $\begin{array}{l}\text { RATE } \\
\$\end{array}$ & $\underset{\$}{\mathrm{COST}}$ \\
\hline $\begin{array}{l}\text { AO1.1-120- } \\
7900\end{array}$ & $\begin{array}{l}\text { Corner Spread } \\
\text { Footings }\end{array}$ & 4 & EA & $1,360.00$ & $5,440.00$ \\
\hline $\begin{array}{l}\text { AO1.1-120- } \\
8010\end{array}$ & $\begin{array}{l}\text { Exterior Spread } \\
\text { Footings }\end{array}$ & 8 & EA & $1,820.00$ & $14,560.00$ \\
\hline $\begin{array}{l}\text { AO1.1-120- } \\
8300\end{array}$ & $\begin{array}{l}\text { Interior Spread } \\
\text { Footings }\end{array}$ & 3 & EA & $3,400.00$ & $10,200.00$ \\
\hline $\begin{array}{l}\text { AO1.1-140- } \\
2700\end{array}$ & Strip Footings & 210 & $\mathrm{LF}$ & 26.45 & $5,554.50$ \\
\hline $\begin{array}{l}\text { AO1.1-294- } \\
3000\end{array}$ & $\begin{array}{l}\text { Foundation } \\
\text { Underdrain }\end{array}$ & 640 & $\mathrm{LF}$ & 16.05 & $10,272.00$ \\
\hline A1010 & $\begin{array}{l}\text { Standard } \\
\text { Foundations }\end{array}$ & 6,000 & $\begin{array}{c}\text { SF } \\
\text { FPA }\end{array}$ & 7.67 & $46,026.50$ \\
\hline
\end{tabular}

${ }^{39}$ R. S. Means Co., Inc., Means Assemblies Cost Data, 1999. 


\subsection{Converting UNIFORMAT II Estimates to MasterFormat $95^{\mathrm{TM}}$}

Elemental formats can be tied to product formats. For example, the elements of the original UNIFORMAT have been related to the CSI MasterFormat ${ }^{\mathrm{TM}}$ for a specific design, as shown in Chart 4.5. It is drawn from Chapter B5, "Design and Construction Cost Management," of the American Institute of Architects Handbook of Professional Practice (1984). ${ }^{40}$ This mapping of one format to the other is useful in converting pre-bid elemental estimates to MasterFormat 95 ${ }^{\mathrm{TM}}$ Divisions 1-16, and from there to the trade costs of the project. A publication ${ }^{41}$ that lists product and material codes for elements is available to facilitate this conversion.

\subsection{Sources of Elemental Cost, Engineering, and Design Data}

\subsubsection{Elemental Cost Data}

Elemental cost data structured according to UNIFORMAT or UNIFORMAT II is available in the following publications:

- $\quad$ Means Assemblies Cost Data, 24 ${ }^{\text {th }}$ Annual Edition, 1999, R. S. Means, Co. Inc., Kingston, MA

- $\quad$ Means Facilities Maintenance and Repair Cost Data, $7^{\text {th }}$ Annual Edition, 1999, R. S. Means Co. Inc., Kingston, MA

- The Assemblies Sections of the following Annual Means Publications

- Means 1999 Electrical Cost Data

- Means 1999 Interior Cost Data

- Means 1999 Mechanical Cost Data

- Means 1999 Plumbing Cost Data

- Means 1999 Residential Cost Data

- Means 1999 Sitework and Landscape Cost Data

- Means 1999 Square Foot Costs

- Hanscomb's 1999 Yardsticks for Costing (Composite Unit Rate SectionCanadian Institute of Quantity Surveyors Format)

- Dell'Isola and Kirk, Life-Cycle Costing for Design Professionals ${ }^{42}$

- The Whitestone Building Maintenance and Repair Cost Reference: $1999^{43}$

\footnotetext{
${ }^{40}$ Table 6.1 also appeared in General Services Administration Handbook PBS P 3440.5, Project Estimating Requirements, August 24, 1981. Note that it is based on UNIFORMAT — not UNIFORMAT II.

${ }^{41}$ Construction Specifications Institute, UniFormat ${ }^{\mathrm{TM}}$ : A Uniform Classification of Construction Systems and Assemblies (Alexandria, VA: The Construction Specifications Institute, 1998 Edition).

${ }^{42}$ Dell'Isola, A.J. and Kirk, S.J., Life Cycle Costing for Design Professionals-2 ${ }^{\text {nd }}$ Edition (New York, NY: McGraw-Hill, Inc., 1995).

${ }^{43}$ Whitestone Research, The Whitestone Building Maintenance and Repair Cost Reference (Santa Barbara, CA: Whitestone Research Corporation, 1999).
} 


\section{Chart 4.5 Relationship of UNIFORMAT to MasterFormat ${ }^{\mathrm{TM}}$}

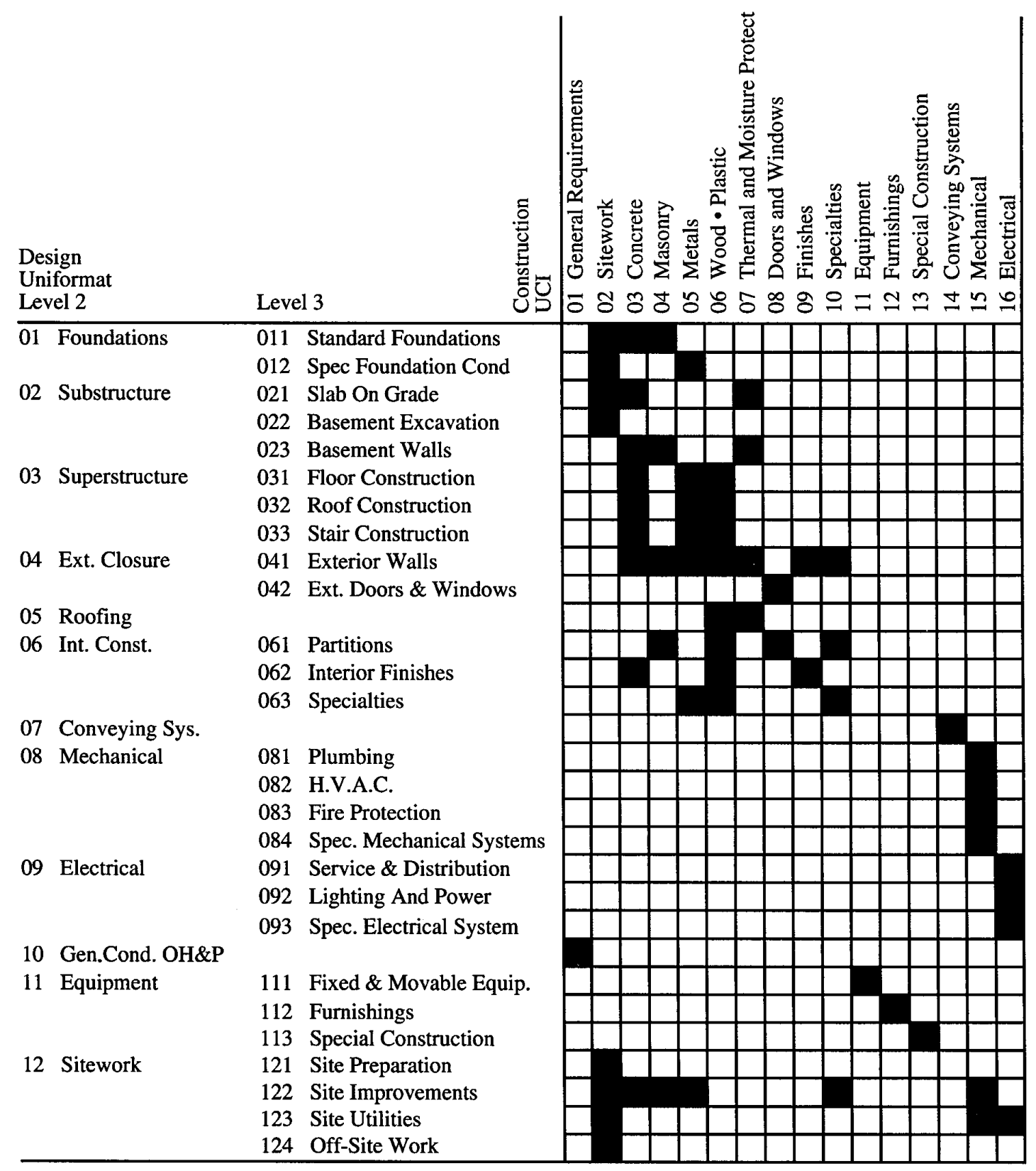

Note: CSI's MasterFormat has superseded the UCI (Uniform Construction Index).

Source: The American Institute of Architects, "Chapter B5, Design and Construction Management, "Architect's Handbook of Professional Practice (Washington, DC: American Institute of Architects, 1984), p.6. 


\subsubsection{Engineering and Design Data}

The following publications have engineering and design data structured according to UNIFORMAT or UNIFORMAT II.

- Cox and Horsley, $\underline{\text { Square Foot Estimating Methods. }} .{ }^{44}$

- Killingsworth, Cost Control in Building Design. ${ }^{45}$

- $\quad$ Means Assemblies Cost Data, Reference Section, $24^{\text {th }}$ Annual Edition 1999, R.S. Means Co. Inc., Kingston, MA.

- Means Building Construction Cost Data, Reference Section, $57^{\text {th }}$ Annual Edition 1997, R.S. Means Co. Inc., Kingston, MA.

- $\quad$ Means Graphic Construction Standards, 1986, R.S. Means Co., Inc., Kingston, MA

- McGraw-Hill Time Saver Standards for Architectural Design, $7^{\text {th }}$ ed., McGraw Hill, 1997.

${ }^{44}$ Cox, B.J. and Horsley, William, Square Foot Estimating Methods, $2^{\text {nd }}$ Edition (Kingston, MA: R.S. Means Co., Inc., 1995).

${ }^{45}$ Killingsworth, Roger, Cost Control in Building Design (Kingston, MA: R.S. Means Co., Inc., 1988). 


\section{Recommended Level-4 Classification}

ASTM's UNIFORMAT II incorporates three hierarchical levels. Some users of UNIFORMAT have felt the need, however, for a fourth level of sub-elements. We used the lists of exclusions and inclusions in Appendix B associated with Level-3 descriptions as a starting point to construct and formalize a suggested UNIFORMAT II Level-4 breakdown. The Level-4 sub-elements are presented in Charts 5.1 for buildings and 5.2 for sitework.

The Level-4 sub-elements are based in part on the original UNIFORMAT Level-4 subelements ${ }^{46}$ and the Tri-Services TRACES Work Breakdown Structure (WBS). Standardizing Level 4 has the following advantages.

Better Cost Data-Increasing the number of designators in the classification by adding an additional level facilitates the development of more comprehensive databases, thereby providing more information for cost estimating and cost control. For example, this broader framework of classification will help estimators to prepare more accurate and detailed estimates, and reduce the magnitude of allowances and contingencies. Project descriptions can be more specific with the addition of the recommended 274 designators for the building and 128 for the sitework.

Consistency-Expansion of UNIFORMAT II to 4 levels ensures consistency as to where items belong. For example, without Level 4 , there is ambiguity as to whether the interior finish to exterior walls belongs to B2010 (Exterior Walls) or C3010 (Wall Finishes). Knowing that an item consistently goes to a specific element category will reduce labor costs of estimating and improve coordination among users of UNIFORMAT II.

More Comprehensive Historical Database-Having a deeper hierarchy of data for a given stock of buildings will strengthen the validation of current cost estimates against the costs of similar buildings constructed in the past.

Interface with MasterFormat 95 $\mathrm{TM}$-Level-3 elements are general in character. A more detailed level of description is needed to relate UNIFORMAT II elements to MasterFormat 95 ${ }^{\mathrm{TM}}$. For example, in the case of B3010, Roof Coverings, Level 4 would categorize several components that would map directly to MasterFormat $95^{\mathrm{TM}}$, including the membrane, vapor retarder, and insulation.

Preliminary Construction Schedules-Preliminary elemental construction schedules can be prepared in more detail during early design because construction tasks can be defined in more detail with Level-4 sub-elements. The more detailed schedule is useful in establishing cash flow requirements for the project since construction costs can be established for sub-elements of the project.

\footnotetext{
${ }^{46}$ Hanscomb Associates, Inc., Automated Cost Control \& Estimating System (Washington, DC: General Services Administration, 1975).
} 


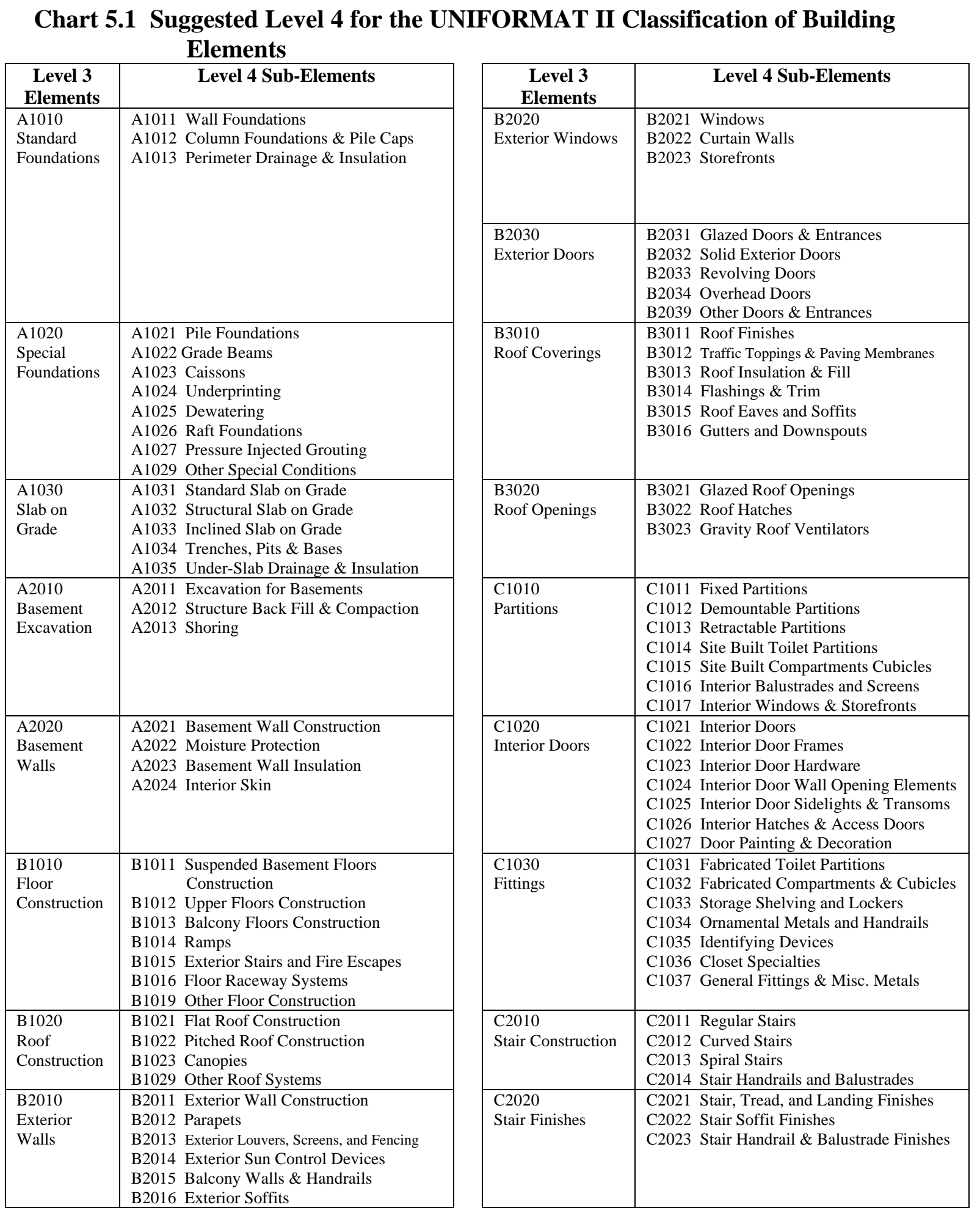




\begin{tabular}{|c|c|}
\hline $\begin{array}{l}\text { C3010 } \\
\text { Wall } \\
\text { Finishes }\end{array}$ & $\begin{array}{l}\text { C3011 Wall Finishes to Inside Exterior } \\
\text { Walls } \\
\text { C3012 Wall Finishes to Interior Walls } \\
\text { C3013 Column Finishes }\end{array}$ \\
\hline $\begin{array}{l}\text { C3020 } \\
\text { Floor } \\
\text { Finishes }\end{array}$ & $\begin{array}{ll}\text { C3021 } & \text { Floor Toppings } \\
\text { C3022 } & \text { Traffic Membranes } \\
\text { C3023 } & \text { Hardeners and Sealers } \\
\text { C3024 } & \text { Flooring } \\
\text { C3025 } & \text { Carpeting } \\
\text { C3026 } & \text { Bases, Curbs and Trim } \\
\text { C3027 } & \text { Access Pedastal Flooring }\end{array}$ \\
\hline $\begin{array}{l}\text { C3030 } \\
\text { Ceiling } \\
\text { Finishes }\end{array}$ & $\begin{array}{ll}\text { C3031 } & \text { Ceiling Finishes } \\
\text { C3032 } & \text { Suspended Ceilings } \\
\text { C3033 } & \text { Other Ceilings }\end{array}$ \\
\hline $\begin{array}{l}\text { D1010 } \\
\text { Elevators \& } \\
\text { Lifts }\end{array}$ & $\begin{array}{ll}\text { D1011 } & \text { Passenger Elevators } \\
\text { D1012 } & \text { Freight Elevators } \\
\text { D1013 } & \text { Lifts }\end{array}$ \\
\hline $\begin{array}{l}\text { D1020 } \\
\text { Escalators \& } \\
\text { Moving } \\
\text { Walks }\end{array}$ & $\begin{array}{l}\text { D1021 Escalators } \\
\text { D1022 Moving Walks }\end{array}$ \\
\hline $\begin{array}{l}\text { D1090 } \\
\text { Other } \\
\text { Conveying } \\
\text { Systems }\end{array}$ & $\begin{array}{ll}\text { D1091 } & \text { Dumbwaiters } \\
\text { D1092 } & \text { Pneumatic Tube Systems } \\
\text { D1093 } & \text { Hoists \& Cranes } \\
\text { D1094 } & \text { Conveyors } \\
\text { D1095 } & \text { Chutes } \\
\text { D1096 Turntables } \\
\text { D1097 } & \text { Baggage Handling \& Loading } \\
& \text { Systems } \\
\text { D1098 } & \text { Transportation Systems }\end{array}$ \\
\hline $\begin{array}{l}\text { D2010 } \\
\text { Plumbing } \\
\text { Fixtures }\end{array}$ & 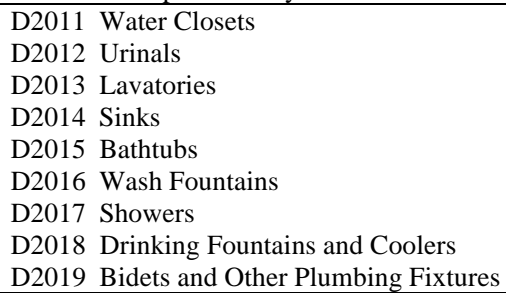 \\
\hline $\begin{array}{l}\text { D2020 } \\
\text { Domestic } \\
\text { Water } \\
\text { Distribution }\end{array}$ & $\begin{array}{l}\text { D2021 Cold Water Service } \\
\text { D2022 Hot Water Service } \\
\text { D2023 Domestic Water Supply Equipment }\end{array}$ \\
\hline $\begin{array}{l}\text { D2030 } \\
\text { Sanitary } \\
\text { Waste }\end{array}$ & $\begin{array}{ll}\text { D2031 } & \text { Waste Piping } \\
\text { D2032 Vent Piping } \\
\text { D2033 Floor Drains } \\
\text { D2034 } & \text { Sanitary Waste Equipment } \\
\text { D2035 Pipe Insulation }\end{array}$ \\
\hline $\begin{array}{l}\text { D2040 } \\
\text { Rain Water } \\
\text { Drainage }\end{array}$ & $\begin{array}{l}\text { D2041 Pipe \& Fittings } \\
\text { D2042 Roof Drains } \\
\text { D2043 Rainwater Drainage Equipment } \\
\text { D2044 Pipe Insulation }\end{array}$ \\
\hline
\end{tabular}

\begin{tabular}{|c|c|}
\hline $\begin{array}{l}\text { D2090 } \\
\text { Other Plumbing } \\
\text { Systems }\end{array}$ & $\begin{array}{l}\text { D2091 Gas Distribution } \\
\text { D2092 Acid Waste Systems } \\
\text { D2093 Interceptors } \\
\text { D2094 Pool Piping and Equipment } \\
\text { D2095 Decorative Fountain Piping Devices } \\
\text { D2099 Other Piping Systems }\end{array}$ \\
\hline $\begin{array}{l}\text { D3010 } \\
\text { Energy Supply }\end{array}$ & $\begin{array}{ll}\text { D3011 } & \text { Oil Supply System } \\
\text { D3012 } & \text { Gas Supply System } \\
\text { D3013 } & \text { Coal Supply System } \\
\text { D3014 } & \text { Steam Supply System } \\
\text { D3015 } & \text { Hot Water Supply System } \\
\text { D3016 } & \text { Solar Energy System } \\
\text { D3017 } & \text { Wind Energy System } \\
\end{array}$ \\
\hline $\begin{array}{l}\text { D3020 } \\
\text { Heat Generating } \\
\text { Systems }\end{array}$ & $\begin{array}{ll}\text { D3021 } & \text { Boilers } \\
\text { D3022 } & \text { Boiler Room Piping \& Specialties } \\
\text { D3023 } & \text { Auxiliary Equipment } \\
\text { D3024 } & \text { Insulation } \\
\end{array}$ \\
\hline $\begin{array}{l}\text { D3030 } \\
\text { Cooling } \\
\text { Generating } \\
\text { Systems }\end{array}$ & $\begin{array}{l}\text { D3031 Chilled Water Systems } \\
\text { D3032 Direct Expansion Systems }\end{array}$ \\
\hline $\begin{array}{l}\text { D3040 } \\
\text { Distribution } \\
\text { Systems }\end{array}$ & $\begin{array}{ll}\text { D3041 } & \text { Air Distribution Systems } \\
\text { D3042 } & \text { Exhaust Ventilation Systems } \\
\text { D3043 } & \text { Steam Distribution Systems } \\
\text { D3044 } & \text { Hot Water Distribution } \\
\text { D3045 } & \text { Chilled Water Distribution } \\
\text { D3046 Change-over Distribution System } \\
\text { D3047 Glycol Distribution Systems }\end{array}$ \\
\hline $\begin{array}{l}\text { D3050 } \\
\text { Terminal \& } \\
\text { Package Units }\end{array}$ & $\begin{array}{l}\text { D3051 Terminal Self-Contained Units } \\
\text { D3052 Package Units }\end{array}$ \\
\hline $\begin{array}{l}\text { D3060 } \\
\text { Controls \& } \\
\text { Instrumentation }\end{array}$ & 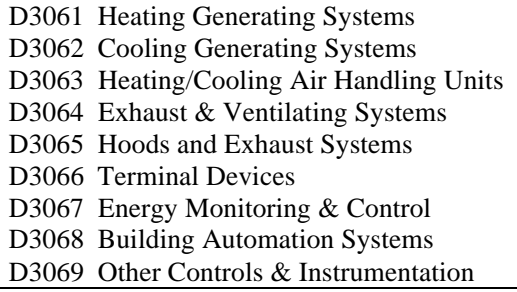 \\
\hline $\begin{array}{l}\text { D3070 } \\
\text { Systems Testing \& } \\
\text { Balancing }\end{array}$ & $\begin{array}{l}\text { D3071 Piping System Testing \& Balancing } \\
\text { D3072 Air Systems Testing \& Balancing } \\
\text { D3073 } \text { HVAC Commissioning } \\
\text { D3079 } \text { Other Systems Testing and Balancing }\end{array}$ \\
\hline $\begin{array}{l}\text { D3090 } \\
\text { Other HVAC } \\
\text { Systems \& } \\
\text { Equipment }\end{array}$ & $\begin{array}{l}\text { D3091 Special Cooling Systems \& Devices } \\
\text { D3092 Special Humidity Control } \\
\text { D3093 } \text { Dust \& Fume Collectors } \\
\text { D3094 Air Curtains } \\
\text { D3095 Air Purifiers } \\
\text { D3096 Paint Spray Booth Ventilation } \\
\text { D3097 General Construction Items (HVAC) }\end{array}$ \\
\hline $\begin{array}{l}\text { D4010 } \\
\text { Sprinklers }\end{array}$ & $\begin{array}{ll}\text { D4011 } & \text { Sprinkler Water Supply } \\
\text { D4012 } & \text { Sprinkler Pumping Equipment } \\
\text { D4013 } & \text { Dry Sprinkler System }\end{array}$ \\
\hline
\end{tabular}




\begin{tabular}{|c|c|}
\hline $\begin{array}{l}\text { D4020 } \\
\text { Standpipes }\end{array}$ & $\begin{array}{ll}\text { D4021 } & \text { Standpipe Water Supply } \\
\text { D4022 } & \text { Pumping Equipment } \\
\text { D4023 } & \text { Standpipe Equipment } \\
\text { D4024 } & \text { Fire Hose Equipment }\end{array}$ \\
\hline $\begin{array}{l}\text { D4030 } \\
\text { Fire Protection } \\
\text { Specialties }\end{array}$ & $\begin{array}{l}\text { D4031 Fire Extinguishers } \\
\text { D4032 Fire Extinguisher Cabinets }\end{array}$ \\
\hline $\begin{array}{l}\text { D4090 } \\
\text { Other Fire } \\
\text { Protection } \\
\text { Systems }\end{array}$ & $\begin{array}{l}\text { D4091 Carbon Dioxide Systems } \\
\text { D4092 Foam Generating Equipment } \\
\text { D4093 Clean Agent Systems } \\
\text { D4094 Dry Chemical System } \\
\text { D4095 Hood \& Duct Fire Protection }\end{array}$ \\
\hline $\begin{array}{l}\text { D5010 } \\
\text { Electrical Service } \\
\text { \& Distribution }\end{array}$ & $\begin{array}{l}\text { D5011 High Tension Service \& Dist. } \\
\text { D5012 Low Tension Service \& Dist. }\end{array}$ \\
\hline $\begin{array}{l}\text { D5020 } \\
\text { Lighting \& } \\
\text { Branch Wiring }\end{array}$ & $\begin{array}{l}\text { D5021 Branch Wiring Devices } \\
\text { D5022 Lighting Equipment }\end{array}$ \\
\hline $\begin{array}{l}\text { D5030 } \\
\text { Communications } \\
\text { \& Security }\end{array}$ & $\begin{array}{ll}\text { D5031 } & \text { Public Address \& Music Systems } \\
\text { D5032 } & \text { Intercommunication \& Paging } \\
& \text { System } \\
\text { D5033 } & \text { Telephone Systems } \\
\text { D5034 } & \text { Call Systems } \\
\text { D5035 } & \text { Television Systems } \\
\text { D5036 } & \text { Clock and Program Systems } \\
\text { D5037 } & \text { Fire Alarm Systems } \\
\text { D5038 } & \text { Security and Detection Systems } \\
\text { D5039 } & \text { Local Area Networks }\end{array}$ \\
\hline $\begin{array}{l}\text { D5090 } \\
\text { Other Electrical } \\
\text { System }\end{array}$ & $\begin{array}{ll}\text { D5091 } & \text { Grounding Systems } \\
\text { D5092 } & \text { Emergency Light \& Power Systems } \\
\text { D5093 } & \text { Floor Raceway Systems } \\
\text { D5094 } & \text { Other Special Systems \& Devices } \\
\text { D5095 } & \text { General Construction Items (Elect.) }\end{array}$ \\
\hline $\begin{array}{l}\text { E1010 } \\
\text { Commercial } \\
\text { Equipment }\end{array}$ & $\begin{array}{l}\text { E1011 } \text { Security \& Vault Equipment } \\
\text { E1012 Teller and Service Equipment } \\
\text { E1013 Registration Equipment } \\
\text { E1014 Checkroom Equipment } \\
\text { E1015 } \text { Mercantile Equipment } \\
\text { E1016 Laundry \& Dry Cleaning Equipment } \\
\text { E1017 Vending Equipment } \\
\text { E1018 Office Equipment }\end{array}$ \\
\hline $\begin{array}{l}\text { E1020 } \\
\text { Institutional } \\
\text { Equipment }\end{array}$ & $\begin{array}{ll}\text { E1021 } & \text { Ecclesiastical Equipment } \\
\text { E1022 } & \text { Library Equipment } \\
\text { E1023 } & \text { Theater \& Stage Equipment } \\
\text { E1024 } & \text { Instrumental Equipment } \\
\text { E1025 } & \text { Audio-visual Equipment } \\
\text { E1026 } & \text { Detention Equipment } \\
\text { E1027 } & \text { Laboratory Equipment } \\
\text { E1028 } & \text { Medical Equipment } \\
\text { E1029 } & \text { Other Institutional Equipment }\end{array}$ \\
\hline $\begin{array}{l}\text { E1030 } \\
\text { Vehicular } \\
\text { Equipment }\end{array}$ & $\begin{array}{ll}\text { E1031 Vehicular Service Equipment } \\
\text { E1032 Parking Control Equipment } \\
\text { E1033 Loading Dock Equipment } \\
\text { E1039 } & \text { Other Vehicular Equipment } \\
\end{array}$ \\
\hline $\begin{array}{l}\text { E1090 } \\
\text { Other Equipment }\end{array}$ & $\begin{array}{ll}\text { E1091 } & \text { Maintenance Equipment } \\
\text { E1092 Solid Waste Handling Equipment } \\
\text { E1093 Food Service Equipment } \\
\text { E1094 Residential Equipment } \\
\text { E1095 Unit Kitchens } \\
\text { E1097 Window Washing Equipment } \\
\text { E1099 } & \text { Other Equipment } \\
\end{array}$ \\
\hline
\end{tabular}

\begin{tabular}{|l|l|}
\hline E2010 & E2011 Fixed Artwork \\
E2012 Fixed Casework \\
E2013 Blinds and Other Window Treatment \\
E2014 Fixed Floor Grilles and Mats \\
E2015 Fixed Multiple Seating \\
E2016 Fixed Interior Landscaping
\end{tabular}




\section{Chart 5.2 Suggested Level 4 for the UNIFORMAT II Classification of Building- Related Sitework}

\begin{tabular}{|c|c|c|c|}
\hline Level 3 Elements & Level 4 Sub-Elements & Level 3 Elements & Level 4 Sub-Elements \\
\hline $\begin{array}{l}\text { G1010 } \\
\text { Site Clearing }\end{array}$ & $\begin{array}{l}\text { G1011 Clearing \& Grubbing } \\
\text { G1012 } \\
\text { Tree Removal \& } \\
\text { Thinning }\end{array}$ & $\begin{array}{l}\text { G3020 } \\
\text { Sanitary Sewer }\end{array}$ & $\begin{array}{ll}\text { G3021 } & \text { Piping } \\
\text { G3022 } & \text { Manholes \& Cleanouts } \\
\text { G3023 } & \text { Septic Disposal Systems } \\
\text { G3024 } & \text { Lift Stations } \\
\text { G3025 } & \text { Packaged Water Waste Treatment } \\
& \text { Plants } \\
\text { G3026 } & \text { Septic Tanks } \\
\text { G3027 } & \text { Drain Fields } \\
\end{array}$ \\
\hline $\begin{array}{l}\text { G1020 } \\
\text { Site Demolition \& } \\
\text { Relocation }\end{array}$ & $\begin{array}{ll}\text { G1021 } & \text { Building Demolition } \\
\text { G1022 } & \begin{array}{l}\text { Demolition of Site } \\
\text { Components }\end{array} \\
\text { G1023 } & \begin{array}{l}\text { Relocation of Building } \\
\text { \& Utilities }\end{array} \\
\text { G1024 } & \text { Utilities Relocation }\end{array}$ & $\begin{array}{l}\text { G3030 } \\
\text { Storm Sewer }\end{array}$ & $\begin{array}{l}\text { G3031 Piping } \\
\text { G3032 } \text { Manholes } \\
\text { G3033 } \text { Headwalls \& Catch Basins } \\
\text { G3034 Lift Stations } \\
\text { G3035 Retention Ponds } \\
\text { G3036 } \text { Ditches \& Culverts }\end{array}$ \\
\hline $\begin{array}{l}\text { G1030 } \\
\text { Site Earthwork }\end{array}$ & $\begin{array}{ll}\text { G1031 } & \text { Site Grading Excavation } \\
\text { G1032 } & \text { Borrow Fill } \\
\text { G1033 } & \text { Soil Stabilization \& Treatment } \\
\text { G1034 } & \text { Site Dewatering } \\
\text { G1035 } & \text { Site Shoring } \\
\text { G1036 } & \text { Embankments } \\
\text { G1037 Erosion Control } \\
\end{array}$ & $\begin{array}{l}\text { G3040 } \\
\text { Heating Distribution }\end{array}$ & $\begin{array}{l}\text { G3041 Steam Supply } \\
\text { G3042 Condensate Return } \\
\text { G3043 Hot Water Supply System } \\
\text { G3044 Pumping Stations }\end{array}$ \\
\hline $\begin{array}{l}\text { G1040 } \\
\text { Hazardous Waste } \\
\text { Remediation }\end{array}$ & $\begin{array}{ll}\text { G1041 } & \text { Removal of Contaminated Soil } \\
\text { G1042 } & \text { Soil Restoration \& } \\
& \text { Treatment }\end{array}$ & $\begin{array}{l}\text { G3050 } \\
\text { Cooling Distribution }\end{array}$ & $\begin{array}{l}\text { G3051 Chilled Water Piping } \\
\text { G3052 Wells for Cooling/Heating } \\
\text { G3053 Pumping Stations } \\
\text { G3054 Cooling Towers on Site }\end{array}$ \\
\hline $\begin{array}{l}\text { G2010 } \\
\text { Roadways }\end{array}$ & $\begin{array}{l}\text { G2011 Bases and Sub-Bases } \\
\text { G2012 Paving \& Surfacing } \\
\text { G2013 Curbs Gutters \& Drains } \\
\text { G2014 Guardrails and Barriers } \\
\text { G2015 Painted Lines } \\
\text { G2016 Markings \& Signage } \\
\text { G2017 Vehicular Bridges } \\
\end{array}$ & $\begin{array}{l}\text { G3060 } \\
\text { Fuel Distribution }\end{array}$ & $\begin{array}{l}\text { G3061 Fuel Piping } \\
\text { G3062 Fuel Equipment } \\
\text { G3063 Fuel Storage Tanks } \\
\text { G3064 Fuel Dispensing Stations }\end{array}$ \\
\hline $\begin{array}{l}\text { G2020 } \\
\text { Parking Lots }\end{array}$ & $\begin{array}{ll}\text { G2021 } & \text { Bases and Sub-Bases } \\
\text { G2022 Paving \& Surfacing } \\
\text { G2023 Curbs, Rails \& Barriers } \\
\text { G2024 Parking Booths \& Equipment } \\
\text { G2025 Markings \& Signage } \\
\end{array}$ & $\begin{array}{l}\text { G3090 } \\
\text { Other Site Mechanical } \\
\text { Utilities }\end{array}$ & $\begin{array}{l}\text { G3091 Industrial Waste Systems } \\
\text { G3092 POL (Petroleum Oil \& } \\
\text { Lubricants) Distribution Systems }\end{array}$ \\
\hline $\begin{array}{l}\text { G2030 } \\
\text { Pedestrian Paving }\end{array}$ & $\begin{array}{ll}\text { G2031 Paving \& Surfacing } \\
\text { G2032 Edging } \\
\text { G2033 Exterior Steps } \\
\text { G2034 Pedestrian Bridges }\end{array}$ & $\begin{array}{l}\text { G4010 } \\
\text { Electrical Distribution }\end{array}$ & $\begin{array}{ll}\text { G4011 } & \text { Substations } \\
\text { G4012 } & \text { Overhead Power Distribution } \\
\text { G4013 } & \text { Underground Power Distribution }\end{array}$ \\
\hline $\begin{array}{l}\text { G2040 } \\
\text { Site Development }\end{array}$ & $\begin{array}{ll}\text { G2041 } & \text { Fences \& Gates } \\
\text { G2042 } & \text { Retaining Walls } \\
\text { G2043 } & \text { Terrace \& Perimeter Walls } \\
\text { G2044 } & \text { Signage } \\
\text { G2045 } & \text { Site Furnishings } \\
\text { G2046 } & \text { Fountains, Pools, \& } \\
& \text { Watercourses } \\
\text { G2047 } & \text { Playing Fields } \\
\text { G2048 } & \text { Flagpoles } \\
\text { G2049 } & \text { Miscellaneous Structures } \\
\end{array}$ & $\begin{array}{l}\text { G4020 } \\
\text { Site Lighting }\end{array}$ & $\begin{array}{ll}\text { G4021 } & \text { Fixtures \& Transformers } \\
\text { G4022 } & \text { Poles } \\
\text { G4023 Wiring Conduits \& Ductbanks } \\
\text { G4024 Site Lighting Controls }\end{array}$ \\
\hline $\begin{array}{l}\text { G2050 } \\
\text { Landscaping }\end{array}$ & $\begin{array}{ll}\text { G2051 } & \text { Fine Grading \& Soil Preparation } \\
\text { G2052 } & \text { Erosion Control Measures } \\
\text { G2053 } & \text { Top Soil and Planting Beds } \\
\text { G2054 } & \text { Seeding and Sodding } \\
\text { G2055 Planting } \\
\text { G2056 Planters } \\
\text { G2057 } & \text { Irrigation Systems } \\
\text { G2059 } & \text { Other Landscape Features } \\
\end{array}$ & $\begin{array}{l}\text { G4030 } \\
\text { Site Communication \& } \\
\text { Security }\end{array}$ & $\begin{array}{ll}\text { G4031 Site Communications Systems } \\
\text { G4032 Site Security \& Alarm Systems }\end{array}$ \\
\hline \multirow[t]{3}{*}{$\begin{array}{l}\text { G3010 } \\
\text { Water Supply }\end{array}$} & \multirow[t]{3}{*}{$\begin{array}{l}\text { G3011 Potable Water Distribution } \\
\text { and Storage } \\
\text { G3012 } \\
\text { Non Potable Water Distrib. } \\
\text { and Storage } \\
\text { G3013 Well Systems } \\
\text { G3014 } \begin{array}{l}\text { Fire Protection Distribution } \\
\text { and Storage }\end{array} \\
\text { G3015 Pumping Stations } \\
\text { G3016 Package Water Treatment } \\
\text { Plants }\end{array}$} & $\begin{array}{l}\text { G4090 } \\
\text { Other Site Electrical } \\
\text { Utilities }\end{array}$ & $\begin{array}{l}\text { G4091 Cathodic Protection } \\
\text { G4092 Site Emergency Power Generation }\end{array}$ \\
\hline & & $\begin{array}{l}\text { G9010 } \\
\text { Service \& Pedestrian } \\
\text { Tunnels }\end{array}$ & $\begin{array}{ll}\text { G9011 } & \text { Service Tunnels } \\
\text { G9012 } & \text { Trench Boxes } \\
\text { G9013 } & \text { Pedestrian Tunnels } \\
\end{array}$ \\
\hline & & $\begin{array}{l}\text { G9090 } \\
\text { Other Site Systems }\end{array}$ & G9091 Snow Melting Systems \\
\hline
\end{tabular}


Improved Life-Cycle Costing-A Level-4 classification permits a more comprehensive level of building detail for assembling operation, maintenance, and repair costs in addition to initial construction costs. Having lower level costs early in the design process helps users select cost-effective sub-elements and whole building alternatives on a lifecycle cost basis.

Building Condition Assessment-Evaluating building conditions for Level-4 subelements as opposed to higher levels allows facility managers to track conditions at a level that corresponds to typical operation, maintenance, and repair activities. This facilitates reporting physical condition and estimating costs for correction, as well as preparing long-term capital replacement budgets.

Library of Technical Data-By classifying and filing technical and product data according to a Level-4 format, users will be able to find data more quickly.

Civil Works Sitework-The addition of 128 sub-elements in Level-4 sitework makes UNIFORMAT II feasible as a tool for organizing sitework on small and medium civil works projects, such as parks.

Detailed Checklist-A formal Level-4 definition can be used as a checklist for most UNIFORMAT II applications described in Sections 3 and 4. These include specifications, estimates, technical design reviews, and building condition assessment. A greater level of detail will enhance project control and improve cost effectiveness. 


\section{Summary and Suggestions for Further Work}

\subsection{Summary}

The building community needs a building classification framework to provide a consistent reference for the description, economic analysis, and management of buildings during all phases of their life cycle. This includes the planning, programming, design, construction, operations, and disposal phases. An elemental classification best satisfies this need because it facilitates economic analysis early in the design stage before adequate information has been developed to generate product-based estimates of project costs. Building elements are major components that are common to most buildings and that perform a given function regardless of the design specification, construction method, or materials. Building foundations, exterior walls, and lighting are examples of elements.

UNIFORMAT II is an elemental classification that has been standardized by ASTM and is being widely adopted. It is proposed in this report as the appropriate classification for use in every phase of the building process. Data entered in a consistent format will not have to be reentered at subsequent phases of the building life cycle. Users will understand and be able to compare information at every phase because it is linked via common, uniform, physical elements or activities - the standard elements of UNIFORMAT II. Better information, generated early in the construction process and at less cost, will help owners, builders, designers, facility managers, and occupants build and manage their building for lower life-cycle costs.

Chapter 2 presents the 1997 ASTM UNIFORMAT II classification in three hierarchical levels for both building elements and related sitework elements. The criteria for deciding in which part of the framework to locate each element is described in detail. Although this 3-level hierarchy has been successfully implemented, some Level-3 elements are sufficiently general that it is not always clear where to classify more finely detailed items. For this reason we introduce a fourth hierarchical level (presented in detail in Chapter 5). Having a fourth-level category will improve communication, enhance project control, and increase cost effectiveness in the building process.

Chapter 3 lists the many applications of UNIFORMAT II now in practice in all phases of the building life cycle. Selected applications in writing performance specifications, technical requirements, and preliminary project descriptions are described in detail. An example of a major benefit from using UNIFORMAT II in preliminary project descriptions at schematic design is that value engineering, life-cycle costing, and energy analysis can be initiated before the design development stage is initiated. This allows optimization when there is potential for significant cost savings-i.e., before the project design becomes locked in.

Chapter 4 treats elemental estimating, how it differs from product estimates, and the importance of design cost analysis parameters. An elemental estimate format incorporating cost analysis parameters is recommended to facilitate comparisons with 
targeted costs and those of similar projects in historical databases. The elemental estimate format is illustrated with cost estimates generated for an eight-story office building. Underlying estimate data sheets are also provided to help explain the derivation of the building's summary elemental costs. To facilitate using UNIFORMAT II, sources of elemental cost and engineering data are provided.

Chapter 5 presents a recommended fourth level of sub-elements for UNIFORMAT II. The Level-4 sub-elements provide numerous advantages over the current three levels of UNIFORMAT II. Improved cost data emerge, resulting in better cost estimates and an improved historical cost database. Most importantly, a Level-4 classification permits more comprehensive building details for assembling operation, maintenance, and repair costs as well as initial construction costs. This helps users better estimate life-cycle costs and thereby make life-cycle, cost-effective building selections early in the design process when the potential for cost savings is greatest. Finally, having Level-4 sub-elements allows facility managers to assess building conditions at a level that corresponds to typical operation, maintenance, and repair activities. This facilitates the reporting of building condition, the estimation of maintenance, repair, renovation, and retrofit costs, and the preparation of long-term capital replacement budgets.

\subsection{Suggestions for Further Work}

Five suggestions are proposed for further work. The first is to revise the ASTM UNIFORMAT II classification to incorporate the Level-4 sub-elements described in Chapter 5. This will require collaboration among users of the classification and writers of the standard to arrive at a consensus of enhancements that will better help UNIFORMAT II meet user needs. A Level-4 classification of sub-elements in buildingrelated sitework with 128 designations would produce a framework that could be applicable for small-to-medium-sized civil works projects such as parks, thus expanding significantly the user base for the standard.

The second suggestion is to develop counterpart formats to UNIFORMAT II for nonbuilding applications. Figure 6.1 shows potential industry users of UNIFORMAT II. The shaded building and site-related boxes indicate that a standard format exists for those applications. The dark-bordered box for bridges indicates that there is a "standard in process" on UNIFORMAT II for bridges. The other boxes represent potential areas for the development of specialized UNIFORMAT II standard formats. Note that the anticipated benefits of a UNIFORMAT II for bridges or any of these other applications are similar to what we described in this report for buildings.

The third suggestion is to develop standard elemental units of measurement and cost analysis parameters or factors for use in comparing cost estimates among similar projects and to a database of elemental costs. These units of measurement and cost analysis factors would be candidates for ASTM standards. 
Figure 6.1 Framework of the Built Environment

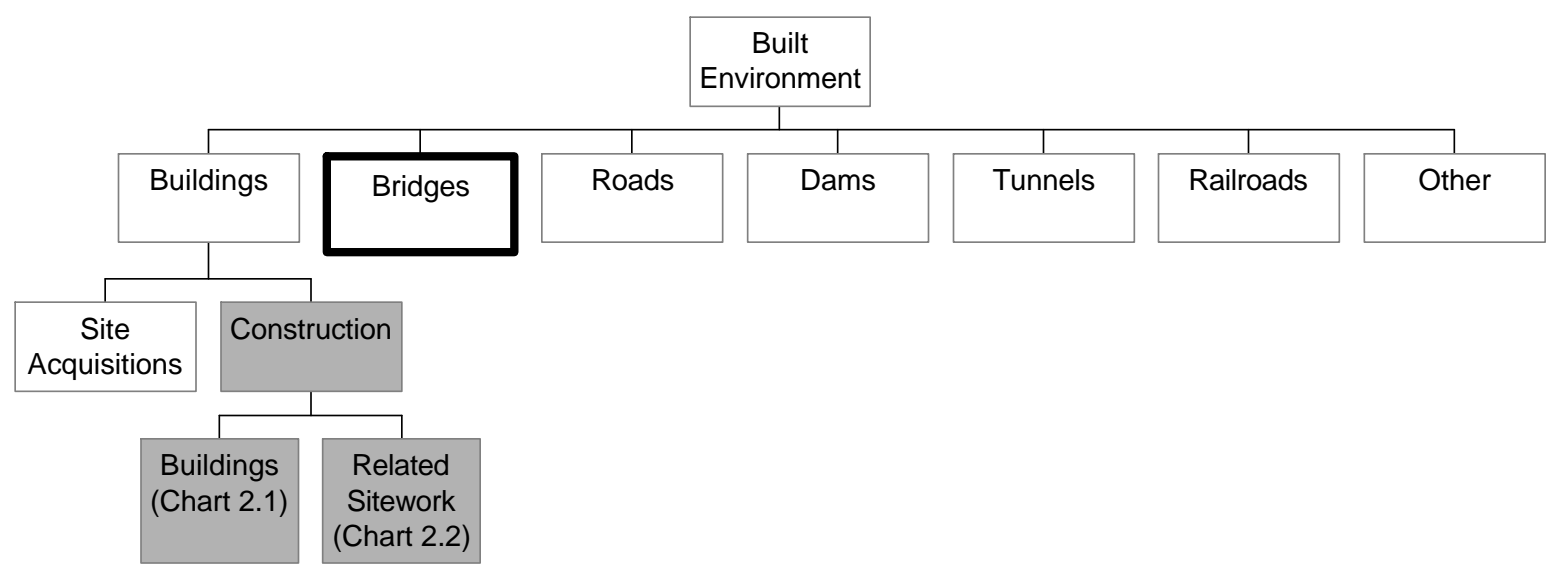

The fourth suggestion is to present to ASTM a standard summary format (based on Tables 4.3, 4.4, and 4.5) for presenting elemental cost estimates of buildings during design. Using the same UNIFORMAT II format consistently over time and over all projects will ensure that managers and other audiences of economic presentations will understand exactly what elements contain and what they are projected to cost. UNIFORMAT II becomes the thread that ties project information together through all phases of the building's life cycle.

The fifth suggestion is to use the UNIFORMAT II format to record information on the National Construction Goals (NCGs). The NCGs were formulated by a broad cross section of the construction industry to promote the competitiveness of the U.S.

Construction industry. The program provides baseline measures of industry practices and tools and information on ways to reduce construction cycle time, first costs, life-cycle costs, and injuries and illnesses. By providing a definitive and consistent format, UNIFORMAT II would promote performance improvement efforts through reference to information on industry norms (e.g., first costs for Levels 3 and 4) and the ability to identify and benchmark against industry leaders. 


\title{
APPENDIX A Author Profiles
}

\author{
ROBERT P. CHARETTE
}

Mr. Charette, a professional engineer, is an associate adjunct professor at Concordia University. He led the ASTM Building Economics Subcommittee in developing ASTM's UNIFORMAT II Standard Classification for Building Elements and Related Sitework. $\mathrm{He}$ is accredited as a Certified Value Specialist by the Society of American Value Engineers and qualified as a Professional Quantity Surveyor with the Canadian Institute of Quantity Surveyors. He was formerly National Director of the Value Engineering and Life-Cycle Costing Services for Hanscomb Consultants in Canada and the United States. Mr. Charette is a member of the Architectural Engineering Institute of the American Society of Civil Engineers, the Construction Specification Institute, the Design-Build Institute of America, and the Association for Project Managers. He has lectured and presented seminars on Value Engineering, Life-Cycle Costing, and UNIFORMAT II for Design Management at both the undergraduate and post graduate levels at McGill University's School of Architecture, Design and Modelling Centre; Schools of Architecture and Engineering at the University of Montreal; Ecole de Technolgie Superieure; Concordia University; Harvard Graduate School of Design; and the University of Wisconsin.

\section{HAROLD E. MARSHALL}

Dr. Marshall heads the Office of Applied Economics at the National Institute of Standards and Technology. His specialty is developing standard economic methods and risk analysis techniques for evaluating investment projects. Dr. Marshall is co-author of a book on building economics, and has published over 40 articles, chapters in books, and technical papers. He chairs for the American Society for Testing and Materials the Building Economics Subcommittee which has produced thirteen standard economic methods used worldwide for evaluating investments in buildings and construction. As advisory editor to the international journal Construction Management and Economics and to AACE International's Cost Engineering, he keeps abreast of developments at home and abroad in building economics. A graduate of the George Washington University (Ph.D. in 1969, M.A., 1965, and B.A., 1964), Dr. Marshall's early career included teaching economics for the George Washington University, George Mason University, and for two years on World Campus Afloat's around-the-world shipboard college. In recognition of his contributions in building economics, Dr. Marshall received in 1986 the American Association of Cost Engineers' highest honor, the Award of Merit, and in 1988 the American Society for Testing and Materials Award of Merit and accompanying honorary title of Fellow of the Society. 


\section{APPENDIX B UNIFORMAT II, Level-3 ELEMENT DESCRIPTIONS—List of Inclusions and Exclusions}

The following lists show what items are included and excluded at Level 3 in the 1997 version of the ASTM Standard Classification for Building Elements and Related Sitework. Note that the listings of inclusions and exclusions are not intended to be an exhaustive listing. Rather, they provide a general outline of what to expect in each element consistent with the selection criteria outlined in section 2.2. Exclusions are listed to help users find items quickly. For example, a user might place exterior load bearing walls under B2010 Exterior Walls or B1010 Floor Construction. UNIFORMAT II puts them under B2010 Exterior Walls based on technical judgment and current practice. Putting under B1010 Floor Construction a cross-reference to B2010 Exterior Walls directs the person who looks first under Floor Construction to the appropriate element, Exterior Walls.

\section{B.1 Description of Building Elements}

\section{A 10 Foundations}

\section{A $1010 \quad$ Standard Foundations}

\section{$\underline{\text { Includes }}$}

- wall \& column foundations

- foundation walls up to level of top of slab on grade

- pile caps

- backfill \& compaction

- footings \& bases

- perimeter insulation

- perimeter drainage

- anchor plates

- dewatering

\section{$\underline{\text { Excludes }}$}

- general excavation to reduce levels (see section G 1030, Site Earthwork)

- excavation for basements (see section A 2010, Basement Excavation)

- basement walls (see section A 2020, Basement Walls)

- under-slab drainage and insulation (see section A 1030, Slab on Grade)

\section{A 1020 Special Foundations}

\section{Includes}

- piling

- caissons

- underpinning

- dewatering

- raft foundations

\section{$\underline{\text { Excludes }}$}

- pile caps (see section A 1010, Standard Foundations)

- rock excavation (unless associated with Special Foundations) (see section A 1010, Standard Foundations \& section A 2010, 
- grade beams

- any other special foundation conditions
Basement Excavation)

\section{A 1030 Slab on Grade}

Includes

\section{Excludes}

- applied floor finishes (see section C 3020, Floor Finishes)

- standard

- structural

- inclined slabs on grade

- trenches

- hardeners \& sealers to the slab (see section C 3020, Floor Finishes)

- pits

- bases

- under-slab drainage

- under-slab insulation

\section{A 20 Basement Construction}

\section{A 2010 Basement Excavation}

\section{Includes}

- additional excavation required for construction of basement

- backfill \& compaction

- excavation support system

\section{A 2020 Basement Walls}

\section{Includes}

- basement wall construction

- moisture protection

\section{$\underline{\text { Excludes }}$}

- walls above grade that enclose basements (see section B 2010, Exterior Walls)

- perimeter drainage (see section A 1010, Standard Foundations)

\section{B 10 Superstructure}

\section{B 1010 Floor Construction}

\section{$\underline{\text { Includes }}$}

- floor structural frame

- interior structural walls
- general grading to reduce levels over site (see section G 1030, Site Earthwork) 
- floor slabs \& decks

- inclined \& stepped floors

- expansion \& contraction joints

- balcony construction

- suspended ramps

- exterior stairs and fire escapes

- other floor construction (e.g., catwalks, space frames, etc.)
- applied \& suspended ceiling \& floor finishes (see section C 3020, Floor Finishes \& section C 3030, Ceiling Finishes)

- stair construction (see section C 2010, Stair Construction)

- balcony walls \& railings (see section B 2010, Exterior Walls)

\section{B 1020 Roof Construction}

\section{$\underline{\text { Includes }}$}

- roof structural frame

- structural interior walls supporting roof

- roof decks, slabs \& sheathing

- canopies

- other roof construction

\section{$\underline{\text { Excludes }}$}

- roof coverings (see section B 3010, Roof Coverings)

- $\quad$ skylights \& roof openings (see section B 3020 Openings)

- stair construction (see section C 2010, Stair Construction)

\section{B 20 Enclosure}

\section{B 2010 Exterior Walls}

\section{Includes}

- exterior wall construction with facing materials, exterior applied finishes,

- back-up construction, framing, wallboard, parapets, insulation \& vapor retarders, sheathing, wallboard

- exterior load-bearing wall construction

- exterior louvers \& screens

- exterior sun control devices

- balcony walls \& railings

- exterior soffits

\section{$\underline{\text { Excludes }}$}

- applied finishes to interior faces of exterior walls (see section C 3010, Wall Finishes)

- columns and beams in exterior walls (see section B 10, Superstructure)

- venetian blinds (see section E 20, Furnishings)

- other interior sun control devices (see section E 20, Furnishings)

- roof eaves and eaves soffits (see section B 3010, Roof Coverings)

- glazed curtain walls (see section B 2020, Windows) 


\section{B 2020 Exterior Windows}

Includes

- windows

- storefronts

- curtain walls

- exterior painting of windows

- wall opening elements such as lintels, sills, flashings, etc.

\section{Excludes}

- window treatments (see section E 20, Furnishings)

\section{B 2030 Exterior Doors}

\section{Includes}

- personnel doors

- revolving doors

- overhead doors

- other doors (e.g., hanger doors, blastresistant doors, etc.)

\section{B 30 Roofing}

\section{B 3010 Roof Coverings}

\section{Includes}

\section{$\underline{\text { Excludes }}$}

- roofing membranes

- traffic coatings

- waterproof membranes below paving

- expansion joints

- $\quad$ vapor retarder ${ }^{1}$

- roof \& deck insulation

- roof fill

- flashings \& trim

- gutters \& downspouts

- eaves \& eaves soffits
- roof openings (see section B 3020, Roof Openings)

- roof drains (see section D 2040, Rain Water Drainage)

- parapets (see section B 2010, Exterior Walls)

\footnotetext{
${ }^{1}$ A vapor retarder was formerly referred to as a vapor barrier.
} 


\section{B 3020 Roof Openings}

\section{Includes}

- skylights

- area glazing

- roof hatches

- gravity roof ventilators

- smoke vents

\section{Excludes}

- powered \& ducted ventilators (see section D 3040, Distribution Systems)

\section{10 Interior Construction}

\section{1010 Partitions}

\section{Includes}

- fixed partitions

- demountable partitions

- retractable \& movable partitions

- operable partitions

- interior balustrades \& screens

- interior window \& storefronts

- Though not in standard, C1010 includes field constructed toilet partitions

\section{$\underline{\text { Excludes }}$}

- stair balustrades (see section C 2010, Stair Construction)

- interior load bearing \& shear walls (see section B 10, Superstructure)

- applied wall finishes (see section C 3010, Wall Finishes)

- Fabricated toilet partitions ( see section C1030, Fittings)

\section{1020 Interior Doors}

\section{Includes}

- standard swinging doors

- glazed doors

- sliding \& folding doors

- fire doors

- other doors

- door frames

- door hardware

- door opening elements

- door painting \& staining

- hatches \& access doors

\section{Excludes}

- vault doors (see section E 10, Equipment)

- operable partitions (see section C 1010, Partitions) 


\section{1030 Fittings}

Includes

- chalk \& tack boards

- identifying devices

- lockers

- toilet \& bath accessories

- storage shelving

- handrails \& ornamental metals

- fabricated toilet partitions

- fabricated compartments and cubicles

- closet specialties

\section{$\underline{\text { Excludes }}$}

- $\quad$ equipment (see section E 10, Equipment)

- furniture (see section E 20, Furnishings)

- special construction (see section F 10, Special Construction)

- fire extinguishers (see section D 4030, Fire Protection Specialties)

- manufactured case work (see section E 20, Furnishings)

\section{20 Stairs}

\section{2010 Stair Construction}

\section{Includes}

- $\quad$ stair treads, risers and landings

- handrails and balustrades

\section{$\underline{\text { Excludes }}$}

steps in structural slabs (see section B 1010, Floor Construction)

\section{2020 Stair Finishes}

\section{Includes}

- finishes to treads, risers, landings \& soffits

- finishes to handrails \& balustrades

\section{30 Interior Finishes}

\section{3010 Wall Finishes}

\section{Includes}

- concrete wall finishes

- wall plastering

- wallboard

- tile \& terrazzo

- painting

- wallcoverings

- acoustic wall treatment

- other coatings \& finishings

\section{Excludes}

- wallboard integral to interior walls \& partitions (see section C 1010, Partitions, B2010, Exterior walls) 


\section{3020 Floor Finishes}

\section{$\underline{\text { Includes }}$}

- floor toppings and traffic membranes

- hardeners \& sealers

- tile, terrazzo, wood \& resilient flooring

- carpeting

- masonry \& stone flooring

- other flooring (e.g., conductive, armored)

- painting \& staining

- access pedestal flooring

\section{$\underline{\text { Excludes }}$}

- $\quad$ stair finishes (see section C 2020, Stair Finishes)

\section{3030 Ceiling Finishes}

\section{Includes}

- exposed concrete finishes

- plaster ceiling finishes

- wallboard ceiling finishes

- acoustic ceiling tiles \& panels

- painting \& staining

- metal strip ceilings

- other ceilings

- all suspended systems

\section{$\underline{\text { Excludes }}$}

- finishes to stair soffits (see section C 2020, Stair Finishes)

- finishes to exterior soffits (see section B 2010, Exterior Walls)

\section{10 Conveying}

\section{1010 Elevators and Lifts}

\section{Includes}

- passenger elevators

- freight elevators

- people lifts

- wheel chair lifts

\section{$\underline{\text { Excludes }}$}

- elevator pits (see section A 1030, Slab on Grade)

\section{1020 Escalators and Moving Walks}

\section{Includes}

- escalators

- moving walks 


\section{1090 Other Conveying Systems}

\section{Includes}

- hoist \& cranes

- conveyors

- dumbwaiters

- pneumatic tube systems

- linen, trash \& mail chutes

- turntables

- operable scaffolding

- transportation systems (for example baggage handling and aircraft loading systems)

\section{20 Plumbing}

\section{2010 Plumbing Fixtures}

\section{Includes}

- water closets

- urinals

- lavatories

- sinks

- showers

- bathtubs

- drinking fountains

- bidets

\section{$\underline{\text { Excludes }}$}

- domestic hot water heaters (see section D 2020, Domestic Water)

- hose bibbs (see section D 2020, Domestic Water)

- other equipment (see section D 2090, Other Plumbing Systems)

\section{2020 Domestic Water Distribution}

\section{Includes}

- $\quad$ pipes \& fittings

- $\quad$ valves, hydrants \& hose bibbs

- water heaters

- domestic water supply equipment

- insulation

\section{Excludes}

- plumbing fixtures (see section D 2010, Plumbing Fixtures) 


\section{2030 Sanitary Waste}

\section{Includes}

- waste pipe \& fittings

- vent pipe \& fittings

- floor drains

- sanitary waste equipment

- insulation

\section{2040 Rain Water Drainage}

\section{Includes}

- pipe \& fittings

- roof drains

- insulation

\section{$\underline{\text { Excludes }}$}

- gutters \& downspouts (see section B 3010, Roof Coverings)

\section{2090 Other Plumbing Systems}

\section{Includes}

- other piping systems

- gas distribution

- acid waste systems

- pool equipment

- fountain piping systems \& devices

\section{30 HVAC}

\section{3010 Energy Supply}

\section{Includes}

- oil, gas, \& coal supply

- $\quad$ steam, hot \& chilled water supply

- solar energy supply

- wind energy supply

\section{Excludes}

- electrical energy supply systems (see section D 5090, Other Electrical Systems, and section D 5010, Service \& Distribution) 


\section{3020 Heat Generating Systems}

Includes

- boilers, including electric

- piping and fittings adjacent to boilers

- primary pumps

- auxiliary equipment

- equipment \& piping insulation

\section{Excludes}

- electric space unit heaters \& baseboard, fuel fired unit heaters, furnaces (see section D 3050, Terminal \& Package Units)

controls \& instrumentation (see section D 3060, Controls \& Instrumentation)

\section{3030 Cooling Generating Systems}

\section{Includes}

- chillers

- cooling towers \& evaporative coolers

- condensing units

- piping \& fittings

- primary pumps

- direct expansion systems

- equipment \& piping insulation

\section{Excludes}

- secondary chilled water pumps (see section D 3040, Distribution Systems)

- distribution piping (see section D 3040, Distribution Systems)

- controls \& instrumentation (see section D 3060, Controls \& Instrumentation)

\section{3040 Distribution Systems}

\section{Includes}

- supply \& return air systems, including air handling units with coils (electric included), filters, ductwork, \& associated devices such as VAV boxes, duct heaters, induction units \& grilles

- ventilation \& exhaust systems

- steam, hot water, glycol \& chilled water distribution

- associated terminal devices including convectors, fan-coil units, \& induction units, but not water $\&$ steam unit heaters

- heat recovery equipment

- auxiliary equipment such as secondary pumps, heat exchangers, sound attenuation, \& vibration isolation

- piping, duct, \& equipment insulation

\section{Excludes}

- electric, gas, or oil fired unit heaters (see section D 3050, Terminal \& Package Units)

- furnaces (gas or oil) (see section D 3050, Terminal \& Package Units)

- floor, ceiling, \& rooftop package units (see section D 3050, Terminal \& Package Units)

- controls \& instrumentation (see section D 3060 , Controls \& Instrumentation) 


\section{3050 Terminal and Package Units}

Includes

- electric baseboard

- electric or fossil fuel fired unit heaters, unit ventilators, \& radiant heaters

- window or through-the-wall air conditioners, with or without heating of any type

- reverse-cycle, water- or air-cooled, terminal heat pumps

- wall sleeves where required

- electric or fossil fuel fired air-handling units or furnaces

- self-contained, air- or water-cooled, floor, ceiling, \& rooftop air conditioners, \& heat pumps

- ductwork and accessories, including flue stacks

- factory-integrated controls

\section{Excludes}

- $\quad$ piping \& accessories (see section D 3040, Distribution Systems)

- hydronic or steam convectors, fan-coil units (see section D 3040, Distribution Systems)

- cooling towers, remote air-cooled condensers, evaporative coolers (see section D 3030, Cooling Generation Systems)

- air-handling units with only hydronic heating or steam coils (see section D 3040, Distribution Systems)

- air-handling units with chilled water or direct expansion cooling coils (see section D 3040, Distribution Systems)

\section{3060 Controls and Instrumentation}

\section{Includes}

- heating generating systems

- cooling generating systems

- heating/cooling air handling units

- exhaust \& ventilating systems

- terminal devices

- energy monitoring \& control

- building automation systems

\section{$\underline{\text { Excludes }}$}

- factory-installed controls, when an integral part of terminal \& package units (see section D 3050, Terminal \& Package Units)

\section{3070 Systems Testing and Balancing}

\section{Includes}

- $\quad$ piping systems testing \& balancing

- air systems testing \& balancing 


\section{D3090 Other HVAC Systems and Equipment}

\section{Includes}

- special cooling systems and devices

- special humidity control

- dust and fume collectors

- air curtains

- air purifiers

- paint spray booth ventilation systems

- general construction items associated with mechanical systems

\section{40 Fire Protection}

\section{4010 Sprinklers}

\section{Includes}

- water supply equipment

- $\quad$ piping valves \& fittings

- sprinkler heads \& release devices

\section{4020 Standpipes}

\section{Includes}

- water supply equipment

- $\quad$ piping valves \& fittings

- cabinets \& hoses

\section{4030 Fire Protection Specialties}

\section{Includes}

- fire extinguishers

- fire extinguisher cabinets 


\section{4090 Other Fire Protection Systems}

\section{$\underline{\text { Includes }}$}

- carbon dioxide systems

- clean agent systems

- foam generating systems

- dry chemical systems

- exhaust hood systems

\section{50 Electrical}

\section{5010 Electrical Service and Distribution}

Includes

- primary transformers

- secondary transformers

- main switchboard

- interior distribution transformers

- branch circuit panels

- enclosed circuit breakers

- motor control centers

- conduit and wiring to circuit panels

\section{$\underline{\text { Excludes }}$}

- outdoor transformers (see section G 4010, Electrical Distribution)

- emergency power (see section D 5090, Other Electrical Systems)

- branch wiring (see section D 5020, Lighting \& Branch Wiring)

\section{5020 Lighting and Branch Wiring}

Includes

- branch wiring \& devices for lighting fixtures

- lighting fixtures

- branch wiring for devices \& equipment connections

- devices

- exterior building lighting

\section{$\underline{\text { Excludes }}$}

- underfloor raceways (see section D 5090, Other Electrical Systems)

- exterior site lighting (see section G 4020, Site Lighting)

\section{5030 Communications and Security}

\section{Includes}

- fire alarm systems

\section{$\underline{\text { Excludes }}$}

- other electrical systems (see section D 5090, Other Electrical Systems) 
- call systems

- telephone systems

- local area networks

- public address \& music systems

- intercommunication systems \& paging

- clock \& program systems

- television systems

- security systems

\section{5090 Other Electrical Systems}

\section{Includes}

- emergency generators

- UPS

- emergency lighting systems

- power factor correction

- lightning \& grounding protection systems

- raceway systems

- power generation systems

\section{Excludes}

- electric baseboard (see section D 3050, Terminal \& Package Units)

- electric coils \& duct heaters (see section D 3040, Distribution Systems)

- building automation \& energy monitoring systems (see section D 3060, Controls \& Instrumentation)

- communications \& security systems (see section D 5030, Communications \& Security)

\section{E 10 Equipment}

\section{E 1010 Commercial Equipment}

\section{Includes}

- security and vault equipment

- teller and service equipment

- registration equipment

- checkroom equipment

- mercantile equipment

- commercial laundry and dry cleaning equipment

- vending equipment

- office equipment 


\section{E 1020 Institutional Equipment}

\section{Includes}

- ecclesiastical equipment

- library equipment

- theater and stage equipment

- instrumental equipment

- audio-visual equipment

- detention equipment

- laboratory equipment

- medical equipment

- mortuary equipment

\section{E 1030 Vehicular Equipment}

\section{Includes}

- vehicular service equipment

- parking control equipment

- loading dock equipment

\section{E 1090 Other Equipment}

\section{Includes}

- maintenance equipment

- solid waste handling equipment

- food service equipment

- residential equipment

- unit kitchens

- darkroom equipment

- athletic, recreational, and therapeutic equipment

- planetarium equipment

- observatory equipment

- agricultural equipment 


\section{E 20 Furnishings}

\section{E 2010 Fixed Furnishings}

\section{Includes}

- fixed artwork

- fixed casework

- window treatment

- fixed floor grilles and mats

- fixed multiple seating

- fixed interior landscaping

\section{E 2020 Movable Furnishings}

\section{Includes}

- movable artwork

- furniture and accessories

- movable rugs and mats

- movable multiple seating

- movable interior landscaping

\section{F 10 Special Construction}

\section{F 1010 Special Structures}

\section{$\underline{\text { Includes }}$}

- air-supported structures

- pre-engineered structures

- other special structures

\section{$\underline{\text { Excludes }}$}

- solar \& wind energy supply (see section D 3010, Energy Supply)

\section{F 1020 Integrated Construction}

\section{Includes}

- integrated assemblies

- special purpose rooms

- other integrated construction 


\section{F 1030 Special Construction Systems}

\section{Includes}

- sound, vibration, and seismic construction

- radiation protection

- special security systems

- other special construction systems

\section{F 1040 Special facilities}

\section{Includes}

- aquatic facilities

- ice rinks

- site constructed incinerators

- kennels and animal shelters

- liquid and gas storage tanks

- other special facilities

\section{F 1050 Special Controls and Instrumentation}

\section{Includes}

- recording instrumentation

- building automation systems

- other special controls and instrumentation

\section{F 20 Selective Building Demolition}

\section{F 2010 Building Elements Demolition}

\section{Includes}

- demolition of existing building components

\section{Excludes}

- site demolition (see section G 1020, Site Demolition \& Relocations)

\section{F 2020 Hazardous Components Abatement}

\section{Includes}

- removal or encapsulation of hazardous building materials \& components 


\section{B.2 Description of Building-Related Sitework}

The following lists show what items are included and excluded in the sitework classification at Level 3. Note again that the numbers are for the purpose of organizing the report and are not classification numbers for the elements.

\section{G 10 Site Preparation}

\section{G 1010 Site Clearing}

\section{Includes}

- clearing \& grubbing

- tree removal \& thinning

\section{G 1020 Site Demolition and Relocations}

Includes

- complete building demolition

- demolition of site components

- relocation of buildings \& utilities $\underline{\text { Excludes }}$

- selective demolition within building (see section F 20, Selective Building Demolition)

\section{G 1030 Site Earthwork}

\section{Includes}

- grading, excavating \& fill to modify site contours

- $\quad$ soil stabilization \& treatment

- site watering

- site shoring

- embankments

\section{G 1040 Hazardous Waste Remediation}

\section{Includes}

- removal \& restoration of contaminated soil

\section{Excludes}

- building excavation for foundations and basements (see section A 10, Foundations \& section A 20, Basement Construction) 


\section{G 20 Site Improvement}

\section{G 2010 Roadways}

\section{Includes}

- paving sub-base

- paving \& surfacing

- curbs \& gutters

- rails \& barriers

- painted lines

- markings \& signage

\section{G 2020 Parking Lots}

\section{$\underline{\text { Includes }}$}

parking lot paving \& surfacing

- curbs, rails \& barriers

- parking booths \& equipment

- markings \& signage

\section{G 2030 Pedestrian Paving}

\section{Includes}

- paving \& surfacing

- exterior steps

\section{Excludes}

- waterproof membranes under terrace \& plaza paving (see section G 3010, Roof Coverings)

\section{G 2040 Site Development}

\section{Includes}

- fences \& gates

- retaining walls

- terrace \& perimeter walls

- signs

- site furnishings

- fountains, pools, \& watercourses

- playing fields

- flagpoles

- miscellaneous structures

- site equipment (for example car wash, banking system and theatre equipment located on the site)

\section{Excludes}

- $\quad$ signs (see section G 2010, Roadways \& section G 2020, Parking Lots) 


\section{G 2050 Landscaping}

\section{Includes}

\section{$\underline{\text { Excludes }}$}

- fine grading \& soil preparation

- top soil \& planting beds

- seeding \& sodding

- planting

- planters

- other landscape features

- irrigation systems

\section{G 30 Site Mechanical Utilities}

\section{G 3010 Water Supply}

\section{Includes}

- $\quad$ potable \& non-potable water systems

- well systems

- fire protection systems

- pumping stations

- water storage

\section{G 3020 Sanitary Sewer}

\section{Includes}

- piping

- manholes

- septic tanks

- lift stations

- package waste water treatment plants
- interior planters \& planting (see section E 20, Furnishings)

- site grading (see section G 1030, Site Earthwork) 


\section{G 3030 Storm Sewer}

\section{Includes}

- piping

- manholes

- catch basins

- lift stations

- retention ponds

- ditches \& culverts

\section{G 3040 Heating Distribution}

\section{Includes}

- steam supply

- condensate return

- hot water supply systems

\section{$\underline{\text { Excludes }}$}

- Service tunnels (see section G 9090, Service and Pedestrian Tunnels)

\section{G 3050 Cooling Distribution}

Includes

- chilled water piping

- wells for cooling

- pumping stations

- cooling towers on site

\section{G 3060 Fuel Distribution}

\section{Includes}

- piping

- equipment

- $\quad$ storage tanks

\section{G3090 Other Site Mechanical Utilities}

\section{Includes}

- industrial waste systems

- POL (Petroleum Oil \& Lubricants) distribution systems

\section{Excludes}

- service tunnels (see section G 9090, Service and Pedestrian Tunnels) 


\section{G 40 Site Electrical Utilities}

\section{G 4010 Electrical Distribution}

\section{Includes}

- substations

- overhead power distribution

- underground power distribution

- ductbanks

- grounding

\section{G 4020 Site Lighting}

\section{Includes}

- fixtures \& transformers

- poles

- wiring conduits \& ductbanks

- controls

- grounding

\section{G 4030 Site Communications and Security}

\section{Includes}

- overhead \& underground communications

- site security \& alarm systems

- ductbanks

- grounding

\section{G 4040 Other Site Electrical Utilities}

\section{Includes}

- cathodic protection

- emergency power generation 


\section{G 90 Other Site Construction}

G 9010 Service and Pedestrian Tunnels

\section{Includes}

- constructed service and pedestrian tunnels

- $\quad$ prefabricated service tunnels \& trench boxes

\section{G 9090 Other Site Systems}

\section{Includes}

- snow melting systems 


\section{APPENDIX C CSI MasterFormat $95^{\mathrm{TM}}$ Titles for Divisions 1-16}

1. GENERAL REQUIREMENTS

2. SITE CONSTRUCTION

3. CONCRETE

4. MASONRY

5. METALS

6. WOOD AND PLASTICS

7. THERMAL AND MOISTURE PROTECTION

8. DOORS AND WINDOWS

9. FINISHES

10. SPECIALTIES

11. EQUIPMENT

12. FURNISHINGS

13. SPECIAL CONSTRUCTION

14. CONVEYING SYSTEMS

15. MECHANICAL

16. ELECTRICAL 


\section{APPENDIX D Abbreviations and Symbols}

\begin{tabular}{ll} 
BCC & Building construction cost \\
BTC & Building trade cost \\
BTU & British thermal unit \\
CAB & Cabinet \\
CFM & Cubic feet per minute \\
CI & Cast iron \\
CY & Cubic yards \\
EA & Each \\
FIX & Fixtures \\
FLT & Flight \\
FPA & Footprint area \\
GFA & Gross floor area \\
HDS & Heads \\
HP & Horsepower \\
HR & Hour \\
KIP & Unit of weight equal to 1000 pounds \\
kW & Kilowatt \\
LB & Pounds \\
LF & Lineal feet \\
Lot & Lot \\
LVS & Leaves \\
MBH & Thousand BTU per hour \\
NPT & National pipe thread \\
NSA & Net site area \\
PR & Pair \\
PSF & Pounds per square foot load \\
SCC & Sitework construction cost \\
SF & Square feet \\
STC & Sitework trade cost \\
STOP & Stop for elevator \\
TCC & Total construction cost \\
TR & Tons of refrigeration \\
TSA & Total site area \\
VAV & Variable air volume \\
VLF & Vertical lineal feet \\
1 & Inches \\
& Feet \\
\hline &
\end{tabular}




\section{APPENDIX E References}

Ahuja, N. Hira, and Campbell, Walter J. Estimating from Concept to Completion (Englewood Cliffs, NJ: Prentice-Hall, Inc., 1988).

American Institute of Architects. "Chapter B5-Design and Construction Cost Management," Architect's Handbook of Professional Practice (Washington, DC: American Institute of Architects, 1984).

American Institute of Architects. MASTERCOST Instruction Manual (Washington, DC: American Institute of Architects, 1974).

American Institute of Architects. AIA Document D101- The Architectural Area and Volume of Buildings (Washington, DC: The American Institute of Architects, 1980).

American Institute of Architects. The Architect's Handbook of Professional Practice 7th Edition (Washington, DC: American Institute of Architects, 1992).

American Society for Testing and Materials. ASTM E 1496-98, "Standard Practice for Measuring Cost Risk of Buildings and Building Systems" (West Conshohocken, PA: American Society for Testing and Materials, 1998).

American Society for Testing and Materials. ASTM E 1557-97, "Standard Classification for Building Elements and Related Sitework- UNIFORMAT II" (West Conshohocken, PA: American Society for Testing and Materials, 1997).

Bowen, Brian and Robert P. Charette. "Elemental Cost Classification Standard for Building Design," 1991 American Association of Cost Engineers (AACE) Transactions (Seattle, WA: American Association of Cost Engineers, 1991).

Bowen, Brian, Robert Charette, and Harold Marshall. UNIFORMAT II - A Recommended Classification for Building Elements and Related Sitework, Special Publication 841 (Gaithersburg, MD: National Institute of Standards and Technology, 1992).

Canadian Institute of Quantity Surveyors. Elemental Cost Analysis-Method of Measurement and Pricing (Toronto, Ontario, Canada: Canadian Institute of Quantity Surveyors, first issued 1972, revised 1990).

Charette, Robert P. "New Design Management Tools for Projects Managers," The Association for Project Managers (APM) Journal, Volume 5, Issue 3, May 1998. Available on the APM website, www.construction.st/ UNIFORMAT.htm. 
Construction Specifications Institute. Practice FF/180. "Preliminary Project Description and Outline Specifications," Manual of Practice (Alexandria, VA: The Construction Specifications Institute, 1996).

Construction Specifications Institute. MasterFormat 95 Construction Specifications Institute, 1995 edition).

Construction Specifications Institute. UniFormat ${ }^{\mathrm{TM}}$ : A Uniform Classification of Construction Systems and Assemblies (Alexandria, VA: The Construction Specifications Institute, 1998 Edition).

Construction Specifications Institute and Design Build Institute of America. PerSpective ${ }^{\text {TM }}$, The Performance System for Project Teams (Alexandria, VA: Construction Specifications Institute; Washington, DC: Design-Build Institute of America, 1993). Web site—www.perspective.net.com.

Cox, B.J. and Horsley, William. Square Foot Estimating Methods, $2{ }^{\text {nd }}$ Edition (Kingston, MA: R.S. Means Co., Inc., 1995).

Dell'Isola, A.J and Kirk, S.J. Life Cycle Costing for Design Professionals, $2^{\text {nd }}$ Edition, (New York, NY: McGraw-Hill, Inc., 1995).

Dell'Isola, Michael. "Value Engineering Applications Using UNIFORMAT II," Proceedings of the Society of American Value Engineers (Atlanta, GA, 1998, pp. 7282.)

Delta Research Corporation. TRACES Generic Work Breakdown Structure, (Washington, DC: Tri Services WBS Subcommittee, 1992).

General Services Administration, Handbook PBS P 3440.5, Project Estimating Requirements (Washington, DC: General Services Administration, August 24, 1981).

Hanscomb Associates, Inc. Automated Cost Control \& Estimating System (Washington, DC: General Services Administration, 1975.)

International Organization for Standardization, ISO 9001, "Standard Model for Quality Assurance in Design, Development, Production, Installation, and Servicing," Element 4.9-Process Control (Geneva, Switzerland: International Organization for Standardization).

Killingsworth, Roger. Cost Control in Building Design (Kingston, MA: R.S. Means Co. Inc., 1988). 
Marshall, Harold E. and Ruegg, Rosalie T. Recommended Practice for Measuring Benefit/Cost and Savings-to-Investment Ratios for Buildings and Building Systems, Interagency Report 81-2397 (Gaithersburg, MD: National Institute of Standards and Technology, November 1981).

Marshall, Harold E. Recommended Practice for Measuring Net Benefits and Internal Rates of Return for Investments in Buildings and Building Systems, Interagency Report 83-2657 (Gaithersburg, MD: National Institute of Standards and Technology, October 1983).

Marshall, Harold E. Recommended Practice for Measuring Simple and Discounted Payback for Investments in Building and Building Systems, Interagency Report 842850 (Gaithersburg, MD: National Institute of Standards and Technology, March 1984).

Marshall, Harold E. Techniques for Treating Uncertainty and Risk in the Economic Evaluation of Building Investments, Special Publication 757 (Gaithersburg,MD: National Institute of Standards and Technology, September 1988).

Martin, J. and Rumble, P. An Elemental Approach to Design and Build Contracts (Berkshire, England: The Chartered Institute of Buildings, Construction Papers No. 79, 1997).

McGraw Hill. Time Saver Standards for Architectural Design, $7^{\text {th }}$ Edition (McGraw Hill, 1997).

National Institute of Building Sciences. Construction Criteria Database (Washington, DC: National Institute of Building Sciences).

Nisbet, James. Called to Account-Quantity Surveying 1936-1986 (London, England: Stokes Publications, 1989).

Parker, Donald E. and Dell' Isola, Alphonse J. Project Budgeting for Buildings (New York, NY: Van Nostrand Reinhold, 1991).

The Royal Architectural Institute of Canada. "Cost Planning and Cost Control Techniques," Volume 3, Canadian Handbook of Practice for Architects, $1^{\text {st }}$ Edition (Ottawa, Ontario, Canada: The Royal Architectural Institute of Canada, 1978).

Royal Institution of Chartered Surveyors (RICS) - Building Cost Information Service Ltd. (BCIS). Elements for Design and Build (London, England: The Royal Institution of Chartered Surveyors, 1996).

Royal Institution of Chartered Surveyors. Standard Form of Cost Analysis (London, England: The Building Cost Information Service, 1969 (Reprinted December 1987)). 
R.S. Means Co., Inc. Hanscomb's 1999 Yardsticks for Costing (Kingston, MA: R.S. Means Co., Inc., 1999).

R.S. Means Co., Inc. Means Assemblies Cost Data, $24^{\text {th }}$ Annual Edition (Kingston, MA: R.S. Means Co., Inc., 1999).

R.S. Means Co., Inc. Means Building Construction Cost Data, $57^{\text {th }}$ Annual Edition (Kingston, MA: R.S. Means Co., Inc., 1999).

R.S. Means Co., Inc. Means Electrical Cost Data, $22^{\text {nd }}$ Annual Edition (Kingston, MA: R.S. Means Co., Inc., 1999)

R.S. Means Co., Inc. Means Graphic Construction Standards (Kingston, MA: R.S. Means Co., Inc., 1986).

R.S. Means Co., Inc. Means Interior Cost Data, $16^{\text {th }}$ Annual Edition (Kingston, MA: R.S. Means Co., Inc., 1999).

R.S. Means Co., Inc. Means Mechanical Cost Data, $22^{\text {nd }}$ Annual Edition (Kingston, MA: R.S. Means Co., Inc., 1999).

R.S. Means Co., Inc. Means Plumbing Cost Data, $22^{\text {nd }}$ Annual Edition (Kingston, MA: R.S. Means Co., Inc., 1999).

R.S. Means Co., Inc. Means Residential Cost Data, $18^{\text {th }}$ Annual Edition (Kingston, MA: R.S. Means Co., Inc., 1999).

R.S. Means Co., Inc. Means Sitework and Landscape Cost Data, $18^{\text {th }}$ Annual Edition (Kingston, MA: R.S. Means Co., Inc., 1999).

R.S. Means Co., Inc. Means Square Foot Costs, $20^{\text {th }}$ Annual Edition (Kingston, MA: R.S. Means Co., Inc., 1999).

Ruegg, Rosalie T., Peterson, Stephen R., and Marshall, Harold E. Recommended Practice for Measuring Life-Cycle Costs of Buildings and Building Systems, Interagency Report 80-2040 (Gaithersburg, MD: National Institute of Standards and Technology, June 1980).

Whitestone Research. The Whitestone Building Maintenance and Repair Cost Reference 1999 (Santa Barbara, CA: Whitestone Research Corporation, 1999). 
UNIFORMAT II Classification of Building-Related Sitework (E1557-97)

\begin{tabular}{|c|c|c|}
\hline $\begin{array}{c}\text { Level } 1 \\
\text { Major Group Elements }\end{array}$ & $\begin{array}{c}\text { Level } 2 \\
\text { Group Elements }\end{array}$ & $\begin{array}{c}\text { Level } 3 \\
\text { Individual Elements }\end{array}$ \\
\hline \multirow[t]{5}{*}{ G BUILDING SITEWORK } & G10 Site Preparation & $\begin{array}{ll}\text { G1010 } & \text { Site Clearing } \\
\text { G1020 } & \text { Site Demolition and Relocations } \\
\text { G1030 } & \text { Site Earthwork } \\
\text { G1040 } & \text { Hazardous Waste Remediation } \\
\end{array}$ \\
\hline & G20 Site Improvements & $\begin{array}{ll}\text { G2010 } & \text { Roadways } \\
\text { G2020 } & \text { Parking Lots } \\
\text { G2030 } & \text { Pedestrian Paving } \\
\text { G2040 } & \text { Site Development } \\
\text { G2050 } & \text { Landscaping } \\
\end{array}$ \\
\hline & G30 Site Mechanical Utilities & $\begin{array}{ll}\text { G3010 } & \text { Water Supply } \\
\text { G3020 } & \text { Sanitary Sewer } \\
\text { G3030 } & \text { Storm Sewer } \\
\text { G3040 } & \text { Heating Distribution } \\
\text { G3050 } & \text { Cooling Distribution } \\
\text { G3060 } & \text { Fuel Distribution } \\
\text { G3090 } & \text { Other Site Mechanical Utilities }\end{array}$ \\
\hline & G40 Site Electrical Utilities & $\begin{array}{ll}\text { G4010 } & \text { Electrical Distribution } \\
\text { G4020 } & \text { Site Lighting } \\
\text { G4030 } & \text { Site Communications \& Security } \\
\text { G4090 } & \text { Other Site Electrical Utilities } \\
\end{array}$ \\
\hline & G90 Other Site Construction & $\begin{array}{ll}\text { G9010 } & \text { Service and Pedestrian Tunnels } \\
\text { G9090 } & \text { Other Site Systems \& Equipment }\end{array}$ \\
\hline
\end{tabular}

